Florida International University FIU Digital Commons

$11-9-2012$

\title{
Wage Matters \& Globalization: South Florida's Low-Wage Immigrant Plant Nursery Workers and Business Protectionism in the Age of Neoliberalism
}

Alejandro Angee

Florida International University, aange001@fiu.edu

DOI: $10.25148 /$ etd.FI12120512

Follow this and additional works at: https://digitalcommons.fiu.edu/etd

\section{Recommended Citation}

Angee, Alejandro, "Wage Matters \& Globalization: South Florida's Low-Wage Immigrant Plant Nursery Workers and Business Protectionism in the Age of Neoliberalism" (2012). FIU Electronic Theses and Dissertations. 783.

https://digitalcommons.fiu.edu/etd/783 


\section{FLORIDA INTERNATIONAL UNIVERSITY \\ Miami, Florida}

\section{WAGE MATTERS \& GLOBALIZATION: \\ SOUTH FLORIDA'S LOW-WAGE IMMIGRANT PLANT NURSERY WORKERS AND BUSINESS PROTECTIONISM IN THE AGE OF NEOLIBERALISM}

A dissertation submitted in partial fulfillment of the requirements for the degree of DOCTOR OF PHILOSOPHY

in COMPARATIVE SOCIOLOGY by Alejandro Angee 2012 
To: Dean Kenneth G. Furton

College of Arts and Sciences

This dissertation, written by Alejandro Angee, and entitled Wage Matters \& Globalization: South Florida's Low-Wage, Immigrant Plant Nursery Workers and Business Protectionism in the age of Neoliberalism, having been approved in respect to style and intellectual content, is referred to you for judgment.

We have read this dissertation and recommend that it be approved.

Liliana Goldin

Guillermo Grenier

Alex Stepick, Major Professor

Date of Defense: November 9, 2012

The dissertation of Alejandro Angee is approved.

Dean Kenneth G. Furton College of Arts and Sciences

Dean Lakshmi N. Reddi University Graduate School

Florida International University, 2012 


\section{DEDICATION}

This work is dedicated to the memory of my parents and the eleven brothers and sisters they gave me. Without their dedication to my education, none of these pages would have ever been written. 


\section{ACKNOWLEDGMENTS}

I wish to thank the members of my committee for their support, patience, and dedication. Their guidance has been incredibly valuable, especially during times of anxiety and uncertainty in the process of crafting my research and writing this dissertation. I would like to thank Dr. Bruce Nissen for his insight in issues of labor and labor relations; Dr. Liliana Goldin for incentivizing me to write about current modes of global transformations; Dr. Guillermo Grenier for his fun and effective approach to teaching and applying sociological theory; and my committee chair, Dr. Alex Stepick for sharing his immense knowledge of migration issues as well as for his emotional support and intellectual supervision in the creation and completion of this academic endeavor.

I also want to thank Carol Dutton Stepick who gave me an immeasurable amount of emotional support by comforting me in times of distress and encouraging me in every step of the way. In addition, I would like to thank Cynthia Selene Hernandez for her support in and out of the field, where she worked intensely in recruiting informants for this dissertation, organizing and analyzing data, and in co-writing academic articles that emerged from the research here presented.

Finally, I would like to acknowledge the research Institute on Social and Economic Policy (RISEP) at Florida International University and their staff. RISEP provided me with the research assistantship which set me on the path to studying labor conditions in the Florida plant nursery industry and gave me the support, tools, and confidence to complete this dissertation. 


\title{
ABSTRACT OF THE DISSERTATION
}

WAGE MATTERS \& GLOBALIZATION:

\section{SOUTH FLORIDA'S LOW-WAGE IMMIGRANT PLANT NURSERY WORKERS AND} BUSINESS PROTECTIONISM IN THE AGE OF NEOLIBERALISM

by

\author{
Alejandro Angee \\ Florida International University, 2012 \\ Miami, Florida \\ Professor Alex Stepick, Major Professor
}

Ornamental plant production in the State of Florida is an anomaly with respect to current theories of globalization and particularly their explanation of the employment of low-wage, immigrant labor. Those theories dictate that unskilled jobs that do not need to be performed within highly developed countries are outsourced to where labor is cheaper and more flexible. However, the State of Florida remains an important site of ornamental plant production in the US amidst a global economic environment of outsourcing and transnational corporate expansion. This dissertation relies on 50 semistructured interviews with insiders of the Florida plant nursery industry, focus groups, and participant observation to explain how US trade, labor, and migration policy-making at local levels are not removed from larger global processes taking place in the world since the 1970s. In Florida, elite market players of the plant nursery industry have been able to resist global trends in free trade, operating instead in a protected market. They have done this by appealing to scientific justifications and through arbitrary implementations of neoliberal ideology that keeps small and middle range business alive, while maintaining a seemingly endless supply of marginalized and exploited lowwage, immigrant workers. 


\section{TABLE OF CONTENTS}

CHAPTER

PAGE

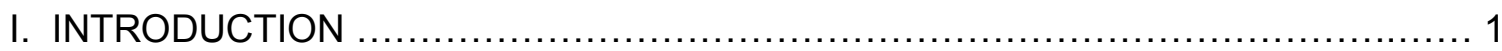

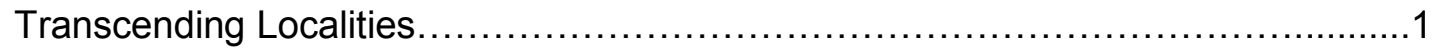

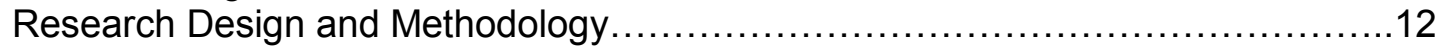

Research Setting, Sample and Data Sources...................................... 21

Confidentiality, Safety of Data, and Human Subjects Protection................... 25

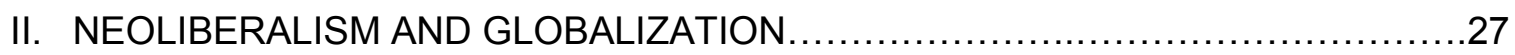

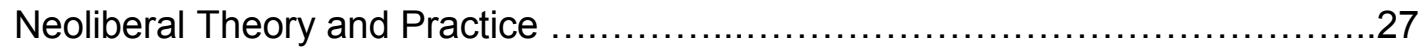

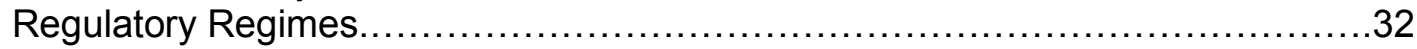

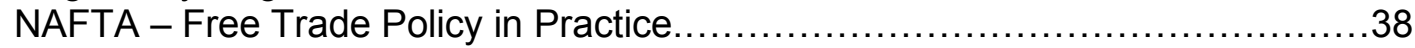

Trade Regulation in a Sea of Free Trade .......................................42

Neoliberal Restructuring and the Reorganization of Labor in the U.S. ................44

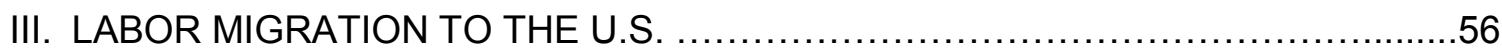

U.S. Labor Migration and Immigrant Incorporation............................... 57

Immigration Policy and Regulation in the U.S. ................................... 64

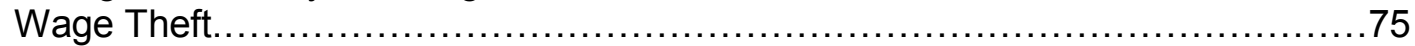

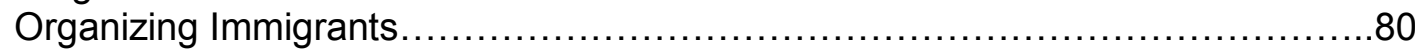

IV. MAPPING OUT THE FLORIDA GREEN INDUSTRY $\ldots \ldots \ldots \ldots \ldots \ldots \ldots \ldots \ldots \ldots \ldots$

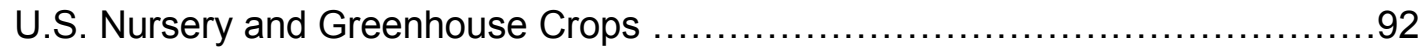

Florida Nursery and Greenhouse Crops......................................... 93

Impacts and Characteristics of the Florida Nursery Industry Labor Force..............95

Size of Florida Firms............................................................. 99

Sales Trends for Florida Floriculture and Nursery Crops........................ 100

Industry Structure and the Commodity Chain in Florida......................... 104

V. DEREGULATION IN FLORIDA'S PLANT NURSERY PRODUCTION $\ldots \ldots \ldots \ldots \ldots 121$

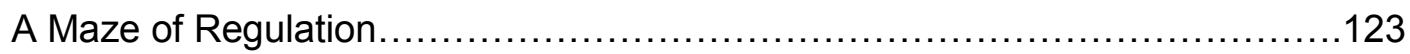

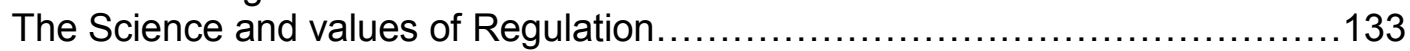

Political Arrangements, Interest Groups and Resistance of Traditional Firms.....143

Bonds of Dependency and the Formation of Regulatory Regimes...............148

Neoliberal Winds: Inconsistency and Opportunism ........................... 152

VI. PLANT NURSERY WORK IN FLORIDA: LIFE ON THE MARGINS $\ldots \ldots \ldots \ldots \ldots \ldots 161$

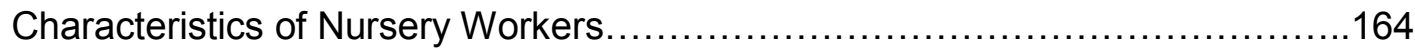

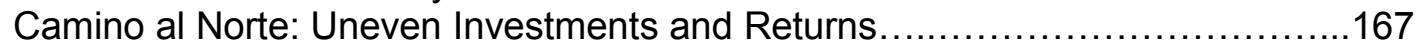

Worker Conditions and Vulnerabilities..................................... 179

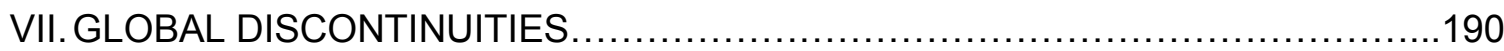

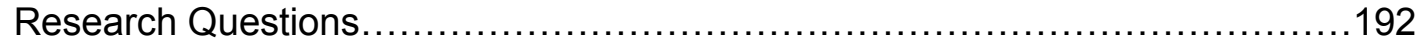

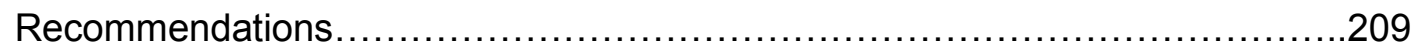

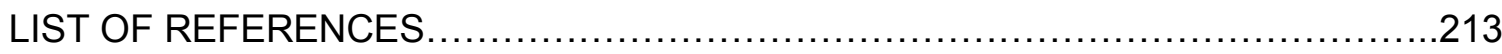




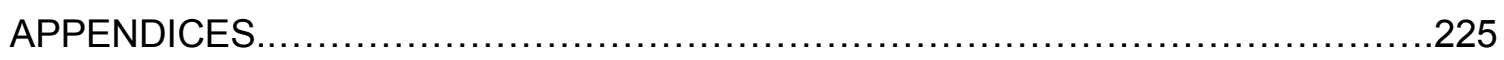

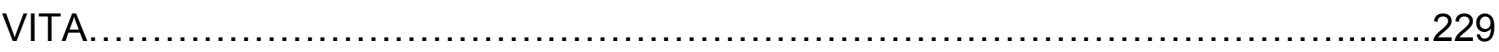




\section{LIST OF FIGURES}

FIGURE

PAGE

1. Florida Greenhouse and Nursery Crops: Value of sales 2000 to 2010.

2. Greenhouse use reported by respondents of the Economic Impacts of the Florida Environmental and Horticulture Industry Study

3. Container and field nursery area use reported by respondents of the Economic Impacts of the Florida Environmental and Horticulture Industry Study.

4. Distribution of horticultural industry sales by market region reported by respondents of Economic Impacts of the Florida Environmental and Horticulture Industry Study. ...

5. Distribution of nursery and greenhouse product sales by type of customer reported by respondents of the Economic Impacts of the Florida Environmental and Horticulture Industry Study. ...

6. Market Structure and Economic Linkages of the Green Industry..................105

7. Configuration of Florida's Plant Nursery Industry Elite........................... 123

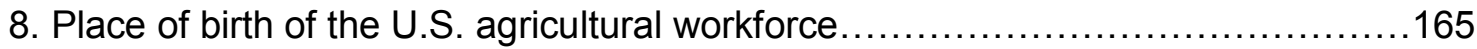

9. Employment eligibility of the foreign born agricultural population...................165 


\section{ACRONYMS AND ABBREVIATIONS}

\begin{tabular}{|c|c|}
\hline AFL-CIO & $\begin{array}{l}\text { American Federation of Labor and Congress of Industrial } \\
\text { Organizations }\end{array}$ \\
\hline ANLA & American Nursery and Landscapers Association \\
\hline APHIS & Animal Plant Health Inspection Service \\
\hline BPAI & Bureau of Plant \& Apiary Inspection \\
\hline COLA & Cost of Living Adjustment \\
\hline DHS & Department of Homeland Security \\
\hline DOL & Department of Labor \\
\hline DPI & Division of Plant Industry \\
\hline FDOT & Florida Department of Transportation \\
\hline FIU & Florida International University \\
\hline FLSA & Fair Labor Standards Act \\
\hline FNGLA & Florida Nursery Growers and Landscapers Association \\
\hline GATT & General Agreement on Trade and Tariffs \\
\hline IFAS & Institute of Food and Agricultural Sciences \\
\hline IRCA & Immigration Reform and Control Act \\
\hline IIRIRA & Illegal Immigration Reform and Immigrant Responsibility Act \\
\hline NAFTA & North American Free Trade Agreement \\
\hline NAICS & North American Industry Classification System \\
\hline NASS & National Agricultural Statistics Service \\
\hline NAWS & National Agricultural Workers Survey \\
\hline NLRA & National Labor Relations Act \\
\hline NLRB & National Labor Relations Board \\
\hline PPA & Plant Protection Act \\
\hline$P P Q$ & Plant Protection and Quarantine \\
\hline
\end{tabular}




$\begin{array}{ll}\text { SPS } & \text { Sanitary and Phytosanitary } \\ \text { RISEP } & \text { Research Institute on Social and Economic Policy } \\ \text { UF } & \text { University of Florida } \\ \text { UFW } & \text { United Farm Workers of America } \\ \text { USCIS } & \text { U.S. Citizenship and Immigration Service } \\ \text { USDA } & \text { United States Department of Agriculture } \\ \text { USDOL } & \text { United States Department of Labor } \\ \text { WTO } & \text { World trade Organization }\end{array}$




\section{INTRODUCTION}

\section{Transcending Localities}

Late in 2011 the state of Alabama passed the United States' harshest contemporary anti-immigration law in an effort to drive away large numbers of undocumented immigrants residing in that state. As the New York Times editorial titled "It's What they Asked For" reported, the move sought to reach what some of its proponents described as "attrition through enforcement," in a strategy where expensive police-state roundups would be eliminated by making the life of undocumented immigrants hard enough so that they would leave on their own (October 19, 2011). According to the editorial, the Alabama legislature followed the lead of Arizona which had implemented a similar law, and included provisions that gave local police enforcement the right to ask about the immigration status of individuals, forced public universities to deny admittance to undocumented immigrants, sought to determine the immigration status of public school students and to measure their economic impact to the state, made the transportation of undocumented immigrants a crime, and prohibited renting housing to undocumented immigrants. But the law presented residents of the state with an array of unintended consequences, particularly for farmers who within days of the law's passage were already reporting an exodus of their farm labor and a shortage of hands to pick the harvests across the state.

The passing of the Alabama and Arizona anti-immigration laws brings to light a plethora of issues that lie at the front of America's social structures and institutions. At a normative level, the laws demonstrate that a variety of racial and ethnic conflicts that have affected the country's history are still alive in the collective conscience of a nation that has for so long battled over the inclusion of ethnic minorities into its national identity. At a structural level the laws demonstrate the ways in which policy makers and the 
general public often fail to recognize the broader political, economic, and cultural dimensions associated with the movement of people across international borders and the implications that this process has for a variety of actors across class, racial, ethnic, political, and geographic boundaries.

To many observers, the conditions highlighted by the passage of such harsh antiimmigrant laws respond to issues that are of national or "domestic" nature, but in actuality are embedded in a variety of relations and dependences which are often transnational or global in scope and which require a deeper examination of the collective attitudes and institutional arrangements from which they emerge. The issue of dependence was promptly observed In the case of Alabama when even in a period of steep unemployment the state's farmers had a difficult time filling those jobs left behind by the exodus of immigrant laborers. Policymakers ignored a variety of relationships between the farming entrepreneurs, their workers and the worker's communities, and the dependence that the U.S. as a whole has created and maintained for foreign labor. This dissertation demonstrates and documents some of those manifold links for the case of the plant nursery industry in Florida.

In this manuscript I argue that U.S. trade, labor, migration, and policy making at the state levels are not removed from the larger global processes taking place in the world since the 1970s. At the core of these processes are market players and rules that benefit sets of powerful actors over others and which often result in the marginalization and exploitation of less powerful individuals such as workers and immigrants. But the ways in which these configurations take place at the level of particular U.S. states vis-àvis that of independent nations have often been ignored by the literature on globalization. Such an omission provides an important link to understanding how the processes of global transformation work, especially since decision-making may be 
embedded in lower levels of governance or dictated by the interactions and deeds of actors that are removed from the federal level of policy making.

Traditional views of the process of globalization taking place in the world since the 1970s often describe the process as the transformation of capitalism through international trade regulations that benefit the world's powerful corporations through a process by which technology and communication shift sites of production to areas where labor is "cheaper" and more flexible (see for example Greider 1998, Stiglitz 2002, Harvey 2005, Glyn 2006). Such understandings of globalization have also been complemented by cultural theories that promote an evolutionary view of globalization, and which focus on global reproductions and re-configurations of new forms capital, labor and technologies (Tsing 2005). Such monolithic views have come to dominate the academic readings and popular perceptions about globalization with narrow definitions that essentialize globalization as a one-way process in which labor and the environment in peripheral sites are transformed by the direct efforts of powerful actors in the developed world. But what, if any, implications arise from traditional forms of capitalist production in localities at the core within the context of current global economic tendencies? How are processes of globalization affecting and affected by social interactions and institutional arrangements at these non-peripheral sites? And what contributions can social scientists make to current theories of globalization about the patterns of socio-economic globalization taking place in developed countries?

In this document I focus on the idea that globalization, rather than being a one way process, is a process of multiple dimensions, directions, and outcomes that operate in rather discontinuous scales, conditions, and time frames. I focus on the idea that beneath those observable patterns and trends globalization "is about relations of relative power, dependence as much as exchange, and how otherness becomes naturalized or 
provokes resistance;" thus, far from being simply a technical matter, globalization is deeply embedded in political processes (Tabb 2001; 13). In this sense, globalization is said to be mediated by a process of governance networks that potentially operate from the local to the transnational and which require a variety of social mechanisms to enforce contracts and standards of judging what is considered permissible behavior by participants.

I argue that processes of governance shed light on how decisions made by a variety of actors influence the degree to which global configurations of trade, labor, capital, culture, ethnicity, and class are produced or reproduced in localities of the developed world. In other words, it is the analysis of a variety of interactions between influential actors and their relationship to less and more influential groups, which reveals the processes of globalization occurring in the world today. Thus, the differences in power relations and dependencies among economic elites, their workers, related governmental agencies, and policymakers are an essential theme to the work here presented.

For this reason, I follow Nader's $(1972 ; 289)$ call to anthropologists to "study up" as a way of understanding the processes whereby power and responsibility are exercised, while generating knowledge about those who shape attitudes and control institutional arrangements. As Nader argues, anthropology in the U.S. is filled with literature on the poor, the disadvantaged and minority groups, often neglecting to study the middle and particularly the upper classes. In this sense, Nader $(1972 ; 289)$ asks us to consider whether anthropologists should "study the colonizers rather than the colonized, the culture of power rather than the culture of the powerless, the culture of affluence rather than the culture of poverty." These questions are of particular importance to this manuscript, and as Nader contends, it is appropriate to study the bureaucratic institutions in the United States because such institutions and their network systems 
affect the people that anthropologists have traditionally been concerned with all around the world.

To this end I focus on the state of Florida and its vast plant nursery industry, where the state's subtropical climate and warm temperatures enable the year-round production of ornamental plants often without the use of greenhouses. But the issue of climate is only secondary to the development of the industry in the state, where the majority of plants are grown under specific agricultural regulations that prohibit any nursery stock, plants, roots, seeds, and other plant products from being imported into the country (United States Department of Agriculture, Plant Protection Act). ${ }^{1}$ This form of agricultural regulation has prevented the plant nursery industry from relocating overseas and from reshaping its nature into one of mere brokerage or distribution as has been the case with most of the cut flowers and ferns sold in the U.S today. However, at a deeper level, the plant nursery industry must rely on a legislative authority that protects it from foreign competition, even under current trends of trade liberalization agreements with neighboring Mexico, Colombia, Canada, and a variety of other nations.

At the same time that legislation has protected US production of nursery plants, the industry has come to depend on an imported low-wage, flexible, immigrant workforce for a variety of tasks that range from cleaning, packing, and fumigating, to more traditional agricultural functions associated with planting and maintaining the shrubs and foliage. Many of these workers are marginalized by their legal status, as well as by a variety of economic trends that have helped to diminish conditions for workers in the United States while weakening those organizations and institutions designed to protect them. This

\footnotetext{
${ }^{1}$ The Plant Protection Act (PPA) became law in June 2000 as part of the Agricultural Risk Protection Act. This law consolidates all or part of 10 existing U.S. Department of Agriculture (USDA) plant health laws into one comprehensive law, including the authority to regulate plants, plant products, certain biological control organisms, noxious weeds, and plant pests. http://www.aphis.usda.gov/brs/pdf/PlantProtAct2000.pdf
} 
process is embedded in a variety of global, regional, and local contexts that have largely intensified within the context of the neoliberal restructuring process of the last three decades (see Greider 1998, Stiglitz 2002, Harvey 2005, Glyn 2006 for a description of structural changes within the context of neoliberal restructuring of the last three decades). In the case of Florida's plant nursery industry, an anomaly with respect to current theories of globalization and particularly their explanation of the employment of low-wage, immigrant labor seems to emerge. Specifically, since those theories indicate that unskilled jobs that do not need to be performed within the most highly developed countries are outsourced to where labor is cheaper and more flexible (see Greider 1998, Stiglitz 2002, Harvey 2005, Glyn 2006). Thus, cheap and specifically immigrant labor is required in developed countries only for the work that is place bound, such as cleaning of office buildings, and highly perishable agricultural goods. In theory, however, nursery plants could be grown more "efficiently," that is with lower production costs, in many other countries, such as is the case with much of the cut flowers sold in the U.S.; yet, nursery plant production remains strong in the state, demanding that a large labor force is mobilized to supply low-wage labor to U.S. plant nursery employers.

In several ways, this dissertation looks at globalization from the ground up. Rather than concentrating on powerful corporate actors and their expansion of power and dominance around peripheral sites, I look at a variety of local actors, interactions and processes embedded in regions of the developed world. In this sense, I argue that power relations at local levels produce new forms of institutional arrangements across a variety of economic, racial, political, and institutional levels that are transnational and global in scope. To this end, I concentrate on a variety of groups hierarchically positioned within Florida's plant nursery industry, ranging from the political elites, the state's governing regulatory agencies, and plant nursery producers to the low-wage 
immigrant workers who do the manual labor in farms throughout the state. Specifically,

in this manuscript I seek to answer:

- Why and how has Florida remained one of the most important sites of nursery plant production for the U.S. market amidst neoliberal economic restructuring of the last 3 decades that has generally moved commodity production from the U.S. to developing countries where it is deemed more efficient and less expensive to produce? And, how must current theories of globalization be adjusted to account for South Florida's large nursery trade?

- What are the implications for the large, immigrant labor force of the plant nursery industry in terms of working conditions, rights, and benefits? And do labor-migration theories accurately account for current processes of globalization or do these theories also represent an anomaly in their relationship to policy implementation within the plant nursery industry?

I first got involved with the plant nursery industry in 2007 when as a graduate student at Florida International University (FIU) the opportunity arouse for me to study the frequency and extent of wage and hour abuses in a variety of towns in the state of Florida. The opportunity presented itself thanks to the work performed by the Research Institute on Social and Economic Policy (RISEP) at FIU, which is dedicated to serving social justice organizations in the state of Florida with empirical research on significant issues relevant to low- and moderate-income families and individuals. As part of a broad, statewide campaign to combat wage theft and other forms of wage abuses, I had the opportunity to get involved in the actions of several organizations that depended on RISEP for research and which worked together with the research institute to improve the working conditions of Florida workers. The experience resulted in my direct participation in and support to a variety of local organizations, which, later acted as gatekeepers to plant nursery workers and officials that proved quite valuable for the research here presented.

Since the summer of 2007 , I spent time in the offices of WeCount!, a community organization in Homestead that actively sought to help their members collect unpaid 
wages from their employers as part of their overall organizing strategy. Homestead, is the epicenter for most of south Florida's food and ornamental agriculture and is home to large immigrant communities of Mexican and Guatemalan agricultural workers. As part of my original research of wage and hour violations and wage theft, I documented the cases that many of the area's nursery workers were seeking to resolve through the help of WeCount! I also attended County commission meetings that pertained to worker issues, and I was able to meet many political and organizing figures who were in one way or another related to the plight of the workers.

In turn, the process led me to meet a variety of industry players who ranged from workers to community organizers and public officials, who were in one way or another victims or investigators of the kinds of abuses that were allegedly taking place within the industry. During this time, I also met a variety of individuals whose lives were embedded in very marginal spaces of class, labor, and migration. Many of these men and women were immigrants from the global south, specifically Mexico and Guatemala, who had come to the U.S. in search of a piece of the "American Dream," but who seemed to me to be living in the geographical and cultural margins of a society that knew little about them and which did not acknowledge the reasons for their presence.

As I delved deeper into the fabric of plant nursery production and of the community dynamics taking place in its surrounding areas I discovered that many of the assumptions about globalization and labor migration that I had learned in graduate school did not match the kinds of processes taking place at the ground level; specifically, theories that viewed that globalization as a linear process where multinational corporations expand to productions sites in the developing world in search of efficiency and profitability. This led me to question the process by which immigrants come to the state of Florida in search of jobs in the plant nursery industry and into the ways in which 
regulation and process work to influence their migration, their economic and labor integration, their fragile permanence and their marginality. Ultimately my questioning led me to "look up" at the industry with an institutional focus on how those structural processes are actually formulated and institutionalized. I knew that the focus of my work needed to be the workers, their strife, and what I perceived to be their marginalization, but I felt compelled to address the institutional arrangements associated with the industry's elites.

Early on I recognized that the federal government's regulation of agriculture fundamentally protected plant nursery production in the U.S. Unlike food agriculture, plant nursery production largely produces ornamentals that are not highly perishable and thus can be produced in other areas of the world. However, a strongly maintained regulatory system ensures that no planted organisms or soil are imported into U.S. grounds. Such prohibition protects U.S.-based producers of ornamental plants, but it also makes them dependent on low wage labor, which in the U.S. is primarily immigrant labor. This type of regulation holds the key for a system that in many ways defies the notions about globalization that have become embedded in public and academic discourses while also serving as the justification for a system that enforces old and new marginalization and alienation of immigrant laborers who are often rendered voiceless by those political and economic structures that benefit from their labor.

To address some of my major questions, in chapter two I discuss the literature and theory on neoliberalism and globalization with an emphasis on: (1) the contradictions in the implementation of neoliberal policies and the theories' basic premises; and, (2) the formation of regulatory regimes which produce new forms of legality to advance their own economic interests. In the chapter I argue that while neoliberalism centers on a framework of macroeconomic stabilization, trade liberalization, and the privatization of 
the economy (Harvey 2005; Clarke 2005; Munck 2005Fernandez-Kelly 2007), neoliberal policymakers have had to shift from theoretical foundations toward an application characterized by inconsistency and opportunism (Clarke 2005). These inconsistent applications arise from neoliberalism's emphasis on the individuality of rights and freedoms, accountability, and entrepreneurship, which contradict the desire for significant forms of collective life (Harvey 2005).

In addition, I discuss how the resilience, adaptation, and reproduction of traditional industries and business groups are centrally related to economic incentives and market conditions that are politically arranged, and which can be observed in the state's willingness to overlook labor violations of social security, minimum wage, and working conditions. These relationships are forged by values, norms and expectations which groups in society hold and which result in political decisions to protect the role and function of the traditional firm (Berger and Piore 1980). This discussion will bring to light how other forms of cultural and economic trends help to produce discontinuities in the processes of globalization that are driven by a variety of non-corporate, nontransnational actors in localities of the developed world.

Chapter three presents the literature and theory on immigration, and specifically on the modes of incorporation of low wage labor immigrants to the U.S. economy. In addition, the chapter presents a look at what many scholars interpret to be the use of U.S. immigration policy as a deliberate attempt to provide some employers with a nearly endless labor supply of a low-wage, vulnerable, un-organized labor force. In the chapter I review the literature on the adverse conditions experienced by low-wage workers in the U.S., arguing that the process of U.S. bound labor migration is the result of neoliberal trends that create a demand for this type of workers in a variety of localities and contexts 
of core countries despite large unemployment rates and decreasing modes of manufacturing and production.

Chapter four presents an overview of the Plant Nursery industry in the State of Florida, including a detailed explanation of the industry and its importance to the livelihood of thousands of immigrant workers as well as a significant contributor to the state economy. In this context I will present the industry in terms of economic impacts, labor impacts, the characteristics of the labor force, and the types of crops produced. This chapter includes an in-depth look at the industry based on reports and official data available and supplemented by some of my interviews, setting up the rationale and theoretical importance in how the industry and its location demonstrate those discontinuities in neoliberal restructuring that I engage in this manuscript.

Chapter five presents my research findings in relation to the main research question of how Florida has remained a strong site of local plant nursery production despite a strong shift toward free trade in a variety of U.S. industries. First, the chapter will focus on the way in which contradictions of the application of free trade manifest themselves in the State and are negotiated by State actors such as the Department of Agriculture and the local producers. Second, the relationship between State players and private actors is analyzed with a focus on the formation of regimes that affect policymaking to advance their particular business interests.

Chapter six seeks to answer my second research question regarding the implications for the immigrant labor force of the Florida Plant nursery industry. This section will describe my findings in terms of how the adverse conditions that the local labor force may face including, wages, benefits, rights, and labor conditions. I want to demonstrate that the plant nursery labor force faces similar conditions to those experienced generally by low wage workers of the U.S. economy as reported in the literature. To describe 
Florida's plant nursery workers' labor conditions, I will rely on ethnographic data from my original research with plant nursery workers.

I complete this dissertation with a discussion of the theoretical and empirical links between the regulated nature of the industry, its strong political organization, and the implications these have in terms of power imbalance and marginalization for the workforce. In addition, I will provide suggestions for future research.

\section{Research Design and Methodology}

As I argued above, it could be argued that from a neoliberal perspective nursery plants could be grown more "efficiently," that is with lower production costs, outside the U.S., as is the case with much of the cut flowers sold in the U.S. Yet, despite economic prescriptions that would project a "withering away" of plant nursery production in the U.S., the industry has remained strong in specific areas of the country such as California, Florida and Texas. Such anomaly can be explained by theories that highlight: (1) political arrangements that are forged by values, norms and expectations of interest groups in society in efforts to protect the role and function of traditional firms (Berger and Piore 1980); (2) how in search for pragmatism, neoliberal policymakers have had to shift from theoretical foundations toward an application characterized by inconsistency and opportunism (Harvey 2005); and (3), the way in which political and economic elites are related in mutual bonds of dependency, allowing them a high degree of political leverage and contributing to the formation of regulatory regimes (Rapley 2004). These trends have important implications for the immigrant labor force required for plant nursery production and which must deal with vulnerabilities associated with aspects of immigrant incorporation, immigration policy, human capital, and exploitation through wage theft as well as through the denial of rights and benefits. With these considerations, this research addresses the following questions: 
1. Why and how has Florida remained one of the most important sites of nursery plant production for the U.S. market amidst neoliberal economic restructuring of the last 3 decades that has generally moved commodity production from the U.S. to developing countries where it is deemed more efficient and less expensive to produce? And,

2. How must current theories of globalization be adjusted to account for South Florida's large nursery trade?

3. What are the implications for the large, immigrant labor force of the plant nursery industry in terms of working conditions, rights, and benefits? And,

4. Do labor-migration theories accurately account for current processes of globalization or do these theories also represent an anomaly in their relationship to policy implementation within the plant nursery industry?

In this section, I describe the research methodology for this dissertation, including the population, sample, data collection and analysis, as well as issues associated with confidentiality of data, and research limitations. The scope of work detailed in this section was designed to follow a two step research strategy. The first stage consists of building a profile of the nursery industry through archival research, and other secondary data sources. The second stage focuses on interviews performed on a sample of workers and elite members of the South Florida Plant Nursery Industry. In the manuscript I use industry elites to refer to members of the industry who are not laborers and who have in one way or another power within and insider knowledge of the plant nursery industry. This denotation thus includes owners and operators (also referred to as producers), professional association representatives, lobbyists, scientific regulators, and other industry insiders from banking and related agricultural businesses.

\section{$\underline{\text { Research Strategy }}$}

The data collection process for this dissertation was designed to pursue a two step research strategy. Data collection for the first stage (S1) took place over a six-month period. During this time, I collected and analyzed a variety of secondary and archival data sources including a search of government and industrial data and reports. For the 
most part, that meant data and information that could be accessed through the web or through the services of the FIU library system, which is part of the larger University of Florida library system. In order to uncover data and research available on the Florida Plant Nursery industry and specifically about industry structure, status, and commodity chain I turned to a wide variety of secondary data sources. I began with a search of government and industrial data and reports. I sought relevant data from the national and state level down to the county level through the 2007 Survey of Agriculture in order to get an idea of volume of sales in the industry at both the state and county levels and the size of the industry in the state of Florida, and in the relevant counties of Miami-Dade, Orange, and Lake; as well as information on the demographics of employers and employees. While my search through the 2007 Survey of Agriculture yielded valuable information at the state and county levels in relation to nursery size, sales volumes, and demographic characteristics of operators, the search yielded no information on the gender or ethnic/racial characteristics of the industry's labor force.

I also performed an extensive search through company and industry ally websites for relevant information including annual reports, biographies of top executives, product descriptions, and other information, which help to identify major finance mechanisms, players, and brokers. Also, for information on a subsample of the largest companies I searched Dun and Bradstreet Directories, which have limited information on private as well as public companies.

Finally, I conducted a search of news articles in the print media of Florida. I did this through Lexis-Nexis: Academic, which is readily available through the University of Florida library system. From this search I expected to find what practices, facts and public perceptions have been reported about the industry, but most articles concentrate 
on particular popular plant types, or more social/community related activities of industry players.

Following these searches, I utilized the largest statewide trade organization, the Florida Nursery, Growers, and Landscape Association (FNGLA), and its local chapter in Orange and Lake Counties (a combined chapter) and in Miami-Dade County. Both chapters publish newsletters and have extensive contact information for their large membership of growers. I found the FNGLA to be open and helpful and a valuable source of information about marketing and commodity chains. My most significant sources of information were a variety of surveys and reports produced by industry associations and industry-related research groups. These include articles and reports produced by the University of Florida Institute of Food and Agricultural Sciences (IFAS), articles in scholarly journals such as the Journal of Environmental Horticulture, and articles in trade publications such as American Nurseryman. I tried whenever possible to update outdated reports and article information through the use of the 2007 Survey of Agriculture, the Agency for Workforce Innovation, and through the Florida Research and Economic database.

Despite the importance, recent growth, and interest in the Green Industry, there is very little information available at the national level regarding the industry's economic impacts (Hall, Hodges, and Haydu 2005). Although the USDA conducts regular nursery crop surveys to collect information at the grower level, data are often incomplete for some states and grower cash receipts reported do not reflect the broader economic impacts generated by this industry (Hall, Hodges, and Haydu2005). In addition, U.S. Census data are subject to similar limitations, including problems of low response rates and poor data accuracy, while local economic data maintained by State comptrollers is filled with misclassification errors and non-compliance on the part of industry 
participants. Recently, the Industrial Classification System (NAICS) has been developed to ensure more robust estimates; however, no data has proven to accurately capture the economic impact of the industry, including issues that are significant at the state level (Hall, Hodges, and Haydu2005).

My searches and conversations with industry professionals revealed that no study has been undertaken to describe the demographic characteristics of the industry's workforce; and, while the Census of Agriculture does collect demographic information on farm operators, it does not estimate demographic information for employees. In addition, to my knowledge, only one report highlights the working conditions and abuses faced by the workers of plant nurseries, but the study is specific to Miami-Dade County and I should exercise caution about generalizing these findings at the state level. Economic data collected by the census of Agriculture and a variety of industry analysis often separate the farm operations into a variety of categories such as Nursery Crops, Floriculture Crops, Green house Crops, or even Greenhouse and Nursery Crops; thus, making comparisons between years and regions very difficult in terms of size, profits, and types of crops of industry producers.

I also found it difficult to report nursery-specific labor and wage statistics, since information related to nursery workers are often aggregated with other kinds of agricultural farm workers and laborers. Thus, the information I report on labor and wages comes from articles and reports that sample segments of the industry, but there, too, I found discrepancies between reports, making the numbers at least speculative, and hard to generalize, making me highly skeptical about their accuracy.

To learn all that was needed for a full and detailed structural and commodity chain analysis of products from an industry with such diversified products and producers as the plant nursery industry, I turned to interviews with key industry players. These 
interviews were designed to uncover information not available through the often lacking secondary data sources.

Stage 2(S2), consisted of the acquisition and analysis of transcribed interviews from a sample of workers and elite actors. I define elite actors as those individuals who occupy positions of power within the industry and include nursery farm owners, lobbyists, and U.S. Department of Agriculture scientists and regulators. The Interviews with plant nursery workers included basic demographic questions about migratory status, language, education, gender, age, income, place of birth, and length of time in the country as well as open-ended questions inquiring about rights, benefits, the impact of wage theft among those who have been victimized, the conditions that preceded the northbound migration process, and the process of settlement and integration to the local culture and economy. Interviews with plant nursery elites included business information about trade and labor, industry pressures and competition, marketing, transportation, and employer-employee relations.

I interviewed a few key industry players to explicate gaps in the secondary data sources. These informants range from plant nursery employees/operators to industry specialists in commerce, trade, finance, or marketing. Through previous research in the plant nursery industry I have identified approximately 20 growers in Miami-Dade County who were willing to talk about the industry from their perspective and who could act as starting points for a variety of snowball samples. Snowball sampling has been proven to generate adequate variation when the number of starting points is multiple (Trost 1986; Chavez, McMullin, Mishra, and Hubbell 2001). I asked them for recommendations of key figures known to them and attempted to arrange interviews with them as well. Other recommendations for interviews were solicited from the local chapter of the Florida Nursery Growers and Landscape Association (FNGLA). 
The analysis of these interviews addresses the financing mechanisms and institutions used by nursery growers for land and supplies and for crop production, including government subsidy programs; the economic health of the industry as measured by profitability, percentage of market and other indicators according to availability of secondary data; the major competition - within the industry in Florida, and from national and international competitors; the real and perceived threats/challenges facing the FL nursery industry, including labor supply, health, safety and environmental regulations; the trends in the industry, for example, consolidation, increasing sales, wholesale vs retail (including on-line marketing, start-ups, buying habits of consumers; and, How nursery products get from the nursery to the consumer.

\section{$\underline{\text { Question } 1}$}

Why and how has Florida remained one of the most important sites of nursery plant production for the US market amidst neoliberal economic restructuring of the last 3 decades?

To answer this question I relied on information acquired through both steps of the research strategy. The first stage of this research strategy concentrated on a variety of third party papers, reports, and public statistics about the state of Florida's plant nursery industry. The results describe the structure of the industry with a focus on the main finance, marketing and transport mechanisms most generally used in and by nursery growers as well as the national and international status of the industry. It also outlines the commodity chain from producer to final consumers. This first stage thus, demonstrates the solidity of the Florida plant nursery industry within a national and international context. Next, I rely on my interviews with industry producers, regulators, lobbyists, and other industry insiders in order to focus on those institutional arrangements and social interactions that permit the plant nursery industry to remain 
strong in the state of Florida and highly competitive within a growing globalizing industrial environment.

Transcripts and field notes from interviews were entered into MAXQDA, a data management and analysis program, to identify ideas, patterns, descriptors, key words, and contextual information. I performed a systematic analysis of the transcribed interviews and the secondary data sources with a focus on the institutional arrangements that help to maintain the industry local and the structural conditions that may be at play behind regulation (e.g., values, norms, land attachment, profits, competition, business interests, traditional arrangements, competition, laws, etc.). In this step, I also created the commodity chain through the use of MAXQDA Maps, which allows the user to integrate and graph quantitative, qualitative, and secondary data sources in a graphic model in order to provide a detail picture of the structure of the industry and of the social interactions that are embedded in it.

\section{$\underline{\text { Question } 2}$}

How must current theories of globalization be adjusted to account for South Florida's large nursery trade?

For this question, I focused on the interviews with industry elites acquired in the second stage of the research strategy in order to address gaps in traditional neoliberal and globalization theory. I hypothesize that South Florida's nursery industry does not fit the predictions of globalization theory and the use of labor because of institutional arrangements that disallow competition from foreign-produced nursery products. Neoliberal theories predict that employers try to keep labor costs as low as possible; paying less than the legal minimum, for instance. However, free trade and neoliberal theories fail to explain how an industry can get away with breaking labor laws; or, how an industry such as South Florida's plant nurseries, can compete successfully against 
foreign competition where labor costs are likely to be even lower than those obtained by violating labor laws.

For this question I will rely on the analysis of transcripts and field notes from interviews through the use of MAXQDA, to identify those institutional industry arrangements that do not fit within the traditional frameworks postulated by existing neoliberal and globalization theories. To this end, I will analyze the discourses and policies of industry elites and observe if and how these fit traditional postulations of neoliberal theory and globalization presented in the forthcoming literature arguments.

\section{Question 3}

What are the implications for the large, "imported," labor force in terms of economic incorporation, working conditions, rights, and benefits?

The plant nursery industry in the state of Florida has come to rely heavily on low wage workers from the developing world. Thus, this is an essential component of this dissertation, as the conditions for workers are markedly different for those of industry elites. For this question I focus on the interviews collected on the second stage of research with industry elites and focus on the data collected with workers, employers and professionals of the plant nursery industry. Again, I rely on the analysis of transcripts and field notes from interviews through the use of MAXQDA, to identify how a variety of institutional arrangements impact the industry's use of immigrant labor. In addition, I compare and analyze the workers' and employers' answers to observe any patterns that may emerge in regards to migration, exploitation, marginalization, and other conditions embedded within the employer-worker relationship. In addition, data analysis for this question relies on field notes done during participant observation in the fieldwork phase of the dissertation at various localities of plant production. I hypothesize that despite a series of normative discourses from industry elites that promote inclusion and 
opportunity, the workers find themselves marginalized through a variety of policies and institutional arrangements that largely benefit the elite class.

\section{Question 4}

Are labor-migration trends in the industry consistent with current theories of globalization or do they represent an anomaly in their relationship to policy implementation?

For this question, I rely on my interviews with both industry elites and workers of the plant nursery industry gathered on stage 2 of the research plan. I analyze transcripts and field notes from interviews through the use of MAXQDA, to identify those institutional industry arrangements that do not fit within the traditional frameworks postulated by existing theories of migration. To this end, I analyze the discourses and policies of industry elites in relation to migration management, their views on the use of foreign born labor migrants and observe whether or not these fit traditional postulations of migration theory presented in the forthcoming migration literature argument. I also analyze how the views, values, and practical implementations of employers in regards to their foreign born labor force affect the broader policies that dictate and affect the movement of workers across international borders.

\section{Research setting, sample and data sources}

Miami-Dade County and the state of Florida are home to a lucrative plant nursery and landscaping industry. A 2006 report by the University of Florida's Institute of Food and Agricultural Sciences (UF/IFAS) places this industry second only to that of the state of California in terms of national industry value. Total sales of landscaping and nursery firms in the state averaged $\$ 15.2$ billion in 2005 , growing by approximately $54 \%$ since the year 2000 (Hodges and Haydy 2006). Overall, the industry provides close to 294,000 jobs, with about $65 \%$ of them being full-time positions. Miami-Dade County tops the list 
of sales, with an estimated $\$ 1.9$ billion in 2005 and a labor force of about 40,000 (Hodges and Haydy 2006).

The industry can be divided into three distinct segments, with nursery growers, landscape sales, and garden center retail sales being managed under similar conditions and often, under the same operation. The largest of these segments is garden center retail, which provides live plants, horticultural hard goods, and other supplies to garden centers and retailers throughout the country. Garden center retail was responsible for producing close to \$7 billion in sales in 2005 (Hodges and Haydy 2006). Landscape sales, the second largest segment, consists of installation, maintenance, and design of landscapes primarily for developers, office buildings, retail malls, and outdoor city projects. The landscape segment's total 2005 sales represented over $\$ 5$ billion (Hodges and Haydy 2006). Finally, nursery grower sales represent the third sales segment of the industry. This segment's sales in 2005 was about $\$ 3$ billion and consisted mainly of tropical foliage, shrubs, potted flowering plants, liners, trees, and turf-grass among others (Hodges and Haydy 2006).

It is often difficult to separate information pertaining to these three areas of industrial production; however, this dissertation focuses specifically on plant nursery production. In the literature floriculture and greenhouse production are synonymous and distinct from nursery crops, which are plants grown mostly out of doors in fields or containers. Nursery and floriculture/greenhouse production are the two sectors where most of the workers of concern to this study are concentrated within the larger complexly integrated and inter-reliant structure of the Green or Environmental Horticulture industry. In many cases, researchers combine both categories (nursery and floriculture or nursery/greenhouse) into a single analysis, while in many others the sectors are treated separately. In addition, industrial analyses often include or lump these two sectors with 
other large areas of the Green industry, such as retail, landscaping, re-wholesaling, as well as a variety of suppliers of seeds and raw materials for production and installation of green industry products. These industry sectors are highly interrelated; therefore, my look at industry structure and commodity chain contains many of these important sectors as well in order to situate and give a contextual comparison of the sectors of concern (greenhouse and nursery crops). For the purpose of this manuscript, I have separated greenhouse or floriculture and nursery crops whenever data is available for both types of horticultural production, but in most cases I treat them as a single sector depending on the availability of information and the sources which inform this study.

Interviews and participant observation for my dissertation took place in a variety of settings in the state of Florida. Employer interviews took place in the counties of MiamiDade, Orange, and Volusia which are important centers of plant nursery production. Interviews with industry elites, that is industry regulators, professional business representatives, and political actors were conducted in Miami-Dade County, Orange County, and Alachua County, which are important centers of economic, research, and political control of the industry. Interviews with Workers were conducted in Homestead in the southern tip Miami Dade County and home to a large community of immigrant farm nursery workers from the area's industry.

Interviews with workers and elites of the Florida plant nursery industry for this dissertation were conducted between the summer months of 2007 and the winter of 2010. My sample consists of 70 individuals who work within or are related to the plant nursery industry. The sample includes interviews with 40 plant nursery, low-wage, immigrant workers in Miami Dade County, a focus group of 10 workers with the same demographic characteristics, and 20 interviews with industry insiders, employers, professional representatives, and regulators of the industry located throughout the state 
of Florida. The sample of workers is made up of 35 Guatemalan workers, 13 Mexican, 2 Haitians, and one Puerto Rica. In terms of gender, the worker sample is made up of 15 females and 35 males. The 20 interviews with members of the industry's elite are made up of white non-Hispanics and contain only two females in banking and research positions that support the industry, who do not directly work within it.

Early attempts to access the workers often proved difficult, as they were often wary of strangers and individuals outside their ethnic/social networks. I was able to gain access to workers through local community organizations which serve the immigrant industry workers through a variety of services such as English classes, legal supports, housing, worker training, and leadership training related to community organizing. These organizations facilitated access to workers and served as entry points to commence multiple snowball samples. Previous collaborative efforts with faculty at Florida International University (FIU) had connected me with a variety of community organizations, facilitating entry points and access to their members for the initial snowball samples and continuous participant observation. These organizations leaders and organizers lead me to workers who were later contacted using a purposive sample, in which I used my knowledge of this specific group to select those informants with the necessary knowledge of the conditions experienced by workers of the plant nursery industry. Snowball samples allow the researcher to locate one or more key individuals and ask them to name other likely candidates for the research. For this reason, snowball sampling is very useful in studies of social networks, which may include elites and other bounded and difficult-to-find populations such as undocumented immigrants (Bernard 1988).

For operators, I selected a random sample from a list of plant nurseries provided to by the Florida Nursery, Growers and Landscape Association, (FNGLA); a great majority 
of these nurseries were members of the FNGLA. Most of the operators I contacted agreed to participate, except in some of the larger nurseries where access was controlled by receptionists and assistants who blocked contact with the individuals in management positions.

\section{$\underline{\text { Interviews }}$}

The interviews conducted were unstructured, in-depth, and open-ended. They sought to explore any political arrangements that disallow competition from foreignproduced nursery products as well as the relationship between the industry's labor needs and its use of low-wage, immigrant labor. Because my informants hold different industry positions and play different roles, the structure of each interview followed a different course of action. The interviews were recorded using a digital voice recorder, and then transcribed into text for further analysis (Appendix 1 shows the topic areas covered in the interviews).

\section{Confidentiality, Safety of Data, and Human Subjects Protection}

Protecting the identity of all research participants is a major responsibility of this research project. Many of the target participants were immigrants who are undocumented in the country. In addition many participants were vulnerable or fearful of employers who may have abused them in the past. As a result, no identifiable individual personal information was collected in this research project and informants' real identities will be concealed through the use of pseudonyms. All interviews and focus groups were recorded acoustically, and in the recording process only first names were used to identify participants.

All participants were provided a written copy of the research objectives, a description of risks and benefits, and the pertinent contact information of the researcher and the Institutional Review Board (IRB) at FIU. Spanish speaking participants were 
provided a Spanish version of all information (Guatemalans whose native language is Mayan were included in the sample only if they could communicate at least at a simple conversational level in Spanish). 


\section{NEOLIBERALISM AND GLOBALIZATION}

In this chapter I focus the global socio-economic transformations of the last three decades, emphasizing the role that neoliberal trends have played in the reconfiguration of traditional forms of capitalist production. In this context, I discuss the contradictory process embedded in the application of neoliberal policies, the formation of regulatory regimes needed to implement such policies, and the process by which traditional industries have been able to navigate through changes in the political economy of developed nations. I also provide an introduction to the concept of sanitary and phytosanitary policies in agriculture, emphasizing the way in which such regulations are problematic for the fulfillment of an international free trade agenda while exemplifying a series of discontinuities in the process of economic globalization. Finally, I discuss the decline in labor conditions in the U.S. and the implications for a growing low-wage, immigrant, and flexible workforce in the United States.

\section{Neoliberal Theory and Practice}

Nneoliberalism can be described as "a theory of political economic practices that proposes that human well-being can best be advanced by liberating individual entrepreneurial freedoms and skills within an institutional framework characterized by strong private property rights, free markets, and free trade" (Harvey 2005:2). In this sense, neoliberalism views free market exchange as an ethic capable of guiding human action and behavior, holding that social good can be achieved by maximizing the extent and frequency of market participation, and emphasizing the proposition that economic growth is better advanced when the flow of goods, services, and capital is unconstrained by government regulation (MacEwan 1999; Shaikh 2005). However, within the context of modern day political and economic structures and due to neoliberalism's emphasis on freedoms and individual rights, neoliberalism must rely on the State to ensure that an 
appropriate institutional framework is established. This means that in order to create and preserve these practices the state must make use of 'official' structures such as the military, defense, police, and the legal system.

It is important to distinguish neoliberalism as a system of thought from neoliberal restructuring as an actual application of this system of thought. Neoliberalism in its theoretical sense emerged from neoclassical economic formulations that prescribed the market as capable of reshaping individual and collective stability through competition and unfettered markets. Later, supported by a variety of moral neoclassical prescriptions about individual autonomy and decision-making, neoliberalism developed in harmony with Enlightenment ideas that upheld the high political value of liberty (Harvey 2005; Clarke 2005; Fernandez-Kelly 2007). A framework thus evolved around the notion that markets are proficient mechanisms for the creation and distribution of wealth as well as a precondition for the dissemination of democracy and the institutions of political liberty (Fernandez Kelly 2007). To this end, neoliberal restructuring centers on a variety of practical implementations of macroeconomic stabilization, trade liberalization, and the privatization of the economy (Munck 2005).

The distinction between neoliberalism as a system of thought and neoliberal restructuring policies and implementation is important because in search of pragmatism neoliberal policymakers have had to shift from theoretical foundations toward an application characterized by inconsistency and opportunism (Clarke 2005). Such forms of fragmentation have been the focus of much critique and analysis, particularly as its contradictory implications have reshaped a variety of structural processes, from the establishment of economic, legal, and labor regimes to assaults on democracy and civil society (see Sassen 1998; MacEwan 1999; Rapley 2004; Canterbury 2005; Harvey 2005; Saad-Filho and Johnston 2005). More specifically, this fragmentation has been 
able to create contradictory positions that are political and economic in nature but which carry implications for the restructuring of a variety of social structures (Rapley 2004).

First, a problem inherent in the theory and practice of neoliberalism arises from its emphasis on the individuality of rights and freedoms, accountability, and entrepreneurship, which contradict the desire for significant forms of collective life (Harvey 2005). Whether collective or individual, these rights and freedoms are highly regarded tenets of democracy, but under neoliberal implementations create a tension by demanding that political measures are put in place in the interest of economic prosperity (Canterbury 2005). Thus, "while individuals are supposedly free to choose, they are not supposed to choose to construct strong collective institutions" such as trade unions or political parties with a platform of state interventionism (Harvey 2005: 69). To this end, the role of the state should be to support the rule of law, individual property rights, and institutions that promote the free function of markets and trade, and to use its monopolistic control of the means of violence to maintain such freedoms at all cost (Harvey 2005).

The contradiction has become particularly apparent through the struggle led by environmentalists and labor groups around the world as they negotiate through a variety of challenges between the interests they represent and those of corporations and the state (see Greider 1997; Nissen 2002; Tsing 2005; Shelly 2007). Such conflicts are the result of a significant bias in neoliberal practice toward the commoditization of labor and the environment, where the neoliberal State sides with "good" business practices, while opposing the collective rights of labor or the regenerating needs of the environment (Harvey 2005). In this sense, the neoliberal state is hostile to forms of social solidarity that tend to restrict capital accumulation and as a result, trade unions and other social 
movements are disciplined or destroyed in the name of the liberties of individual workers.

A second contradiction emerges from the view that markets work better when free from government regulation, since for neoliberalism the market represents rationality in terms of the most efficient distribution of resources (Munck 2005). But as Polany (2001) points out, the market has been the result of an ongoing intervention on the part of the nation-state, which works to impose market organization in a conscious and often violent way. Under neoliberalism the state becomes a market player itself, helping to reshape and create new market-oriented policies which in turn facilitate the development of a new form of capitalism (Munck 2005). The result is a system in which corporate institutions "secure compromises between management and workers by making appeals to the national interest" (Comaroff and Comaroff 2001: 179). Still, regardless of how powerful the role of corporate and financial interests become, nation-states must continue to adopt policies that promote "fair" market competition, free movement of capital, and curtail the movement of labor across national borders (Robbins 2002).

In the belief that regulation should be controlled and managed through market mechanisms (e.g., tax incentives or impositions, trading rights, trade liberalization, etc.) and not through governmental interventions, neoliberalism can create dangerous conditions for workers as well as the environment by referring containment, planning and regulation to the forces of the market. Within the context of current modes of global capitalist production, such changes bear important implications for individuals and the environment as corporations and individuals rarely pay the full or real costs associated with production and consumption (Robbins 2002). This condition can result in market failure if firms and individuals "avoid paying the full costs attributable to them by shedding their liabilities outside the market." (Harvey 2005) As an example we have 
individuals or corporations that avoid costs by dumping toxic waste or workers that are exposed to dangerous chemicals that may cause physical harm (Harvey 2005:67).

Clearly, at some point someone will have to pay for these costs, whether through higher taxation, health costs, lower wages, or otherwise paid for by future generations (Robbins 2002).

These contradictory scenarios further demonstrate that establishing neoliberalism as a practical form of social organization through deregulation of market structures requires that a variety of policies are put in place. No matter how small the role of government becomes, a neoliberal system will require a structure of implementation and control. In this sense, it has become increasingly clear that with the mobilization and establishment of a global intellectual, political and economic class, neoliberalism has become a real political project throughout nearly the entire world and certainly within the U.S. which strongly attempts to shape the world according to its ideological foundations (Clarke 2005; Munck 2005). In this sense, globalization is seen as the extension of neoliberalism through different levels of regional, international or global integration. As Leisnik (1999) explains, the neoliberal project sees in globalization the advantages of efficient production, financial discipline, cheaper products and services, and a global approach to unemployment and welfare.

But how has the neoliberal project been able to achieve global permanence in the last three decades? As several authors have shown, advocates, prescribers, and followers of neoliberalism have been able to position themselves in positions of power and decision-making throughout a variety of influential financial and political regulatory bodies (Stiglitz 2002; Harvey 2005; MacEwan 2005). In the next section I focus on the formation and maintenance of regulatory regimes as powerful mechanisms in the 
expansion of neoliberal trends across the globe and their influence in the processes of globalization taking hold in the world today.

\section{Regulatory Regimes}

Much discussion about the economic restructuring of the last three decades has centered on the role that multinational corporations have come to play in the world's economy since the late 1970s. In many ways, the multinational corporation has become the best equipped institution to perform the task of global integration by shifting the power of government toward a few financial institutions through the use of private financial resources for public purposes. In this sense, multinational corporations have been able to acquire power to enlist, maneuver, and manipulate government institutions and international agencies toward the creation of policies that facilitate their agendas (Robbins 2002). However, the mission of the corporation is nothing without a system that legitimizes its role as an engine of change; and in this sense, it has been the role of powerful elites to reshape and influence governmental agencies and international regulatory bodies in search for world-wide economic stability (Stiglitz 2002). In this view, it is only after several steps have been taken by powerful political and economic elites that corporations can advance their agendas in developing countries through direct investment.

One way through which political and economic elites have succeeded in consolidating a position of power and accumulation is through the establishment of influential networks and more specifically through the implementation of regulatory regimes (Rapley 2004). It can be argued that in modern capitalist society, both, political

and economic elites are related in mutual bonds of dependency, which allow them a high degree of political leverage and the ability to exclude the masses from the political process. The notion regulatory regime formation is largely present throughout the 
literature on neoliberalism and globalization, although different authors have conceptualized the issue as one of power restoration to the economic and political class through imperialism or authoritarianism (see Canterbury 2005; Radice 2005; Tabb 2001; Rapley 2004). However, and independent of conceptualizations being used, consensus in the literature is strong that the implementation of neoliberal reforms of the last 30 years has served the best interests of the global power elites (see Canterbury 2005; Radice 2005; Tabb 2001; Rapley 2004. Light (2007), explains this phenomena as a latent function of the globalization process, in which actions aimed at to serve world interests, largely serve the interests of powerful political and economic groups.

The establishment of regimes by political and economic elites has also had an impact on traditional modes of commodity production in the developed world. Berger and Piore (1980) foresaw some of these issues as embedded in the relationship between market expansion and the survival of traditional industries, ${ }^{2}$ where the survival and permanence of the traditional sector and its role can also be understood as resulting from inherent features and tensions among actors in advanced industrial societies. Just as in the neoliberal context of globalization, the resilience, adaptation, and reproduction of traditional industries and business groups are centrally related to economic incentives and market conditions that are politically arranged, and which can be observed in the state's willingness to overlook labor violations of social security, minimum wage, and working conditions. As in the case of global economic development, these relationships are forged by values, norms and expectations which groups in society hold and which

\footnotetext{
${ }^{2}$ Berger and Piore (1980:91) define traditional industries as those that produce the same goods and services as other, modern firms in the market, but which are characterized by smaller firm size, higher labor capital ratios, lower productivity, and other characteristics associated with small, independent property owners, farmers, shopkeepers, artisans, and certain small and medium businessmen.
} 
result in political decisions to protect the role and function of the traditional firm (Berger and Piore 1980).

Whether in the form of authoritarian or democratic governing, the relationship between economic and political elites must work within the structure of the state. In this sense, the neoliberal state can be described as a governing apparatus for which the freedoms embodied in it reflect the interests of private property owners, businesses, multinational corporations, and financial capital (Harvey 2005). It could be argued that the state in turn responds to claims from capital by producing new forms of legality that advance the interests of certain economic actors while weakening those of others (Sassen 1998). In this sense, it becomes clear that globalization "is about relations of relative power, dependence as much as exchange, and how otherness becomes naturalized or provokes resistance. Far from being a merely technical matter, globalization is a deeply political process (Tabb 2001; 13)." Through this lens, we can see how globalization is mediated by a series of governance networks that operate at both transnational and local levels, and which require a variety of social mechanisms to enforce contracts and standards of judging what is considered permissible behavior by participants.

In economic terms, the formation of such regimes has resulted in a polarization of the wages and salaries of workers as well as of the use of land, and the organization of labor and housing markets (Sassen 1998). For the labor market, this shift has signified a strict regularization of unionization rights and of the suppression of strikes, as these are viewed in opposition to the objectives of the power elite (Harvey 2005). Similarly, in its domestic applications, neoliberal restructuring has truncated the rights of access to food, water, education, work, land, medical care, and a variety of other public amenities (Saad-Filho and Johnston 2005). Under the current phase of political and economic 
developments, the opportunities for labor and capital to meet in the market-place have changed dramatically (Shelley 2007). Technology has facilitated this process by allowing deals to be discussed and formalized across the world over cell phones and money to be transferred at the push of a button. However, for millions of potential and low-wage workers, the conditions at the marketplace are not the same as for those with the ability to influence finance, trade and production. For the workers, the decisions and processes of incorporation into a regional or even global economy are more complex and dramatic (Dusster 2006).

It is precisely in the area of labor where the push to deregulate the functions of regulatory agencies that (under the premise that market forces better solve the problems of income distribution) neoliberal restructuring has remained loyal to its theoretical foundations. Since the early 1980s, labor market deregulation has resulted in the decreased value of the minimum wage, increased employment insecurity, a widening of the wage gap, and significant losses in employment protection (Saad-Filho and Johnston 2005, Glyn 2006). Marx saw this as an inevitable product of capitalism, where accumulation for a minority grows exponentially with its ability to exploit labor out of a weakened and powerless labor force (Marx [1867] 1978). In the context of neoliberalism, higher value is given to flexibility in production or manufacturing, resulting in increased job insecurity, lower wages, and a loss of benefits for the working class (Harvey 2005) Many of these practices can be traced back to the late 1960s, when a crisis of profitability resulted from an excess of productive capacity in relation to effective demand (Greider 1997). Many U.S. transnational corporations responded by relocating production sites to less unionized areas of the country - usually in the south - or to less developed countries in an attempt to lower wage costs and to restore profitability (Greider 1997, Stiglitz 2002). By opening factories in developing nations, transnational 
corporations were able to save on production costs while justifying free trade as an equalizing force that would bring positive economic changes to the countries where they settled (Fernández-Kelly and Massey 2007). Again, in its regional and global implications, neoliberal regimes proved to establish a new discipline of labor and management that largely benefits lenders and shareholders while providing a diminished role of the state in the development of welfare and development (Saad-Filho and Johnston 2005). For the US labor market, the shift toward a global expansion of neoliberal economics also signified a variety of other trends that have largely intensified since the 1980s.

Take for instance the noticeable increase in low-wage jobs in the United States in recent decades. In many ways, this change has been the result of the same global forces that have channeled investment and manufacturing jobs to developing countries, whereas the United States' industrial production has moved overseas, the traditional manufacturing base has downgraded into a second-rate manufacturing sector characterized by a large supply of low paid, semiskilled, and unskilled production jobs (Sassen 1998). In developed nations, these circumstances degrade the conditions of work in a similar legal climate of poor nations, as industry has revived many old forms of exploitation and abuse outlawed long ago in the advanced economies, "including dangers to workers and the use of children as expendable cheap labor" (Greider 1997:34).

More examples can be observed as sweatshops have re-emerged from New York to Los Angeles, and as manufacturing sectors feel the pressure to remain competitive in the global-economic landscape labor standards and wages embark in a race to the bottom, where gains in capital have increasingly become losses for labor (Greider 1997). In addition, many U.S. companies have downsized or simply closed as they have 
become victims to the laissez-faire rules of free market policy, causing massive layoffs and disrupting the lives of individuals and families along with the consumption and saving patterns at the macroeconomic level (Otero 1996).

In essence, the aforementioned problems of neoliberalism and economic globalization have intensified by corporate actors, who backed by political and economic elites, have pursued a defensive strategy based on lowering wage costs. This strategy, "has proved to be incompatible with increasing standards of living for large sectors of the population" and in the case of Mexico resulted in a less equitable society, with a large number of people under the poverty line and declining real wages for unskilled work (Otero 1996:5). In the U.S. some of these consequences have been particularly harsh in those industries that cannot be transferred to other regions of the world since they are not able to compete against globally movable industries, and end up depending on some of the lowest wage workers available in the labor market. Jobs in industries such as hospitality, construction or farming of perishable goods in the developed world have become increasingly dependent on a mobile workforce in order to perform jobs in those specific locations where work is place bound. Under the current phase of neoliberal restructuring, this condition often puts many industries at a disadvantage in relation to those firms that can exploit labor by finding it cheaper abroad (Shelly 2007).

However, many of the claims made by the critics of neoliberal globalization need to be reconsidered in the light of economic indicators of recent decades that postulate that the number of people in poverty have decreased significantly, particularly in Asia and Latin America and that wages paid by American multinational corporations abroad pay a premium wage that is higher than the going national rates of those countries where production is taking place (Bhagwati 2007). In structural terms, the world has also witnessed a significant economic growth in those countries that have welcomed 
international investment in manufacturing and services, such as China and India, which, would also indicate a positive outcome to some of the policies adopted through the breaking down of barriers to trade and finance (Bhagwati 2007, Stiglitz 2002). It is hard, however, to ignore many of the questions that positive changes in specific geopolitical areas bring about, such as the growth of poverty in the African continent or the economic demise of Russia after the fall of the socialist block (Bhagwati 2007, Stiglitz 2002). In the end, what these different scenarios seem to point out is the degree to which neoliberal globalization has provided a fragmented and uneven setting for growth and development with increase in inequality in a variety of areas such as concern for the environment, the rights of labor, democracy, and human rights (Stiglitz 2002, Trouillot 2003).

In the following section, I look at the establishment of the North American Free Trade Agreement (NAFTA) as a practical implementation of neoliberal policies, focusing on the way in which the decisions of powerful actors had a wide effect on a variety of socioeconomic social structures, institutions, and the individuals who despite being excluded from the decision making process, suffered its harsh effects.

\section{NAFTA - Free Trade Policy in Practice}

Taken together the contradictions in the theoretical and practical applications of neoliberalism and highlighted in the previous section can be seen in the implementation of the North American Free Trade Agreement (NAFTA). As Fernández-Kelly and Massey (2007) explain:

The interests of capital are reflected in the considerable emphasis NAFTA puts on intellectual property rights, patents and copyrights, and the rights and privileges of ownership compared with its curious silence on issues related to labor and the environment. From the American point of view, the twin purposes of NAFTA were thus to provide manufacturers free access to Mexican workers, thereby enabling a new international division of labor, while at the same time giving investors unhindered access to Mexican property and financial assets. 
The negotiations that lead to the establishment of NAFTA did not include trade unions, public interest organizations, or small business associations, implying a deliberate attempt to benefit particular corporate interests, while disregarding the interest of excluded groups (Gelinas 2003; Fernández-Kelly and Massey 2007). It is possible that inclusion of trade unions and other public interest organizations would have allowed a more democratic and egalitarian system that could benefit workers and the environment through a more inclusive development process. Instead, NAFTA created an array of negative and dangerous conditions for workers and the environment in Mexico and the United States (Massey, Durand, and Malone 2002; Gelinas 2003; Otero 19996).

The North American Free Trade Agreement was established in January of 1994, seeking to open Mexico and Canada's service markets, ease restrictions in the area's auto industry, open access in Mexico to U.S. agricultural products, provide fair rules for investment, and increase access of Mexico's state owned energy companies to U.S. firms (Kingsolver 2001). However, as Randall (1992) explains, the motivations for the involved nations were quite different. For the U.S., motivations can be understood in two specific ways. First, political aspirations projected to establish Mexico as a model-tofollow for other politically and economically unstable nations of Latin America through the establishment of similar trade agreements in the area (Randall 1992). Second, the agreement was an investor's charter of rights and freedoms that gave U.S. multinational corporations priority over environmental, social, and economic policies in Mexico and Canada (Gelinas 2003). These views acquire stronger validity in light of the impacts that NAFTA has had on the U.S. In terms of job impact, several studies contend that NAFTA has been responsible for thousands of lost jobs in the U.S. - although these have been offset by the creation of greater number of jobs during the economic boom of the 1990s and there is no evidence that NAFTA has had a discernible effect on the U.S. aggregate 
trade balance (see Mary E. Burfisher, Sherman Robinson and Karen Thierfelder 200, for a complete analysis).

For Mexico, the treaty called for an upgrade to the country's industrial and technological base, the creation of jobs, the expansion of international markets for Mexican products, and provided an effective way to foster domestic reform while achieving continuous economic growth (Randall 1992). However, in Mexico "import liberalization, the overvalued exchange rate, high absolute and real interest rates, and domestic divestment have generated disincentives for manufacturing" (Otero 1996:80). In the end, NAFTA resulted in an increase of import-oriented industrialization with limited links to the local economy and with limited impact on the creation of manufacturing jobs in Mexico. In addition, manufacturing became dominated by U.S. transnational corporations and a few domestic monopolies which were quickly able to adapt to changes in face of restructuring (Otero 1996). Thus, those firms that could not adapt struggled or perished, producing a high degree of industrial mortality in the early years of NAFTA (Heath 1998). Manufacturing growth was roughly .06 percent between 2000 and 2006, with employment falling 15 percent, and indicating the degree to which industrial development in Mexico has served U.S. interests by increased productivity and wage suppression while substantially reducing the profitability of Mexican-owned industries (Delgado Wise and Cypher 2007).

On the agricultural side, the NAFTA policy that accompanied economic restructuring focused on bringing subsistence farmers out of "unproductive" farming and aimed at privatizing $50 \%$ of Mexico's land base ${ }^{3}$ to invest in export production of fruit, produce,

\footnotetext{
${ }^{3}$ As a result of the Mexican Revolution of 1910, the Mexican Constitution of 1917 created the Ejido as a land tenure system which granted land to the "landless" and the "displaced" through agrarian reform and land redistribution which largely benefited the indigenous and peasant populations of the country by creating communal lands for cultivation (Vazquez Castillo 2004).
} 
and other crops (Stephen 2007). As Stephen (2007:125) explains, NAFTA produced unintended consequences for farmers in the lower ranks of the economic ladder by allowing

Ever-increasing amounts of U.S. corn - primarily yellow corn for animal feed - and other products to enter Mexico to compete with those produced by subsistence farmers... Rather than knocking out all corn farmers in Mexico, U.S. imports of yellow feed corn in combination with the end of guaranteed prices... resulted in an increase in corn production among middle size and larger farmers with access to irrigated land. This phenomenon drove out subsistence farmers that could no longer compete with the middle and large growers who had access to better technology in irrigation as well as the financial power to deal with the growing costs of production. This trend had unintended consequences for peasants, as they became proletarianized and sought to find employment in a variety of industrial sectors or sought economic advances in the U.S. labor market.

Proponents of NAFTA expected to control Mexican migration to the U.S. under the logic that job creation and increased economic development in Mexico would deter migration flows to the U.S. (Kingsolver 2001). This strategy is consistent with the view that "the U.S. Government has attempted to promote economic growth in the migrantsending countries by encouraging direct foreign investment and export-oriented international development assistance, in the belief that rising economic opportunities in the developing world will deter emigration" (Sassen 1998:32). However, as Sassen (1998) explains, there is a separation of migration and labor migration within the conceptualization of NAFTA in which there exist some considerations regarding the regulation of service workers in finance and investment ${ }^{4}$ - presumably skilled and more likely to become 'mainstream Americans,' but no considerations for low-wage, poor and

\footnotetext{
${ }^{4}$ The 1990 Immigration Act increased the limitations to the family reunification clause of the U.S. immigration policy while the1993 passing of NAFTA increased some of the technical categories through which people from Mexico and Canada could migrate to the U.S. Specifically, these new qualifications gave rise to an increase of business visas, student visas, and intracompany transferred personnel from Mexico, while a strong militarization of the Southern U.S. Border through operations "Blockade" and "gatekeeper" fervently sought to keep low wage immigrants from entering the country Fernandez-Kelly and Massey (2007).
} 
uneducated labor migrants. As a result, migration is left to be enforced and regulated by state agencies that view migration not as a function of structural conditions, but instead as the outcome of individuals seeking better opportunities for themselves (Sassen 1998).

Several scholars point out that rather than controlling immigration NAFTA actually increased it (see Sassen 1998; Stephen 2007; Castro 1990). The number of migrants from Mexican villages and rural communities who relocated within the country and to the United States increased 352 percent between 1980 and 2002, while in the United States this meant a $452 \%$ increase of rural migrants from Mexico between those same years (Stephen 2007). The flow has been influenced by the implementation of policies aimed at de-regulating the flow of capital, goods, services, and information while ironically, regulating the flow of labor and delegating its control to state agencies that are separated from the economic emphasis behind treaties like NAFTA (Sassen 1998).

\section{Trade Regulation in a Sea of Free Trade}

The movement of people across international borders is not the only controversial issue that follows the establishment of global and regional neoliberal policies. NAFTA opened up a variety of markets for U.S. based companies and products to enter Mexico and Canada; however, there still remain a variety of policies designed to protect plant health and consumer health in developed countries that curtail the trade of goods between international actors in the opposite direction. Sanitary and phytosanitary (SPS) measures, for instance, have been established to protect living beings, that is humans, animals, and plants, from the dissemination of pests or disease (Burnquist, Barrs, Miranda, and Filho 2004). Theoretically, within the context of trade liberalization and global integration, these measures have been sought to facilitate production and exchange, reduce transaction costs, and improve quality; however, at the practical level, 
a variety of conflicts arise between domestic regulations and international trade systems as regulations often work to restrain international competition (Burnquist et al. 2004).

In the broad international context, an international SPS agreement is governed by the WTO and specifically seeks to "protect and improve the current human health, animal health, and phytosanitary situation of all Member countries" and "Protect Members from arbitrary or unjustifiable discrimination because of different sanitary and phytosanitary standards" (Henson and Loader 2000). One of the main issues associated with SPS restrictions is that individual nations can take legitimate measures to protect the health of living organisms given the risk level that they deem "appropriate" as long as such measures do not unnecessarily restrict trade (Henson and Loader 2000). The Agreement, thus, distinguishes between protection and protectionism, which is defined as trade regulations that go beyond the desired level of protection. These measures are not supposed to discriminate against trading partners of identical or similar quality conditions and cannot be maintained without sufficient scientific evidence that ensures their adequate level of protection (Burnquis et al. 2004).

To this end, the SPS Agreement recognizes that

Pest or disease free-areas are largely determined by geographic and other ecological conditions, and not by political boundaries, such that they may be part of one country, several countries, or all countries. Import protocols must therefore be based on a risk assessment that evaluates claims by exporting countries that certain regions are free of quarantine diseases or pests, or that prevalence of quarantine pests and diseases is low (Burnquist et al 2004: 168).

Still, the U.S. strongly restricts the importation of plants and plant products through the Plant Protection and Quarantine (PPQ) program. But as the liberalization of tariffs and other trade regulations in agricultural and food products has continued to expand, much criticism has been directed at the proliferating use of "technical" measures for food safety regulations, labeling requirements, and compositional standards by the U.S. and 
other developed nations. For many developing nations, this growing trend reflects a wide-held recognition that technical measures can, and are being used as barriers to free trade by developed countries (Henson and Loader 2000).

Examples of the interaction between SPS regulations and international trade abound in a variety of economic and agricultural journals; however, the relationship between SPS regulation and the social interactions which facilitate them in developed countries has not been explored. Neither has their relationship to patterns of international migration nor their consequences within the larger global and regional neoliberal restructuring trends of the last three decades. I hypothesize that the answers to these questions are deeply embedded within the relationship between economic elites, traditional industries, corporate power, and policy-making highlighted in this chapter, and will address them in the results section of this manuscript.

\section{Neoliberal Restructuring and the Reorganization of Labor in the U.S.}

In this section, I discuss how work has been reorganized to reduce the power of labor to demand better wages and benefits. Capital, with the collaboration of the state have downsized, threatened to close or move shops either to lower wage regions of the U.S. or abroad, and demanded more flexibility from workers through part-time and temporary jobs that generally pay lower wages with fewer or no benefits. These moves have been supported by the withdrawal of the state from the regulation of workers and worker conditions, including specific regulations from the state that undermine the ability of workers to organize.

Several authors have argued about the degree to which economic restructuring changes of the last 30 years have been able to transform the labor market through the use of a variety of strategies (see Blau 1999: Grenier 1988; Lamphere, Stepick, and Grenier 1994; Sassen 1998; Bonacich and Applebaum 2000). As these authors 
demonstrate, such measures occurred largely within a context of industrial (re)organization, and corresponded to specific changes implemented by capital in the early phase of neoliberal restructuring. These measures have entailed the use of distinct strategies such as the use of low-wage, low-skill labor, through which companies are able to maintain low production costs and resist rising wages; the movement of centers of production to areas of the country where wages are lower, particularly in rural areas of the south, or by threatening to close shop and move to Mexico or other developing countries, and; by downsizing and the flexibilization of the workforce.

Flexibility has become the new industrial model for operations, reflecting changes of economic restructuring in a post-Fordist production system where mass production has moved beyond the assembly line into smaller batches of market-specific production (Bonacich and Applebaum 2000). According to Green (2003; 39) flexibility can be described as the avoidance of fixed costs, a fixed labor force, and fixed rules, which permit "the adjustment of supply to demand by cutting the risk of long term investment, adjusting the labor force to production needs, and limiting rigidities due to union and legal restrictions that regulate wages, benefits, social welfare payments, and working conditions." Flexibility can take many forms, including: (1) increase in homework operations; (2) work given to subcontractors who in turn hire their own workers under, often, irregular and unregulated conditions; (3) a variety of temporary, short-term and part time jobs; and (4) a decreasing opportunity for unionization (Bonacich and Applebaum 2000).

Previous to this phase of restructuring, an 'accommodation' had been reached between organized labor and industry as a result of labor-favorable legislation of the New Deal, The policies of the New Deal gave workers protection and ability to organize and bargain collectively while creating an environment where "in exchange for union- 
demanded wages and benefits, workers would cede control over industrial production to management" (Bonacich and Applebaum 2000: 6). The cost of this arrangement was transferred to the market-place in terms of higher prices for goods and services, but it was accepted under the premise that higher wages and benefits would provide workers with expendable income to promote the cycle of consumption and production that would, in turn, generate jobs and prosperity (Bonacich and Applebaum 2000). The trade-off lasted until the 1970s, when capital began to blame high costs of labor as the reason for limited competitiveness and as resulting from the intervention of trade unions (Bonacich and Applebaum 2000). The trade-off thus began to erode as new plants opted to remain nonunion while capital selectively applied patterns of plant relocations, closings, and other alternatives that prepared the field for massive assaults on organized labor in the 1980s (Nissen 1990).

To combat the phenomenon of "market distortions," capital introduced a variety of policies aimed to control and reduce workers wages and benefits beginning in the 1970 s (Campbell 2005). Such changes were accomplished through six concrete activities that determined the new shape of the capital-labor relations under neoliberal restructuring and included: (1) increased foreign production, increased domestic unemployment, and downward pressures on wages and benefits; (2) the introduction of wage freezes and wage cuts; (3) the elimination of Cost of Living Adjustment (COLA) clauses from workers' contracts; (4) the emergence of two-tiered wage structures that gave new workers significant lower salaries for the same work in comparison to established workers; (5) the replacement a full-time workers by part-time or temp workers in order to generate savings on health, pensions and other benefits, and; (6) union avoidance and union busting sanctioned by the government (Campbell 2005). In addition, by giving managers strong incentives in the form of stock options, institutional shareholders gave 
managers strong incentives to do whatever they could to boost company profits. The implementation of managerial incentives, again, often meant the destruction of jobs, plant closings and a loss of wages and pension levels as prime means of achieving shareholder value (Glyn 2006).

In addition, while promoting the relocation of plants and offices abroad, a large demand grew to fulfill a number of low wage jobs that could not be transferred overseas, creating an expanded supply of low wage jobs in the U.S. (Sassen 1998). To this end, Glyn (2006) shows the way in which low-wage labor has been negatively impacted by the displacement of low skilled manufacturing from imports, advancements in technology which have displaced workers in tasks which can be routinized, and the "bumping down" of workers to jobs that had been previously reserved for the least qualified. Faced by technical progress and structural change, the less skilled were forced to accept lower relative pay in order to remain employed, with unemployment as the only alternative (Glyn 2006P). For the advocates of labor market deregulation, reducing benefits, cutting employment protection, and allowing the minimum wage to decrease signify a trade-off which would ultimately result in job creation, but the evidence of cross national studies demonstrates that change in job creation has not been significant in countries where such measures have been set in place (Glyn 2006).

After a significant hiatus in American industry, sweatshops 5 re-emerged in a variety of U.S. cities since the 1970s and 1980s (Rosen 2002; Bonacich and Applebaum 2000).

\footnotetext{
${ }^{5}$ The sweatshop concept has traditionally been used to analyze production of garments and the dreadful working conditions embedded in that type of production. As Bonacich and Applebaum (2000: 3) explain, "a sweatshop is usually defined as a factory or a homework operation that engages in multiple violations of the law, typically the nonpayment of minimum or overtime wages and various violations of health and safety regulations." Other authors expand the definition to include factories that fail to pay a "living wage" to their employees. Ness (2005) uses the term to describe the working conditions and environments of workers in New York City's greengroceries, further adapting the applicability of the term to fit other industries. Similarly, Bender and Greenwald (2003) point out the validity of the term to encompass, industries in manufacturing
} 
Previously, pro-labor legislation had secured workers the right to organize and provided them an environment of relative agreement between capital and labor that lasted until a variety of economic changes began to take hold in the 1960s and 1970s (Nissen 1990; Applebaum and Bonacich 2000; Harvey 2005; Glyn 2006). One example, elucidated by as Lamphere, Stepick, and Grenier (1994) showed how changing structural demands for flexibilization created new sources of conflict while deteriorating working conditions for garment workers in South Florida garment plants. Again, the search for flexibility on an already flexibility-demanding industry and changes at the macroeconomic level brought real changes to garment the industry in the U.S. Such changes have been similar in other service and manufacturing industries as these are pressed to reduce labor costs through the minimization of job stability, subcontracting, benefit reduction, and union condemnation (Bonacich and Applebaum 2000).

Production of garment manufacturing is in many ways similar to other industries in the U.S. Specifically, industries that depend on seasonality tend to be risky and highly competitive based on a variety of factors which may include: (1) low-tech, labor and intensive production, with low capital requirements; (2) the unpredictability of cycles that leads employers to externalize risks by contracting out labor and enhance flexibility; (3) a presence of powerful retailers that intensifies competition among producers; and, (4) low capital requirements that create an environment of immigrant entrepreneurs who in turn create low wage jobs for co-ethnics and other labor immigrants (Bonacich and Applebaum 2000). The issue of contracting has been the center of a great deal of attention, as it has been used by employers to curtail the influence of organized labor while passing some of the operational risks on to the contractors (Bender and

with violations of federal or state labor laws, including wage and overtime, child labor, industrial homework, occupational health and safety, or any other industry violation. 
Greenwald 2003). Some of the major issues in contracting work emerge from a pressure on bidding (or underbidding) which leads to downward costs that exacerbate already poor working conditions (Bender and Greenwald 2003). For ethnic entrepreneurs and middlemen, the issue becomes problematic as they themselves become victims of the more powerful players in the 'sweatshop relation,' and as Shelby (2007) argues the line between the exploited and the exploiters begins to blur.

As I mentioned earlier, the decrease in working conditions at the industrial setting came accompanied with decreasing levels of unionization. As Piazza (2002: 13) explains, for neoclassical economists "unions and collective bargaining represent significant distortions of the labor market which, in turn, have deleterious effects on the economy as a whole," since with unions, social wage-setting is done on a political basis rather than on efficient market-oriented decision making. This tenet of neoclassical economics continues to be a strong factor in the neoliberal agenda, affecting the process by which unions and workers bargain collectively in the labor market. Piazza (2002), on the other hand argues that when individual workers negotiate wages or working conditions alone, they suffer from a lack of power vis-à-vis their employers that restrains them from enjoying higher levels of remuneration and better working conditions than if they organize or bargain collectively. Unfortunately, by 2004 union density in the U.S. had fallen precipitously to about 9 percent in the private sector - about a third of the level that prevailed in the 1970s (Milkman and Voss 2004).

With the onset of neoliberal restructuring the U.S. government actively supported various attacks on labor (see Nissen 1990; Campbell 2005). Amidst the depression of 1981-1982 monetary policies where put into place by the administration, undermining the bargaining power of organized labor (Seybold 1990; Campbell 2005). As shown by Campbell (2005), the government allowed the minimum wage to drop in real value; 
reinterpreted labor laws in ways that were convenient to the interests of the power elite including appointment of anti-labor figures to the National Labor Relations Board (NLRB) and a series of rulings that strongly reduced workers ability to organize unions, strike, or bargain collectively with their employers. In this sense, the government directly engaged or supported union busting techniques along with the establishment of the two-tiered wage system; and, weakened the welfare safety net by reducing unemployment benefits, trade adjustment assistance, public-service employment jobs, and aid to families with dependent children.

The attack on labor unions was exemplified by Reagan's busting of the Air Traffic Controllers strike that sent a powerful message to corporate interests about the nature of the administration's stance on organized labor (Seybold 1990). Adding to the issue were very sophisticated strategies by multinational corporations in an era where the pervasiveness of neoliberal ideology undermined the legitimacy of any collective action that affects the labor market (Milkman and Voss 2004). In this sense, Bronfenbrenner and Hickey (2004: 38) found that a significant number of employers "aggressively opposed the Union's organizing efforts through a combination of threats, discharges, promises of improvements, unscheduled unilateral changes in wages and benefits, bribes and surveillance," as well as a variety of threats of plant closure during organizing drives.

Despite the setbacks, some authors point to the degree to which rising trends in neoliberal restructuring have created new conditions for the improvement and growth of organized Labor (See Nissen 1990; Nissen 2002; Bronfenbrenner and Hickey 2004). As Seybold (1990: 81) states regarding the policies established by the Reagan administration, they "have also unwittingly provided the social basis for a resurgent labor movement" since "the creation of a more polarized, two-tier society provides the social 
and material base for a broad coalition movement for social justice, in which the labor movement could play a crucial part." Today, workers in a variety of industries are finding more sophisticated employer opposition to organizing, coupled with restructuring at the corporate level, foreign trade investment, and shifts in work and production (Bronfenbrenner and Hickey 2004). Still, although the legal, political, and economic environment continues to negatively affect worker organizing in the U.S., some battles are being won through a variety of strategies and methods for organizing (Bronfenbrenner and Hickey 2004).

The majority of organizing efforts concentrate in relatively small for-profit companies; however, a growing number of strategies have sought to include non-profit industries such as hospitals, social service agencies, and educational institutions. The shift has also sought to include private and immovable workplaces that cannot be outsourced, such as restaurant work, hotels, and nursing homes (Bronfenbrenner and Hickey 2004). In addition, as Milkman and Voss (2004) explain, a new campaign to organize the "unorganized" has been set in motion by the AFL-CIO since the mid 1990s, where more resources and new strategies have been placed in motion to reach out to workers in particular industries where organized labor has weakened or did not exist before. New organizing efforts have produced positive gains, but they have been modest since they have concentrated in a few occupations and industries and their success has been hard to replicate across a wide spectrum of industries in the country (Milkman and Voss 2004).

\section{Conclusions}

One important aspect of the neoliberal reform of the last 30 years is that its political, social, and economic ramifications extend through a variety of local, regional, and global levels. In this sense, with the benefits afforded by technology, capital has been able to 
relocate to far regions in search of cheaper costs of production, while expanding consumption to foreign markets in search of profitability. At the same time, the manufacturing base in the U.S. has been reduced or degraded, as low-cost service industries replace the jobs of the eroded manufacturing industrial base. These trends have come at the hand of powerful elites and political figures for which neoliberalism has become a concrete political project that has not only exported jobs and reduced wages but also has contributed to the demise of trade unions and other forms of collective action that would protect workers from the adversities of the market. As I have shown in the previous sections, the demise of these collective organizations has come from growing direct foreign investment, as well as from deliberate attacks by government and corporate actors.

By and large, these changes have been facilitated by technology as much as by a deregulatory system which continues to relegate the responsibilities of state actors to capital interests under the premise that the social good can be best achieved through the maximization of unregulated market participation. In this sense, the state itself has become suspect of inadequately distributing and managing resources and a move toward market oriented policies began to take shape across a variety traditionally statemanaged ventures. Such a deregulatory process entails the creation of other regulations and regulatory regimes that ensure that the interests of powerful market actors are preserved. Again, these changes have had serious implications for labor, as regulation falls in the hands of actors who represent those interests of capital and overlook the interests of individual workers.

The implications for workers in South Florida plant nurseries do not lie beyond the domain of the neoliberal reforms of the last three decades. But inevitable questions do emerge in the context of this industry's traditional use of low-wage immigrant workers 
and the working conditions they have endured for a prolonged period of time. Specifically, how can neoliberal restructuring be conducive to the deterioration of worker conditions in an industry where conditions have probably been quite adverse even before neoliberal changes began to take hold and where international competition does not pose a direct threat to the erosion of the industry? This may be difficult questions to answer, at least within the context of unionization, for agricultural workers have traditionally fallen outside the protections offered by the benefits of collective bargaining. Furthermore, the exploitation of workers may often be the result of the vulnerability they possess because of their lack of migratory status, the lack of English skills, or their marginality from legal resources that could help them advance their interests.

The answer to these questions however may lie within broader structural changes that resulted from the promotion and relocation of plants and offices abroad and which expanded a large demand to fulfill a number of low wage jobs that could not be transferred overseas (Sassen 1998). To this end, Glyn (2006) shows the way in which low-wage labor has been negatively impacted by the displacement of low skilled manufacturing from imports, advancements in technology which have displaced workers in tasks which can be routinized, and the "bumping down" of workers to jobs that had been previously reserved for the least qualified. In the context of the plant nursery industry, those structural changes may also be responsible for the attraction of a large immigrant workforce willing to perform jobs that are labor intensive and offer very low status to native workers.

There are, however, other areas where neoliberal restructuring may play an important role in the socioeconomic outcomes of plant nursery workers in South Florida. In terms of business practices and within the growing nature of sweat shop conditions across a variety of U.S. industries, the area's plant nursery industry is prone to respond 
to similar patterns seen by Bonacich and Applebaum's (2000) study of apparel manufacturing. Specifically as plant production depends greatly on seasonality, business tends to be risky and highly competitive considering a variety of factors such as lowtech, labor and intensive production; a presence of powerful retailers that intensifies competition among producers; and low capital requirements that create an environment of immigrant entrepreneurs who in turn create low wage jobs for co-ethnics and other labor immigrants. These trends, along the unpredictability of cycles lead employers to externalize risks by contracting out labor in search for increased flexibility, while passing some of the operational risks on to the workers.

At the policy level, the state of Florida lacks a department of labor and must rely on district offices of the federal Department of Labor to enforce labor law. The state's department of labor was transformed [insert date] into the Agency for Workforce Innovation which according to the agency's website is partnered with and guided by "Workforce Florida, Inc" in the running of 90 career centers in the state as well as in a variety of research, statistics, and program development. At the federal level, the number of Wage and Hour investigators declined by 14\% between 1974 and 2004 with compliance actions declining by $36 \%$, while the size of the workforce and business establishments grew $55 \%$ and $112 \%$ percent respectively (nelp.org). These trends in labor enforcement and deregulation have occurred within the current period of Neoliberal restructuring and provide ample room for exploration within the context of wage theft and other forms of worker exploitation across a variety of industries in the state. For plant nursery operators, an environment of decreased regulation and enforcement and an already existing antiunion environment may provide the right conditions to exploit workers through wage theft and worker misclassification. 
As I have argued on this chapter, neoliberal implementations of the last three decades have had a dramatic impact on a variety of socio-economic structures of the world. Specifically, neoliberal policies have helped to shift the power of governments toward a few financial institutions and a variety of multinational corporations. In many ways, such transformations have occurred as powerful elites have acquired power to enlist, maneuver, and manipulate government institutions and international agencies toward the creation of policies that facilitate their agendas through a system that legitimizes their role as engines of change. In economic terms, the formation of such regimes has resulted in a polarization of the wages and salaries of workers as well as of the use of land, and the organization of labor. For the latter, this shift has signified a strict regularization of unionization rights and of the suppression of strikes, as these are viewed in opposition to the objectives of the power elite, while also truncating the rights of access to education, work, land, medical care, and a variety of other public amenities. In the next chapter I turn my attention to labor migration and the role that such structural changes may play on the lives of millions of workers of the developing world as they toil in fields and factories of the U.S. under current modes of neoliberal policies and capitalist production. 


\section{LABOR MIGRATION TO THE U.S.}

More than ever before, a variety of industries in the United States depend on the labor, and more specifically, on the cheap labor of immigrants to remain competitive within the context of globalizing economic markets. As I discussed in the previous chapter, such economic changes have had a significant impact on the restructuring of a variety of political, social, and cultural arenas through the implementation of neoliberal economic restructuring of the last three decades (see Sassen 1988, Sassen 1998; Massey, Durand, and Malone 1992; Goldin 1999). The changes have also had a dramatic impact on the lives of millions of workers who toil in factories, restaurants, and farmlands of the developed world. These individuals are increasingly immigrants from "less developed" areas of the globe who find themselves in a process of incorporation into capitalist structures (Griffith 1993). These economic developments also have the ability to place workers in marginal and vulnerable spaces of the market economy, as they struggle to adapt to changes in the political economy of a globalizing world.

On this chapter I on the conditions and challenges associated with the mobility and incorporation of immigrant workers to U.S. labor markets. I argue that visible forms of exclusion, exploitation and marginalization are embedded in a complex interaction of structural processes where economic incorporation, immigration policy and discourse, and the politics of labor organizing, help to create an environment of vulnerability that is propitious for the marginalization and exploitation of the immigrant labor force. To this end, I discuss the literature on economic incorporation of immigrants into receiving economies of the developed world, literature on U.S. immigration policy with an emphasis on its relevance to low-wage immigrants in the workforce, and the ways in which traditional unionization models have excluded the immigrant labor force. A substantial emphasis of this argument, however, will center on emerging literature on 
exploitation and marginalization by employers of immigrant workers and the efforts to protect workers through unions and grassroots organizations.

I will deal specifically with labor migration as a useful classification to represent those immigrants who only possess their labor power as a source of income. Labor migrants represent the bulk of migration - both legal and undocumented - to the United States and should be distinguished from skilled and entrepreneurial migrants who possess capital for investment or have achieved high educational credentials (Portes and Rumbaut 2006). Labor migrants have come to represent the stereotypical notions of contemporary immigrants in the United States; they gravitate toward jobs that the native workforce refuses to accept, often see themselves as temporary workers planning to return home, tend to be unskilled, are often unschooled, and often come from rural areas in their sending countries (Piore 1979, Portes and Rumbaut 2006). The majority of labor immigrants to the United States cross the border on foot or overstay their tourist visas; however, many find themselves coming into the country legally through some of the family reunification preferences procured under the 1965 Immigration Act or through the use of contract labor (Portes and Rumbaut 2006).

\section{U.S. Labor Migration and Immigrant Incorporation}

Notions about the process of migration have been explained through different theoretical approaches, yet traditional theory and research have centered on the questions of why migration occurs, how it is sustained over time, and what are the social and economic consequences of the presence of immigrants in host societies (Shmitter Heisler 2000). Neoclassical theories view migration as a way to relieve sending countries from population pressures, overcome rural unemployment, or to generate needed foreign exchange to industrialize the existing labor force. For receiving countries, migration presents a clear way to fill those jobs that nobody wants and to overcome 
critical labor shortages (Piore 1979; Sassen 1988; Portes and Rumbaut 2006). Such explanations of migration provide a starting point for the analysis of the origins and maintenance of migration flows; however, these often fail to consider the relationship between migration and other important characteristics of the migration process, including policy implications, social and human capital available to immigrants, or the human toll involved in the migration process.

According to the neoclassical perspective, labor migrants' attraction for moving to the U.S. can be attributed to the relative difference between the levels of wages in North America to those at their home countries (Piore 19979; Lucas 1983; Portes and Rumbaut 2006). An international wage gap is said to generate incentives for households and families of modest means to explore themselves the migration alternative, which when combined with the establishment of migrant networks and strong demands for manual labor in U.S. labor-intensive industries, creates the impulse necessary to sustain the flow of migration. For U.S. employers, the wage gap often provides justification to cheat their workers, since they may be aware that even when paying below minimum wage, the workers will conclude that they are still better off than at their home country (Waldinger 2003). In addition, willingness to work for low wages and no benefits, along diligence and motivation, makes these workers particularly desirable to employers of a wide range of economic activities in agriculture, manufacturing, and services that rely on and profit from this supply of "cheap" labor (Portes and Rumbaut 2006).

The gravitation of labor migrants toward labor-intensive industries that offer low wages and no benefits has also been understood within the context of a segmented labor market, where particular types of jobs are associated with distinctive types of workers (Piore 1979; Waldinger 2003). While some of these jobs are reserved for natives and characterized by capital intensive factors, which require less labor, others 
are reserved to immigrants or women based on racialization and arbitrary conceptualizations of who is "best" fit for a particular type of job (Waldinger 2003). Such divisions of the labor market are said to create ideal conditions for an immigrant labor force entrenched in the production of dead-end jobs and precluded from accessing jobs in high end sectors, while institutionalizing two classes of workers (Mahler 1995).

In many ways, the polarization of the labor market with its tendency to allocate labor migrants to marginal sectors of the economy has continued despite increases in unemployment and de-industrialization at the hand of economic restructuring of the last three decades. De-industrialization came accompanied by increased levels of overseas outsourcing and a measurable loss of middle-income jobs in manufacture in the United States (Sassen 1990; Mahler 1995; Portes and Rumbaut 2006; Shelley 2007). Such phenomenon, embedded in a basic contradiction between the existence of labor shortages and unemployment, has resulted in the creation of labor-intensive jobs at the bottom of the labor market, while encouraging immigrants from developing countries to participate in a labor market that is largely unattractive to the native-born middle class. As a result, employers of labor-intensive, low wage workers benefit from: (1) a flexible workforce that is willing to work uncomfortable hours and is willing to use hazardous equipment in substandard workplaces; and (2) an organizational flexibility in which workers can easily be disposed of when they are no longer needed or they complain too much (Sassen 1988).

The reproduction of such forms of unsecured jobs presupposes the relative powerlessness of immigrant workers in industrialized countries where labor has obtained some considerable power and were native workers become politicized, are unwilling to take undesirable jobs, and have access to welfare benefits as an alternative to low wage jobs (Freeman 1979; Sassen 1988). These notions about the role of labor migration 
within the context of dual or segmented labor market reinforce the perception that migrant labor is not used merely as a supply of labor, but specifically as a supply of cheap labor (Portes and Walton 1981). In addition, the surplus of labor created in the process benefits employers by enabling them to dispose of workers who protest, strike, or attempt to improve working conditions at the workplace and replace them with workers willing to accept inferior working conditions (Griffith 1993; Chomsky 2008).

These and other salient factors are clearly embedded in the relationship of economic activity and the allocation of workers to specific segments of the labor market where they may become vulnerable to adverse labor conditions. Specifically, as economic activity is closely linked to cultural, political, and social phenomena, attention must be given to the role that certain characteristics of the immigrant labor force play in their inhibited abilities to find jobs (Griffith 1993). One such example is made apparent by workers that are semi-proletarianized - that is they survive on a combination of jobs in the labor market and small-scale subsistence activities such as peasant farming and fishing - since they may be less willing to complain about unfair wages or working conditions due to the short nature of their participation in the market economy (Piore 1979; Griffith 1993). This condition has proven particularly harsh for peasant labor-migrants, as they may consider the nature of the wage-work temporary and become more desirable and more exploitable workers in the developed capitalist economies (Griffith 1993).

For immigrant workers, this situation may result in continued hardships, since they could also be affected by factors such as legal status, race, ethnicity, gender and other individual and social characteristics (Griffith 1993). Although these conditions alone are seldom the primary motivators for worker exploitation, the research available does seem to point out that economic factors as well as immigrant characteristics may play a determinant role. In the case of legal status, Chiswick (1998) demonstrated that 
undocumented immigrants were not any more likely to be exploited than their documented counterparts, with short length in the country being a stronger determinant. However, it has also been shown that undocumented immigrants' vulnerability arises from constant fear of detention and deportation, which gives employers the ability to blackmail workers (Clavita 2005). In addition, as shown by Stepick (1998), low levels of human capital - that is education, work experience, or other skills - as well as prejudice and discrimination from dominant groups may influence particular groups to remain at the bottom-end of the labor market.

Helpful as they may be, models that emphasize the economic characteristics of individuals and the market, fail to provide a comprehensive picture of the role that factors such as solidarity and capital accumulation play within the equation of immigrant incorporation. A different approach sought to illustrate that not all immigrant incorporation occurred under the functions of a split or segmented labor market. To this end, the literature on "middleman minorities" explicitly addresses the issues of ethnicity and economic incorporation by focusing on immigrant entrepreneurship and its relation to the retention of strong ethnic communities within the host society.

The concept of the ethnic enclave as a distinct mode of immigrant incorporation presents the idea that certain groups respond to dominant capitalism by creating their own capitalist system, which could protect them from the risks of the open labor market. Ethnic enclaves consist of immigrant groups that concentrate in particular geographic locations and participate in a variety of enterprises that serve their own ethnic community, as well as the general public (Portes 1983). In this sense, ethnic enclaves allow immigrant labor to be reproduced through the hiring of co-ethnics by immigrant entrepreneurs. Through social ties, ethnic enclaves may provide privileged access to resources; however, they can also act to restrict outsiders from gaining access to 
available resources through particularistic or preferential treatment (Portes 1998;

Waldinger 2003). The establishment of a Cuban enclave has been widely observed in South Florida where it has often meant restricted labor and economic opportunities for other immigrant groups and minorities (see Portes and Stepick 1993; Stepick, Grenier, Castro, and Dunn 2003).

The enclave economy model highlights the relationship between economic activity and the social relations and structures from which it emerges (Schmitter Heisler 2000). Central to this issue is the principle of social capital, which is broadly defined by Portes (1995:12) as the "the capacity of individuals to command scarce resources by virtue of their membership in social networks or broader social structures." For Portes and Sensenbrenner (1993), social capital is characterized by a series of expectations for action within a collectivity that affect the goals-eeking behavior of its members within the economic sphere. For Waldinger (2003) this may come to represent limited access to resources for outsiders once a particular ethnic group has secured access in a particular labor market or industry.

In recent years, the development of a comprehensive theory of migration has sought to include the distinct contexts that trigger migration at the sending country as well as the many ways in which immigrants become incorporated into the political economy of the receiving country. In essence, a better integrated perspective of international migration should involve issues of mobilization, transportation, the utilization and manipulation of the immigrant labor force within the political and institutional establishment, and the networks that allow immigrants to obtain economic advancement (Portes and Walton 1981). The "new economics of migration" framework serves to better explain the process of migration by focusing on the household rather than on the individual as the unit of analysis in the decision-making process involved in migration (Portes and Rumbaut 
2006). As it has been shown, labor immigrants must deal with housing transportation and other issues associated with their lives at the host country as well as with a variety of economic pressures to attend at their home country (Griffith 2006; Shelley 2007). Because of many of the aforementioned issues, many workers' may often decide to remain with an unscrupulous employer or to withstand different forms of exploitation since they are subjected by pressures to send money home to pay for loans, children education, or the construction of a house.

Portes and Rumbaut (2006), thus argue that migration and incorporation must be viewed in light of a variety of factors that include the demand for labor migration in a context in which,

Demand exists at the bottom of the labor market for menial, low paying jobs and, higher levels for professional and technical occupations in short supply in the nation... Second, labor demand must be made known. In earlier periods, the "higher wages and better meals" paid for work in American Industry were not enough to activate a labor flow so that paid recruiters had to be sent abroad to apprise foreign workers and peasants of those facts... To these developments are added the social networks built by immigrants themselves that can act as human transmission belts, conveying information about job opportunities... Third, the opportunities must be desirable. Desirability is less a question of the gross earnings of disparity between sending and receiving countries than of the meaning that these economic disadvantages have for households and communities.

Thus, in addition to understanding economic factors, the characteristics of immigrants, and the socioeconomic pressures they must experience along the migration chain, this view adds weight to the role that preexisting networks play on the patterns of location among labor migrants, as they are no longer guided by recruitment efforts, but by the presence of family and kin already located in the receiving country. Together, these factors provide a more complete picture of the conditions that affect immigrants' working conditions as they stride to improve their economic standing within the world's globalizing economy. 
A thorough analysis of the conditions of immigrant incorporation, exclusion and exploitation, must include the effects that immigration policy and enforcement have on the location patterns of immigrant groups as well as on the process of economic incorporation into the host society. In the following section I review a number of discourse and policy ramifications for labor migrants and their effects of marginalization and worker vulnerability.

\section{Immigration Policy and Regulation in the U.S.}

Coinciding with the resurgence of large-scale immigration to the United States in recent decades, immigration and immigration policy issues have become hotly contested in the public arena of the nation (DeWind and Kasinitz 1997). However, a closer look at the history of the country's policy and public discourse demonstrates that the United States has continuously struggled with the social and economic "impact" presented by the large influx of immigrants (Hayes 2001; Hing 2004). On one side, the public sphere has often responded to negative outcry during nativist periods fueled by rising unemployment and fears of national security (Kretsedesmas and Brotherton 2008). On the other, labor shortages and rapid economic expansion have created popular acceptance for the need and influx of immigrants. From an academic perspective, the discussion should bear the questions of what drives immigration policy, and what is its impact on the relationship between the social structures and individual actors that it affects

In this section, I discuss two important aspects of U.S. immigration policy and focus on the implications that they have on the reproduction of exclusion and inequality for millions of foreign born workers. First, I discuss the disconnect that exists between recent structural changes at the transnational economic level and the formulation, implementation and enforcement of U.S. immigration policy. I also discuss the negative 
effects that immigration policy has had for the labor conditions of migrants, while benefiting and protecting the business interests that employ them.

\section{$\underline{\text { Closing Borders in the Era of Open Markets }}$}

In the United States, immigration policy and the public discourse that surrounds it are understood from an individualistic perspective, unconnected to historical events or current actions of receiving countries in an approach that portrays the state as a humanitarian actor, which passively receives migrants in need (Sassen 1999, Portes and Rumbaut 2006). Such widely held perceptions may help to explain the failure and limited effectiveness of current immigration policies, which emerge as a result of the short-sightedness between the realm of migration and broader structural changes taking place within the international economic arena. This framework is perceptually misunderstood by policymakers in receiving countries, making enforcement and policy evolve around individual agency as the main mechanism for immigration (Sassen 1998; Massey, Durand and Malone 2002). Central to this issue is evidence that migrations occur as a result of dynamics within the geo-political system, where the major receiving countries tend to receive immigrants from their zones of power (Sassen 1999). For the U.S., a renewal of mass migration emerging in the 1960 s has been largely influenced by an increase in economic, political and military activity in developing regions of Asia, Latin America and the Caribbean Basin (Sassen 1998, Kritz and Gurak 2004). The continuation of these policies through the remaining part of the 20th century led to a formalization of transnational economic policies demonstrated by the creation of a variety of free trade agreements and larger supranational bodies of enforcement, where labor continues to be separated from the transnational process, and regulated by national actors (Sassen 1998). 
The contradiction between the formalization of a transnational economic system and the existing migration policy frameworks is now recognized as problematic and was made evident through the establishment of GATT, NAFTA, CAFTA and other free trade agreements around the world (Sassen 1999; Massey et al. 2002). These treaties have had to treat the flow of people as an integral part of free trade and investment across international borders; however, they have disconnected the notion of migration from the broader process of globalization by narrowly focusing on the circulation of specialized service workers and business people as means to further internationalize trade and investment services (Sassen 1998). In this sense, immigrant reforms and policy efforts concentrate on the admittance of professionals, displaced refugees and their family members on one side, and the rejection, detention, and deportation of unwanted "illegal" migrants on the other (Kritz and Gurak 2004). Ultimately, the result is that while business, trade and finance transcend national borders and loosen up to traditional demands of state sovereignty, labor remains a space where states strongly exercise and negotiate control, regulation, and policy implementation.

On a positive side, the formalization of free trade through the establishment of enforcement bodies has brought about new enforcement regimes that legitimize the processes under which states must respect and enforce international human rights codes regardless of nationality or legal status (Sassen 1999). Formalization occurs through the relocation of a range of components of state authority to supranational organizations such as the European Union (EU), the World Trade Organization (WTO), or international human rights courts in which legal regimes become positioned to enforce cross-border business, financial transactions, and some forms of labor mobility (Sassen 1998). However, in terms of immigration policy and enforcement, deregulation has also meant an increase in the actors and levels of enforcement that those actors have 
acquired within the state (Sassen 1998). At the state level, this has resulted in a fragmentation of how enforcement of immigration policy should be conducted.

In recent decades, for instance, there has been an increase in the independent efforts by U.S. member states (e.g., California, Arizona, Alabama) to regulate so-called illegal immigration or to recover expenses from the federal government, under the argument that undocumented immigrants are an economic burden to states' budgets (Glick Schiller 1994, Sassen 1998, Hayes 2001). These attempts have materialized in the enactment of laws such as California's proposition 187, which sought to prevent undocumented immigrants from receiving health services and education, or recent lawsuits by several states against the federal government to collect money from the imprisonment and the use of services attributed to undocumented immigrants (Glick Schiller 1994, Sassen 1998). In many ways, the process is embedded in two distinct frameworks created by the same contradictions present in the policy and economic restructuring of the last three decades. First, U.S. states find justification to their arguments by citing the notion that the federal government, while creating the migration policy for the country does very little to enforce it, thus leaving them with the burden of providing health services, infrastructure, and education to undocumented workers. Second, the process is embedded in a "devolution" of power from the federal to the state level, which is consistent with the same trends in deregulation necessary for the establishment of a globalized economic system (Sassen 1998).

The biggest change in the implementation and enforcement of immigration policy, however, was brought about by the attacks of September 11, 2001. These tragic events have helped to sustain the current discourse and practice of US immigration policy and regulation around the issue of national security (Kretsedemas and Brotherton 2008). Although a shift toward more deportations and higher spending on immigration 
enforcement existed several years before $9 / 11$, those tragic events served as a turning point in the public discourse surrounding the immigration issue. This change reflects a desire for power that is only superficially tied to national security and which justifies the mistreatment of unfavorable groups by constructing judgmental labels around them. The result has been a downgrade of immigrant rights in a way in which restrictions for the rights of terrorist suspects become the same restrictions for the legal rights of immigrant detainees as well as of asylum seekers (Dow 2008).

These issues have resulted in a variety of efforts at the local, state, and federal level to curtail migration and include: (1) increased militarization of U.S. borders, specifically on the Mexican-U.S. border, as well as the construction of a wall dividing both nations; (2) the use of scare tactics to scare immigrants out of the United States through mass deportations, family separation, the criminalization of undocumented workers, and the use of local law enforcement agencies as immigration agents, and; (3) the proliferation of grassroots, militant, anti-immigrant organizations, such as the Minuteman militia, throughout the country (see Kretsedemas and Brotherton 2008; Massey et al. 2002).

Ironically, the intensification of the individual as the focus of migratory enforcement has coincided with an era in which the United States has become increasingly reliant on immigrant populations for workforce replenishment and population growth (Kretsedemas and Brotherton 2008). Together, these conditions have created the current trends in immigration enforcement that renders immigrants unprotected and vulnerable to unfair labor practices as well as unprotected by the law and unqualified to receive basic human services such as education and medical treatment.

Regardless of policies and propositions aimed at regulating the flow of "undesirable" immigrants into the country, national legislature has continuously ensured formal exceptions for the admission of temporary foreign workers (Hayes 2001). This 
demonstrates an ambivalent framework, where official immigration policy acts as a mechanism that facilitates and regulates the supply of labor through border enforcement while rendering undocumented immigrants, socially and politically powerless (Sassen 1998). In this sense, immigration policy acts as labor policy, benefiting businesses interests with a steady supply of "cheap" labor, even when a large labor surplus exists, while counteracting the organizational efforts of domestic workers (Portes and Walton 1981). As Portes and Walton (1981) explain, the price of migrant labor is not predicated upon the process of migration or on personal attributes of the migrants, but rather it is the result of deliberate political manipulation. In the U.S., such political manipulations result from the collective and competitive power that capital has been able to achieve through powerful and heavy representation in Congress.

There is a logical fit between the labor needs of US employers and the presence of undocumented workers, which reveals a deliberate political manipulation to supply important sectors of the employer class with a supply of cheap labor. U.S. immigration policy explicitly bans the use of undocumented labor through a series of restrictions embedded in a "historical bargain" between the state, capital, and labor; however, the short supply of cheap labor places firms and industries at a disadvantage (Portes and Walton 1981). In that case, the use of low-wage immigrant labor can be seen as a supply system for employers that seek cheap labor that is necessary for the organization of labor around shift work, hazardous conditions, and job insecurity (Sassen 1988). At the policy level, firms and industries are able to maneuver the political machinery through heavy representation in the U.S. Congress, securing a profitable supply of disposable, vulnerable, powerless, exploitable, and disenfranchised class of workers (Portes and Walton 1981; Sassen 1988). 
Portes and Walton (1981: 57) argue that intentional state manipulation for the use of undocumented labor involves three conditions:

(a) that the criminality of illegal entry be maintained so that workers are kept in a situation of vulnerability, but that their employers be made legally immune; (b) that the credibility of the threat of deportation be maintained through the action of repressive agencies, but that these agencies do not become so effective as to interfere with the flow of illegal labor; and (c) that political authorities in the country where immigrants originate are appeased, but that their efforts to give immigrants legal protection and increase their wages (part of which are always repatriated) be neutralized.

The relationship between deliberate political manipulation and the labor needs of employers has been clearly visible through the history of U.S. agribusiness and its dependence on low-wage, foreign born labor. I now turn to the case of agricultural labor in the U.S., to demonstrate how some of the aforementioned structural and policy implications have and continue to guarantee a steady supply of low-wage workers for the agricultural elite class, while creating dangerous conditions for the exploitation, exclusion, and marginalization of the immigrant labor force.

Guaranteeing the Supply of "Cheap" Labor: The Case of Agricultural Labor in the U.S.

The use of Mexican labor in California and the Northwest can be traced to the late 1800s, and resulted from agricultural improvements in the development of vast irrigation systems and railroads, which linked agriculture to financial and banking institutions (Gamboa 1990; Stephen 2007). The shift to intensive crop production created a need for a flexible agricultural workforce that would be willing to work for low wages and that could be easily manipulated to grower and industry demands (Stephen 2007). Worker compliance was facilitated through the use of political threats of deportation to workers, who were already weakened by their status in relation to the state (Portes and Walton 1981). This phenomenon became linked to immigration policy, creating the current model, which is essentially labor policy masking as an immigration policy (Stephen 
2007). In this sense, immigration policy merely functions to control the amount of labor available to businesses, relaxing enforcement according to industry needs and strengthening in periods of economic downturn or public outcry about undocumented immigration.

Despite strong opposition by organized labor, temporary worker programs were enacted to continue the flow of "cheap" labor and particularly to provide agribusiness with a constant supply of workers, mainly from Mexico (Hayes 2001). Early forms of temporary worker programs were established beginning in 1917 to relieve labor shortages during WWI. Thousands of Mexican immigrants continued to be imported throughout the 1920s; however, during the great depression, massive deportations were reported throughout the Southwest and Midwest. These were enforced by the immigration service as well as by state and local authorities (Stephen 2007). The situation changed again by the end of the Depression, and when harvests came around, U.S. growers dispatched their emissaries to Mexico, recruiting and bringing thousands of workers into the country (Stephen 2007). The 1917 program laid the foundations of the Bracero Program established during WWII, which sought an agreement with Mexico to alleviate agricultural labor shortages.

The bracero program was designed to fill labor shortages during WWII; however, despite the program's plan to bring a "regulated" labor force into the country, thousands of undocumented workers continued crossing the border through the 1950 s and the mid60s when the program was shut down (Stephen 2007). Ironically, the program was not part of the overall U.S. immigration policy, falling instead under general congressional legislation, and having been extended on a yearly basis under considerable pressure from the Texas and California delegations (Hayes 2001; Massey et al. 2002). The bill gave control of protections and programs such as wage regulation, health insurance, 
housing, and transportation to U.S. employers, and although the contracts were originally carried out between the U.S. and Mexican governments, they were later privatized, creating unintended consequences for the increase of undocumented migrants in the country (Hayes 2001). As Stephen (2007:74) argues, growers often "preferred indocumentados to bracero workers because they could be paid even less than braceros, could be encouraged to remain for as long as necessary, and, like braceros could not organize or pursue collective bargaining agreements." In addition, the program incurred no liability for employers under the US immigration law. For instance, the "Texas Proviso," written by the Texas Congressional delegation, prohibited persecution to employers who hired undocumented workers; thus, creating a loophole through which growers could simply spread the word among their braceros that jobs were readily available to friends and relatives who choose to come (Massey et al. 2002).

Mexican migration commenced to decrease by the end of the bracero program, fueled in part by deportations, the organizing of farmworkers in California, and by the extension of labor laws that conceded farmworkers the right to organize and join unions through the Agricultural Relations Act (ALRA) of 1975 (Stephen 2007). Despite such advances in the working conditions of farmworkers, agricultural union membership declined drastically into the 1980s, and growers again turned to labor contractors to recruit directly from Mexico (Stephen 2007). Logically, U.S. growers could have drawn native workers back into the agricultural labor force; however, such a move would have entailed a significant rise in wages, a rise in prices, and induced structural inflation (Massey et al. 2002). In addition, after a long period of monopoly by Mexican labor, agricultural work in the United States had become severely racialized and defined socially as "foreign," particularly Mexican, and growingly unacceptable to US citizens (Massey et al. 2002). In the aftermath of the bracero program and the 1965 changes in 
the immigration law, enough Mexican population had settled in the country, creating a significant stock of migration-related social and human capital, which helped spark a steady growth of Mexican migration into the country.

In 1986, the Immigration Reform and Control Act (IRCA) sought to prevent future streams of undocumented migration into the country by legalizing millions of undocumented workers and by sanctioning employers who hired undocumented workers (Hayes 2001; Stephen 2007). With the passing of IRCA, legislators believed they had put together a compassionate bill that would legalize much of the undocumented population, while shutting the door on future undocumented migrations (Hayes 2001). Although the legislature attempted to treat the problem from the source, that is targeting businesses that were supplying jobs to undocumented immigrants for low labor costs, it only resulted in the creation and intensification of a silent, vulnerable underclass jeopardized by public policy (Hayes 2001). IRCA created several problems to those who were not legalized since,

The undocumented who were not accepted for legalization were then deprived of the right to work and therefore were deprived of the means to sustenance. In addition they could be subjected to exploitation by unscrupulous employers since they have no legal recourse, do not have full protection under the law, and under IRCA's stipulation, all federally funded social services require proof of legal status as a prerequisite for obtaining services (Hayes 2001: 7).

In addition, the new policy had profound effects on the immigration patterns that emerged after the reform.

Thus, since the country's immigration policy gives priority to family reunification, the status regularization of three million undocumented immigrants led to an increase of applicants and migrants coming from the south. It is estimated that a great number of undocumented immigrants also came into the country following some of the migrants who were being claimed through legal resources, adding to the already large number of 
undocumented immigrants in the country (Stephen 2007). In addition, one of the most important aspects of the growth of undocumented migration in the post-IRCA era was the sanctioning imposed to employers who hired undocumented labor, which resulted in an increase of labor subcontracting, where contractors hired undocumented workers and charged companies for "services," rather than having large companies hire the workers themselves. With this practice also came increased abuse in the agriculture industry and increased opportunities for undocumented workers to find work (Stephen 2007). As Stephen (2007:76) argues, "While the reforms in IRCA were supposed to improve farm labor conditions, the result was often the opposite, as undocumented first-time immigrants are least likely to question the practices of labor contractors and are also highly dependent on them for off-farm housing, rides to work, false work documents, and food."

The conditions that underlie the exploitation of Mexican migrants are clearly embedded in a process of reproduction of capitalist relations with a general participation of the state (Sassen 1988). However, the phenomenon is not limited to the agricultural industry, as growing sectors participating in this process include goods-producing industries such as meat packing, auto making, construction, and a growing number of service jobs (Portes and Walton 1981). Together with the changes taking place at the transnational level, the ambivalent current state of immigration policy continues to contradict the process of neoliberal restructuring set in motion in the last decades of the 20th century. These policies are also at odds with labor regulations and policies that guarantee the rights of workers, creating the right conditions for the exploitation of the immigrant labor force. The following section, describes the nature and the extent of wage theft across a variety of job sectors and industries, focusing on low-wage workers 
and their vulnerability to become victims of wage theft in a system that offers little legal recourse or opportunity for remuneration.

\section{Wage Theft}

On July 15, 2008, the Committee on Education and Labor of the U.S. House of Representatives held a hearing on the Department of Labor's (DOL) enforcement of wage and hour laws. At the meeting, Kim Bobo, director of Interfaith Worker Justice (IWJ), an organization that engages the religious community around issues and campaigns to improve the wages and working conditions of workers, testified about the poor work performed by the DOL to stop the growing cases of wage theft around the country. Bobo claimed that two million workers are not receiving at least the minimum wage, while three million others are miss-classified as independent contractors, and millions more are unlawfully denied overtime pay. The hearing prompted an editorial from the New York Times, which cited the way in which the Wage and Hour Division of the DOL had failed to adequately investigate and address worker complaints (July 18, 2008). Like the New York Times, a variety of newspapers and other independent news sources throughout the country continue to address issues of wage theft throughout a variety of mostly low-wage industries. Although several scholars have reported the occurrence of wage violations in immigrant communities (see Mahler 1995; Stepick 1998, Pisani and Yoskowitz 2002; Ness 2005; Fine 2006; Stephen 2007, Bobo 2009), to date, few authors have addressed the issue in depth with only one author treating the issue from a structural perspective (See Bobo 2007). In this section, I begin to lay the groundwork for how and where wage theft is prone to occur, using a variety of news sources and reports as well as a growing, but limited, number of academic sources that are beginning to analyze the problem. 
In many ways wage theft is a new term that defines an old phenomenon. Most of the recent literature concerning economic exploitation of workers has dealt with the issue in terms of wage and hour violations and in some very drastic cases included the occurrence of modern forms of slavery. Wage theft refers to the lack of payment of a worker's partial or full salary through systematic or unintentional action. More specifically, "wage theft occurs when workers are not paid all their wages, workers are denied overtime when they should be paid it, or workers are not paid at all for work they've performed (Bobo 2009; 7)." Because wage theft often impacts low-wage, immigrant workers, its effects contribute to worker poverty, their increased marginalization, and an array of socio-economic pressures on their families in the U.S. and abroad. In addition, wage theft undermines the integrity of business by creating an unfair advantage for those employers that cut costs by squeezing their profits out of their employee's paychecks. Finally, by underpaying and underreporting employee earnings, employers cheat federal and state taxation laws that contribute to public infrastructure.

The Fair Labor Standards Act (FLSA) was enacted in 1938 to abolish child labor in manufacturing, to guarantee a minimum wage, and to establish the 40-hour workweek as the national norm. Although the FLSA has been amended on several occasions since its conception, it has clearly not been able to keep up with the transformations that the economy has undergone in its now 70 years of activity (Fine 2006). FLSA contains a number of provisions through which the minimum wage requirement should be enforced. First, a worker or a group of workers can sue their employer for unpaid back wages and an equal amount to liquidate damages; second, the wage and hour division of the DOL can inspect companies' payroll records and sue the employer for unpaid back wages or overtime; third, the DOL can fine an employer who willfully break minimum wage and overtime requirements; fourth, the DOL can bring criminal charges against employers 
who violate the law. Unfortunately, while the workforce and enforcement coverage have grown, resources for enforcement have steadily declined (Fine 2006).

Throughout the country, wage theft has been known to affect workers in predominantly low-wage, labor intensive, immigrant industries (see Greenhouse 2004, Lee 2005, Margolies 2005, Hunsburger 2006, Miller 2004 and Pemberton 1998; Bobo 2009). In systematic cases of wage theft, time cards or time records are known to be manipulated by management personnel in a procedure commonly known as "shaving time," where employees' weekly hours are reduced through computerized payroll systems. Other cases include pressuring employees not to record all their working times or to performing chores "off the clock" (Greenhouse 2004, Lee 2005, Margolies 2005, Miller 2004 and Pemberton 1998). Many of these practices include depriving workers of overtime wages, paying them under the legal minimum wage or, in more voracious cases, simply not paying workers for their labor (Hunsburger 2006 and Miller 2004). Although many of the documented cases of wage theft occur through intentional action, it has also been reported that ignorance of wage and labor standards by both workers and employers is known to exacerbate the conditions for wage theft to occur (Brennan Center for Justice 2006; Bobo2009).

One of the most significant problems faced by immigrant workers is lack of awareness of their rights as well as lack of knowledge of where to seek help. For undocumented workers, fear of "outing themselves," arrest, or deportation often prevents them from seeking the help they need to assert their rights. In fact, undocumented immigrants are covered by the same labor rights given to US citizens, however, federally funded services are required by law to turn them away if they come in seeking help (Fine 2006). 
In terms of industry, systematic unlawful patterns of wage theft have been exposed by several class action lawsuits filed against retailers such as Wal-Mart, Toys "R" Us, Pep Boys, Family Dollar and Taco Bell (Greenhouse 2004, Lee 2005, Margolies 2005 and Miller 2004). In the hospitality and service industries wage theft has been documented in restaurants and hotels that pay wages below federal standards, or that fail to pay for overtime hours. Around the country, waiters, waitresses, chefs, and maids often find their tips retained by their employers or are paid below the legal standards for tipped employees (Johnson 2005; Marks 2005; Hunsburger 2006; Bobo 2009). Some reports account that up to 98 percent of restaurants in L.A.'s Koreatown were not paying minimum wage (Fine 2006).

In construction, workers often find themselves receiving lower wages than promised or not being paid time-and-a-half for overtime wages, a condition that undermines the federal standards for wages (Egelko 2005). Similarly, in agricultural and forestry work in the United States, where pay tends to be low and employers are not legally required to pay additional compensation for overtime hours, workers are often paid under federal minimum wage standards (Renford 2001; Bobo 2009). A great number of agricultural and forestry workers are immigrants from Mexico and Guatemala, who find themselves without legal resources and marginalized by their language and lack of "legal" migratory status. As Fine (2006) explains, in California, Several cases of wage theft brought to the DOL were rebuffed under the misguided premise that undocumented workers or workers working under the table were not elegible to file claims. The situation has been exacerbated by the unavailability of Spanish translators to aid in the cases, by settlements with employers that allowed for only 50 percent of what was owned, and by the DOL's decision to go back only two years, when the statue of limitations provided up to six years to investigate cases. 
Also vulnerable are those workers who participate in the informal economy. These often include day laborers in construction and agriculture, and domestic workers. Day laborers are mostly hired by contractors and individuals to perform small-to-medium jobs in private homes or in industries that require additional short-term labor. After performing their work, their employers often abandon them at sites or simply refuse to pay the workers (Gonzalez 2006 and Walsh 2006). Domestic workers are usually maids and caretakers of children or the elderly in private homes. Domestic work is mostly unregulated and creates tempting conditions for employers to indulge in forms of wage theft. Pisani and Yoskowitz (2002), for example, found that the average hourly rate for maids working in a Texas border locality was $\$ 3.44$ for day maids and $\$ 2.61$ for live-in maids - rates considerably below the U.S. national minimum wage of $\$ 5.15$ at the time of the study. Domestic workers are excluded from the National Labor Relations Act (NLRA); however, they are covered by state and federal regulations, including minimum wage provisions under the FLSA. Unfortunately, many employers are unaware of their legal obligations, leaving domestic workers unprotected and powerless against unscrupulous practices (Fine 2006).

Wage theft is a complex issue, where several factors interact to create the conditions that allow employers to take advantage of workers. As Ness (2005) argues, wage theft has become one of the most severe forms of worker abuse in New York's apparel industry, where over $40 \%$ of the immigrant driven workforce reports having suffered some form of wage violation. The evidence already mentioned in this section, shows that wage theft often targets segments of the workforce where new immigrants with low skills, no documents or work permits, and no knowledge of agencies that could help, abound. These often transient immigrants fall outside the state policies established to control abuse as well as the labor institutions that traditionally help workers balance 
power with their employers (Ness 2005). This poses a difficult challenge for worker organizing, since it requires the creation of new institutions as well as new strategies for collective mobilization (Milkman 2000).

\section{Organizing Immigrants}

Several authors have argued about the importance of organized labor to combat poor working conditions and substandard wages of immigrant workers in important labor markets of the U.S. (see Nissen and Grenier 2002; Milkman 2002; Martin 2003; Ness 2005; Fine 2006; Bobo 2009). However, union efforts to organize immigrants have not always been successful, particularly as a result of factors in the structure of unions and their hostility to include immigrants in their organizations (Nissen and Grenier 2002; Milkman 2002). In other cases, poor immigrant response to unions resulted from corporate interests taking advantage of deregulatory economic policies and of unenforced migratory policies that allow them to bypass unions and union tactics in favor of employing an undocumented, low-wage, vulnerable workforce (Martin 2003).

Undocumented workers are even more vulnerable, as they have fewer rights and protections if fired because of organizing activities, while fear of losing their job is an understandable barrier to join a union when as many as 52 percent report being threatened with calls to immigration officials during organizing drives in which they are included (Fine 2006).

Despite such conditions, a variety of organizing efforts have emerged throughout the country, responding to the needs of immigrant workers through worker and community organizations (Ness 2005). In this section I focus on the issue of immigrant organizing by looking at the historical relationship between unions and immigrants; their increasing efforts to organize the growing immigrant workforce of the country; and the emergence of grassroots, worker, and community organizations, which concentrate immigrant 
collective action around a variety of issues including, but not limited to, worker rights, worker solidarity, empowerment, and education.

\section{$\underline{\text { Unions and Immigrants }}$}

Since the beginning of the 20th century, several unions tried, rather unsuccessfully, to organize immigrants in the U.S. labor force. The lack of success in immigrant organizing has been partly explained from two different perspectives. First, many attributed the lack of immigrant participation in unions to issues relating particular characteristics of the immigrants themselves, citing the way in which immigrant labor was entrenched in unskilled occupations, and in tightly knit networks, which separated immigrants from the mainstream American life (references). However, a look at the historical relationship between American labor and immigration reveals a second perspective, which is based on racial and ethnic exclusionary practices on behalf of the US labor movement. At the heart of the issue are traditional structures, maintained by groups of ethnic whites resisting change in union membership and organization (Nissen and Grenier 2002). For Milkman (2002), the fact that immigrant workers rely heavily on close knit networks makes them easier to recruit into the labor movement, a key resource for building labor solidarity, particularly when unions identify and recruit key leaders of the community. Although, the transnational nature of the current economy has facilitated the implementation of anti-labor practices by making organizing difficult for most of the existing unions (Milkman 2000), the growing immigrant nature of the country's work force has forced unions to rethink their organizing strategies in order to avoid extinction (Nissen and Grenier 2002).

Achieving the task of rebuilding the US labor movement demands an effort to reach out to the extensive and growing immigrant working-class population (Milkman 2000). Today, one out of eight workers in America are first-generation immigrants of which, one 
in four are low-wage workers (Fine 2006). At the national level, immigrants are underrepresented among union members, suggesting that at the low end of the work spectrum, unionization may provide little appeal to low-wage workers, especially if they are part of circular migration streams as they may be the most exploited members of the immigrant workforce (Waldinger and Der-Martrosian 2000). Waldinger and DerMartrosian (2000) found that immigrants who had been in the country for less than 10 years were less likely to be unionized, while those living in the country for over 20 years, were four times more likely to join a union. However, the study's most significant finding is that immigrants' attitudes and propensities toward unions are not necessarily based on individual feelings about the union, but rather on whether a worker is employed in a workplace where a union exists. Such conditions pose important limitations to immigrant organizing, as recent immigrants are effectively excluded - by language and citizenship requirements - from public sector employment, which still provides high levels of unionization, and by the fact that nine out of ten jobs in the private sector are nonunion (Waldinger and Der-Martrosian 2000).

Beginning the 1990s, major efforts to organize the immigrant labor force have emerged from the ranks of several key unions around the country (see Nissen 2002, Milkman 2000, Ness 2005). Unions that think strategically about immigration and migration issues and that put programs in place to improve education, leadership, structural flexibility, and intercultural interaction are more likely to succeed in today's growing immigrant environment (Nissen, and Grenier 2002). Similarly, since 1995 leadership of the AFL-CIO began pouring unprecedented resources into their immigrant organizing efforts, announcing in 2000 a new policy initiative, which would give amnesty to undocumented workers and would lift sanctions against them and those employers that hire them (Milkman 2002). These efforts have also consistently emerged from the 
ranks and efforts of immigrant workers themselves which, once organized, established unions see as an opportunity to include within their strategic plans (Ness 2005). These forms of worker organization have responded to isolation and limited social networks experienced by new immigrants working together under harsh conditions, and channeled by color, ethnicity, language, religion, and nationality into the expression of solidarity and militancy (Ness 2005). In many cases, workers in specific firms and industries have carried out their own strikes and organizing drives, calling the attention of the labor movement and the community and allowing specific unions to bring in their expertise to successfully winning a first contract (Milkman 2000).

\section{Farmwork and Unions}

During the 20th century, farm labor reformers hoped to make their labor market more like non-farm labor markets. This meant that farm employers could invest in personnel departments to recruit the best workers, motivate them, and retain them with seniority and fringe benefits. Union hiring halls could handle recruitment and wages could be determined through collective bargaining (Martin 2003). These hopes began to materialize in 1975, when California enacted the Agricultural Labor Relations Act (ALRA), which granted farmworkers the right to organize and bargain with employers (Martin 2003). The enactment came under pressure from Caesar Chavez and the United Farm Workers (UFW) union, which was predicted to become one of the nation's largest unions; however, during the 1980s and 1990s, union membership dropped to fewer than 35,000 workers in California, or just 5 percent of the persons employed for wages in California's agriculture, ultimately reversing the effects of the original hopes, with employers distancing themselves from workers and turning to labor contractors to recruit workers (Martin 2003). 
Martin (2003) explains the decrease in union membership and thus, power, in the context of larger changes in the political environment, farm employment practices, as well as poor union leadership. First, political changes can be attributed to a dependency that ALRA had on the Agricultural labor Relations Board (ALRB), which is controlled by the governing administration. Thus, from the early years of the Reagan administration, pro-grower governors appointed their political allies to the ALRB, and successfully truncated the efforts achieved by labor during the democratic administration of the late 1970s. Second, large conglomerates such as Shell Oil, and Seven-Up sold their farming operations to smaller ranchers and producers who did not have to worry about unionization and who used contractors for a refreshed immigrant labor force. Finally, poor union leadership may have contributed by not deploying enough seasonal workers, paying pension plans and medical fees late, and thus garnering worker dissatisfaction and reducing support.

Today, at least 75 percent of U.S. farm workers are immigrants, the majority of whom are not authorized to work in the United States. The rate of immigrants among farm workers contrasts greatly with the $12 \%$ of immigrant workers in the nonfarm economy, of which only 3 to 4 percent are unauthorized to work in the country (Martin 2003). On average, farmworkers earn a quarter of the average wages earned by nonfarm workers, a discrepancy that occurs because farmworkers receive lower wages per hour and over all work fewer hours than their nonfarm counterparts (Martin 2003). For farmworkers, the desire to collect higher wages is often embedded in a notion that federal and state governments could do more to help workers join unions and increase wages despite a growing supply of immigrant labor. This is important because conventional economic wisdom would argue that an extended supply of workers results in depressed earnings. However, worker advocates as well as current leaders argue that the real factor 
depressing wages is the workers' fears of joining unions and negotiating for higher wages (Martin 2003). Unfortunately, as Martin (2003: 162) states,

Unions play small and declining roles in the U.S. and California farm labor markets, yet low wages, poor working conditions, and unique features of the farm labor market, including immigration and migrancy, keep farm labor issues in the news, reminding Americans that farm labor is a "problem." Most farm employers continue to believe that unions are neither desirable nor inevitable, and most farm workers continue to exit for nonfarm jobs rather than turn to unions for upward mobility in agriculture.

These considerations are important because as an increasing number of rural immigrants recur to nonfarm work for upward mobility, an endless supply of agricultural immigrants will be needed to replace them as they exit to other forms of non-farm labor jobs.

\section{The Community and the Grassroots; Alternatives to Union Organizing}

In the long run, deregulatory changes at the economic level responsible for relocating protection and services away from the state-operated machinery have also resulted in the growth of NGOs and other types of social organizations that fill the needs left in the absence of the state (Sassen 1998). For the labor movement, deregulation has signified the creation and proliferation of worker self-help organizations aimed to protect the status of workers and their wages as well as developing a variety of programs and initiatives concentrated at the local and at the transnational level (Ness 2005). There has also been an emergence of worker centers and community organizations dedicated to enforce the FLSA as well as state labor laws, to defend the labor rights of undocumented immigrants in court rulings, and to defend immigrant rights in general, by working together with government agencies and departments (Fine 2006).

The work of most community organizations revolves around a social justice frame, which is often accompanied by service delivery to help exploited workers assert their rights, while advocating for long-term policy changes in immigration and labor areas that 
could secure the well-being of the immigrant labor force (Fine 2006). As Jayaraman and Ness (2005) argue, conventional forms of union organizing no longer work in a context where immigrant workers are frightened to speak out for fear of deportation or detention, giving rise to a variety of forms of community organizing based on language, ethnicity or other forms of cultural currency. For Stephen $(2007 ; 236)$,

These types of grassroots organizations are vehicles through which transborder migrants can claim and then strive to obtain a variety of rights that may routinely be denied to them formally through the law (as in the lack of the right of farmworkers in many states in the United States to collective bargaining) or rights that can be legally claimed that are often not respected, because the forms of intimidation

The aforementioned forms of organizations are often embedded in a wide range of issues including "the relations of production and reproduction, the politics of immigration and immigrant rights, culturally based issues such as language and local cultural expression and maintenance, sexism in the workplace and at home, collective memory and connection to communities of origin, and the creation of community across borders and through networks (Stephen 2007; 270)."

As a more specific approach to labor issues, worker centers emerged in the late 1970 s and early 1980 s as a response to deteriorating changes in manufacturing that were accompanied by factory closings, deteriorating working conditions, and the increase of low-wage service sector jobs (Fine 2006). From 2000 to the present, worker centers have multiplied in urban, suburban, and rural areas of the country, responding to a growing concentration of immigrants from Mexico, Central and South America working in the service, meatpacking, poultry, and agricultural sectors (Fine 2006). In general, worker centers have emerged as a result of a declining presence of institutions that historically provided workers with the tools for protection and collective action. Their emergence has also responded to the fast growth of immigrant communities and their 
need to fill the void left by the absence of infrastructure that supports labor and collective needs (Fine 2006).

Worker centers as well as many grassroots community organizations have a longterm social justice agenda, which includes short and midterm goals aimed at policy modification and organizing campaigns (Fine 2006). For Fine (2006; 72-3) most community organizations and worker centers today are engaging in service provisions as a way to legitimize themselves with immigrant workers and the broader community, where the growing number of these services include:

... legal support for pursuing unpaid wages, they do so with great trepidation, because they want to promote collective and systemic approaches to change. They want workers to see that the solution to their situation requires collective action to alter the relations of power and win concrete victories, and worry that helping workers individually cuts against that message and takes time and resources away from that work. They seek to address this dilemma in two ways: by delivering services in a way that empowers workers and by connecting service, as much as possible, to organizing.

As Fine (2006) demonstrates, worker centers around the country consistently resolve cases of wage theft, with success rates of up to 71 percent, while collecting full amounts owed to workers.

The importance of grassroots organizing is to develop a presence that can lead to a more organized political participation by concentrating people connected through preexisting kin or community in an effort to build critical mass for consistent organizing (Stephen 2007). While some projects begin as income producing activities, community organizations provide members with an opportunity to develop pride and solidarity as well as new skills in public speaking, leadership, and education (Stephen 2007). In terms of union relationships, worker centers and community organizations are mobilizing and organizing agencies and individuals that the labor movement has been unwilling or unable to organize; while on the other side, unions can provide community organizations 
with the expertise and knowledge of labor law, capacity for industry analysis, and financial resources to support organizing drives (Fine 2006). For these reasons, working together, community organizations and unions may help revitalize the country's labor movement, building density and creating new approaches that best fit the nature of the economy within the current phase of neoliberal restructuring (Ness 2005, Fine 2006).

\section{Conclusion}

Today, millions of low-wage immigrant workers make up the backbone of the American economy. From an economic stance, these workers represent a cheap supply of labor that allows business and industry to remain competitive and consumers to benefit from affordable food, clothing, and luxury items. For the immigrant workers, the opportunity to earn dollars and provide their families with a steady source of income often translates into offspring education, improved housing conditions, or investment capital for a small business. Unfortunately, current economic and immigration policies do not return the favor, rendering the heavily undocumented, labor force "illegal" and criminalizing workers under a discourse of national security.

At the crossroads of the country's current models of economic, labor, and immigration policy, businesses are provided with a variety of opportunities to bypass labor laws and exploit immigrant labor. In this sense, unfair business practices thrive amidst decreasing resources for investigation and enforcement of wage and hour violations, breaking the law under the knowledge that they will not get caught. In addition, businesses that knowingly hire undocumented workers can shield themselves from accusations of exploitation by playing on the workers' fears of prosecution and deportation. Finally, by ignoring or failing to attract immigrant workers, unions have contributed to the problem, since in the absence of governmental protection, immigrant 
workers also lack any collective bargaining abilities that would grant them the power to assert their rights.

Widespread practice of wage theft raises many questions about the nature and extent of the problem. For millions of low-wage, immigrant workers in the country, the practice may represent falling behind in economic obligations at their home country as well as poverty and marginality at the host country. In the absence of adept government regulation, inclusive immigration policy, and union consideration, a variety of self-help worker centers and community organizations have emerged as an invaluable resource to claim workers' stolen wages. These organizations have helped to disprove traditional misconceptions about the so-called "unorganizability" of immigrants, garnering support from unions and approaching police departments, city commissions, and business organizations in the pursuit of fair labor standards for immigrant workers. 


\section{MAPPING OUT THE FLORIDA GREEN INDUSTRY}

In this chapter I focus on the industry structure and economic characteristics of Florida's plant nursery industry. Although the analysis is rather economical and technical in nature, it is important to provide the reader with as much background information on the industry in order to better understand some of the interactions, relations, and dependence among industry actors that I analyze in the following chapters. To this end, I explain the national level categories or sectors of the industry and their economic status. I then provide an overview of how the different sectors of Florida's plant nursery industry are categorized and their economic status. Following with a basic description of what is known about the impacts of the industry to the state economy.

In the U.S. the Environmental Horticulture industry, also generally referred to as the Green Industry is composed of various kinds of businesses. In the State of Florida the Green Industry's broad array of businesses include and range from small individuallyowned up to large wholesale nurseries, greenhouse producers, lawn and garden suppliers, nursery and greenhouse equipment manufacturing, wholesale trade, landscape design, installation and maintenance services, lawn and garden stores, and a variety of retail enterprises that sell plants as well as lawn and garden supplies. Analyses and reports on the Green or Environmental Horticulture Industry fold together producers of nursery crops, turf grass sod, and floriculture crops, as well as those other related segments mentioned above. The main focus of this chapter, however, is on the basic data on the nursery crops and greenhouse producers, but because of the interrelatedness of the different sectors of the industry I also offer similar information on other sectors of the Green Industry, such as landscaping and retail.

Nursery crops include finished ornamental plants and trees with woody stems, including deciduous shade trees, deciduous flowering trees, deciduous shrubs and other 
ornamentals, fruit and nut plants intended for outdoor and landscape use, as well as cut and live Christmas trees, and propagation material or lining-out stock (Jerardo 2007). ${ }^{6}$ Although most crops classified under this category of "nursery crops" are grown outdoors and in large containers, some production does take place in greenhouses or shade houses. This second category of crops is often identified in the literature as floriculture or greenhouse crops. Throughout the literature the terms floriculture and greenhouse crops are used interchangeably and in this manuscript I also follow that convention and use floriculture and greenhouse to mean the same sector of growers, but not the same as nursery crops. To make the issue of nomenclature even more confusing is the fact that while most floriculture or greenhouse production takes place in greenhouses there is also production in out-of-doors fields in Florida.

Floriculture or greenhouse crops include foliage plants, potted flowering plants, bedding plants, cut-cultivated greens, and cut flowers. Foliage plants are sold in pots and hanging baskets for indoor and patio use, including larger varieties for offices, hotels, and restaurant interiors. Potted flowering plants are mainly sold in pots for indoor use and some of the largest crops among these include poinsettias, orchids, and chrysanthemums. Bedding and garden plants consist mostly of young flowering plants that are grown in flats, trays, pots, or hanging baskets, usually inside a controlled greenhouse environment, and are largely used for gardens and landscaping. The largest amount of cut flowers are sold in bunches or as bouquets with cut foliage. The most popular cut flowers in the U.S. are roses, carnations, gladioli, and chrysanthemums (Hall, Hodges, and Haydu 2005). For definitions and a view of the extraordinary diversity

${ }^{6}$ Propagative material includes cuttings, liners, plug seedlings, prefinished plants, or tissue cultured plantlets, and unfinished plants sold to other growers for further growing. Please see Appendix A for a list of terms and definitions. 
of products generated by the Florida nursery crops and floriculture sectors please see Appendix A.

\section{U.S. Nursery and Greenhouse Crops}

At the national level, environmental horticulture, and specifically the two sectors of floriculture and nursery crops production have been among the fastest growing segments of the agricultural economy over the past two decades, showing periods of growth and expansion even during periods of recession. According to industry experts, the slowing growth of recent years can be attributed to a maturing of the industry, that is, the number of producers has increased to the point where demand is filled or saturated (Hall, Hodges and Haydu 2005).

The number of nursery producers across the entire U.S., as estimated by the United States Department of Agriculture (USDA) Census of Agriculture for 2007, was 22,407. The states with the largest number of producers were Florida, Oregon, North Carolina, and California (Nursery Crops 2006 Summary), although it should be noted that Florida has numerous small producers while California's smaller number of producers tend to be larger. Nationally, the total sales of nursery crops in 2006 was estimated at $\$ 17$ billion, where the leading three states as measured by value of sales were California with 24 percent, Oregon with 18 percent and Florida with 17 percent of total nursery crops sales (Jerardo 2007). The number of hired workers in 2006 was 112,672 of which 54 percent were paid for 150 days or more. The average number of workers per operation who were paid for 150 days or more was 16 (Jerardo 2007) 7.

${ }^{7}$ The U.S. Department of Agriculture's Economic Research Service publishes different reports at different time intervals. The main publications for nursery and greenhouse/floriculture production are Floriculture Crops, which is published annually and which Includes data on quantity sold, percent of sales at wholesale, wholesale price and value of sales at wholesale for 15 selected States and growers having $\$ 100,000$ or more in sales, and; Nursery Crops, which was published every 3 years until 2007 and Included data for 17 selected States, and growers having $\$ 100,000$ or more in sales. In this chapter I have included the numbers from the 2006 (published in 2007) 
In terms of floriculture or greenhouse crops, the national 2011 wholesale industry value was $\$ 4$ billion. California was the leading state with crops valued at $\$ 1.1$ billion and Florida was the next largest producer at $\$ 835$ million in wholesale value. The next three top producing states were Michigan, Texas, and North Carolina, which account for 65 percent of the 15-State total value (Floriculture Crops 2011 Summary). In 2011 the number of floriculture crop producers at the national level, as estimated by the USDA Census of Agriculture for 2007 was 5,700. The average peak number of hired workers employed on operations in the 15 leading states in 2006 was approximately 18 with a total of 4,382 operations reporting hiring workers during 2011, and an estimated 76 percent of the operations using some hired labor during 2006 (Floriculture Crops 2011 Summary).

\section{Florida. Nursery and Greenhouse Crops}

Nursery plants are one of the largest and most important agricultural commodities in the state of Florida, along with fruits, vegetables and forest products (Hodges and Mulkey 2006). According to the Census of Agriculture for 2007, the state of Florida had over 4,700 commercial nursery and greenhouse farms. Nursery operations reported having 45,000 acres in the open and about 68 million Sq. feet under glass or other protection, while floriculture or greenhouses operations reported 9,000 acres in the open and about 256 million Sq. feet under glass or other protection (USDA-NASS, Census of Agriculture, 2007).

Floriculture and nursery crops represented a substantial rate of growth between the last years of the 1970 s to the mid 1980s, when the rate of growth began to stabilize

Nursery Crops report and the most recent 2011 (published in 2012) Floriculture Crops report. Some of the information for this chapter also comes from the Census of Agriculture, which is conducted every five years and provides a detailed picture of U.S. farms and ranches and the people who operate them. The last census conducted was in 2007 , thus, whenever there are actualized reports or data sets I will use newer data, but new full reports will not be made available until after the 2012 census of agriculture is completed. 
(Hodges and Haydu 1992); the rate of growth increased again between the late 1990s and 2005. According to official United States Department of Agriculture (USDA) data, plant nursery sales in 2010 were estimated at about 1.7 billion in total sales or about $22 \%$ of the total agricultural production of the state. Figure 1 shows the grower cash receipts for floriculture and nursery crops in the state of Florida between 2000 and 2010 (NASS 2011).

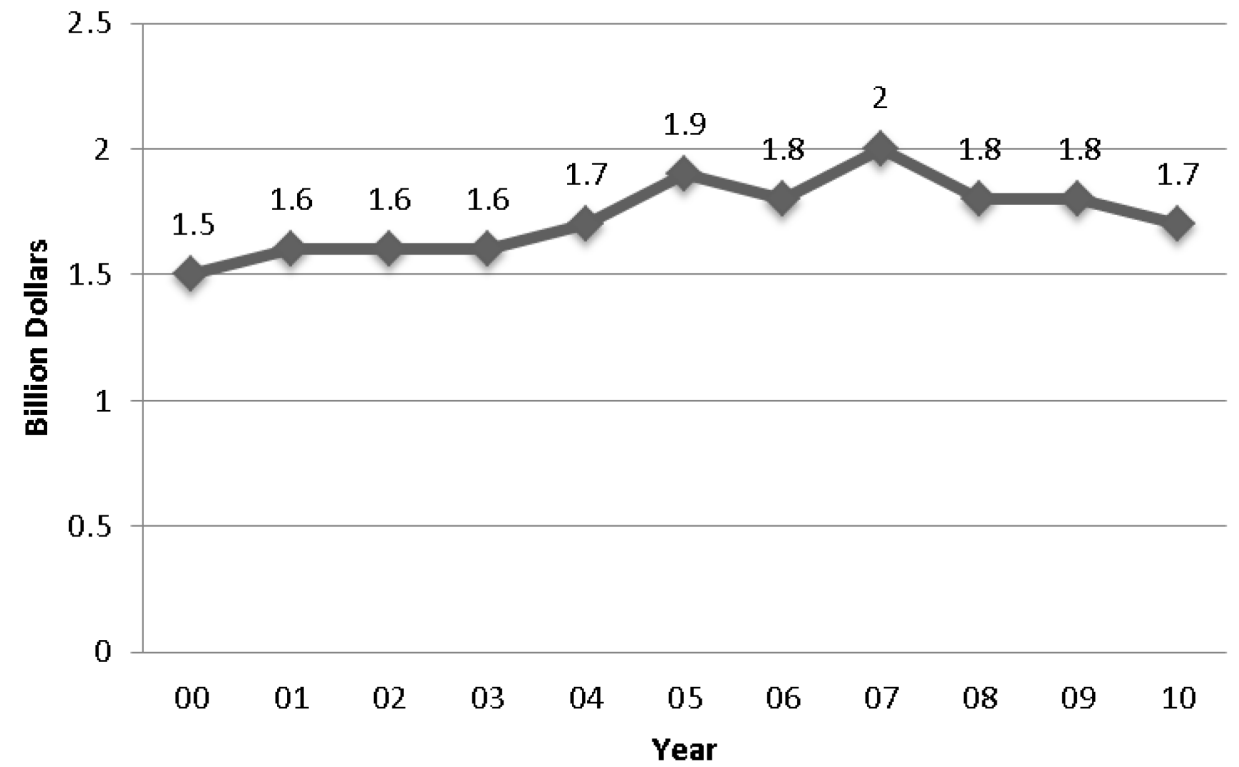

Figure 1. Florida Greenhouse and Nursery Crops: Value of sales 2000 to 2010 (USDA-NASS 2011)

Miami-Dade is the Florida County with the largest number of floriculture and nursery crops producers and the leader in value of yearly sales with over 800 producers reporting \$286 million from floricultural production and close to \$195 million from nursery crops production. Orange, Palm Beach, and Lake Counties are also among the top producers of nursery crops and floriculture (USDA-NASS Census of Agriculture, 2007). Tables 1 and 2 show the characteristics of the top five producing counties in Florida according to value of sales for the year 2007. 
Table 1. Characteristics of Florida's Top Five Nursery Crops Producing Counties in 2007

\begin{tabular}{ccccc}
\hline County & $\begin{array}{c}\text { No. of } \\
\text { Farms }\end{array}$ & $\begin{array}{c}\text { Sq. ft. under } \\
\text { glass or other } \\
\text { protection }\end{array}$ & $\begin{array}{c}\text { Acres in } \\
\text { the open }\end{array}$ & $\begin{array}{c}\text { Value of sales } \\
\text { Dollars }\end{array}$ \\
\hline Miami-Dade & 587 & $43,182,682$ & 10,279 & $194,627,381$ \\
\hline Palm Beach & 333 & $2,160,146$ & 3,265 & $77,776,033$ \\
\hline Lake & 126 & $1,410,375$ & 2,384 & $68,964,160$ \\
\hline Hillsborough & 211 & $2,840,968$ & 2,520 & $57,497,269$ \\
\hline Orange & 93 & $4,479,114$ & 524 & $29,026,419$ \\
\hline
\end{tabular}

Source: U.S. Department of Agriculture - National Agricultural Statistics Service (USDA-NASS). Census of Agriculture, 2007. Florida State and County Data, vol. 1, Geographic Area Series, Part 51. Washington, D.C., February 2009.

Table 2. Characteristics of Florida's Top Five Floriculture Producing Counties in 2007

\begin{tabular}{ccccc}
\hline County & $\begin{array}{c}\text { No. of } \\
\text { Farms }\end{array}$ & $\begin{array}{c}\text { Sq. ft. under } \\
\text { glass or other } \\
\text { protection }\end{array}$ & $\begin{array}{c}\text { Acres in } \\
\text { the open }\end{array}$ & $\begin{array}{c}\text { Value of sales } \\
\text { Dollars }\end{array}$ \\
\hline Miami-Dade & 300 & $64,527,816$ & 1,967 & $286,097,476$ \\
\hline Orange & 184 & $22,568,600$ & 217 & $174,174,893$ \\
\hline Volusia & 234 & $90,514,590$ & 2,851 & $84,359,288$ \\
\hline Palm Beach & 96 & $12,179,067$ & 891 & $75,577,892$ \\
\hline Lake & 122 & $14,203,561$ & 390 & $62,460,084$ \\
\hline
\end{tabular}

Source: U.S. Department of Agriculture - National Agricultural Statistics Service (USDA-NASS). Census of Agriculture, 2007. Florida State and County Data, vol. 1, Geographic Area Series, Part 51. Washington, D.C., February 2009.

\section{Impacts and Characteristics of the Florida Nursery industry Labor Force}

According to a 2010 report by the Institute of Food and Agricultural Sciences (IFAS) at the University of Florida (UF), the estimated total employment impacts for the nursery/greenhouse industry in Florida accounted for approximately 98,000 jobs $^{8}$. County level employment impacts were greatest in Miami-Dade with about 25,000 jobs; Orange with 13,000; Volusia with approximately 8,000; Hillsborough with over 6,500; and Palm beach with approximately 5,800 (Hodges, Stevens, Rahmani, and Khachatryan 2010).

\footnotetext{
${ }^{8}$ The numbers of the report differ largely from the numbers reported by the Florida Department of Economic Opportunity, which monitors and reports the state of employment in the State of Florida, because the IFAS report relies on a series weighs and statistical calculations to account for the impact of those numbers not reported to the state's agencies.
} 
A review of the 2012 available data on wages from the State of Florida Department of Economic Opportunity estimates the wages of Farmworkers and Laborers of Crop, Nursery, and Greenhouse operations ${ }^{9}$ at a median hourly wage of of $\$ 8.40$ with entry level wages of $\$ 8.14$ and wages of $\$ 9.83$ for expert workers. In terms of benefits, no recent information is available for this particular group. However, a 2007 study on the working conditions of nursery fieldworkers in Miami-Dade County revealed a widespread lack of health benefits, no overtime wages, as well as a variety of wage, safety, and varied harassment violations (Angee and Hernandez 2007). The study found that many workers in the Miami-Dade plant nursery industry often receive hourly wages under the minimum wage or a daily payment regardless of the number of hours that they work, which may be over eight hours per day.

The study also looked into workers' knowledge of and access to information regarding laws and rights at their workplaces, revealing that a great number of the research participants had no clear idea of what the state's minimum hourly wage was. Many nursery workers complained that there were no posters or other information telling them of basic work standards or regulations at their job sites and that they would not be able to extract such information from their employers. The workers also report that reliable information is not available from co-workers. The Angee, Hernandez study (2007) also highlights the accentuated vulnerability to abuses because of the workers' lack of knowledge of organizations, agencies, or institutions that can help them in situations of harassment and/or wage theft with the situation often aggravated by the worker's lack of legal immigration status. I address the issues faced by Florida Nursery

\footnotetext{
${ }^{9}$ This category includes farm labor of nursery/greenhouse crops as well as those in other farming and cropping industries.
} 
workers in detail in chapter six, including an analysis of the migration and incorporation patterns of low wage immigrants to the state and to its plant nursery industry.

The closest approximation of the characteristics of the industry's labor force is found through the National Agricultural Workers Survey's (NAWS) public data set, which includes all agricultural workers of the Southeastern U.S. The survey estimates the regional foreign-born agricultural population to be 63 percent with an average age of 35 and an estimated eight years residing in the U.S. The female labor force is estimated at 21 percent and the undocumented population is estimated at 49 percent, with only about one percent having a (non-specified) type of work permit or authorization. Unfortunately, the NAWS data is overly broad to determine more than an approximation of nursery crop and floriculture workers, since it includes all types of agricultural workers within a conglomeration of six Southeastern states and not just nursery crops and greenhouse employees in the state of Florida. Unfortunately, there is no database or survey specifically detailing the demographic characteristics of the Florida nursery crop and floriculture workforce. However, I did extract anecdotal evidence from industry professionals and local organizers involved in the industry to elucidate some of the numbers, but these are approximations at best. Because such numbers do not originate from systematic data gathering I make no generalizations, but rather understand that they are best guesses by well-informed observers and stakeholders. For instance, Jonathan Fried of WeCount! estimates that about 90 percent of the Miami-Dade County nursery crops and greenhouse labor force is Hispanic (mostly Mexican and Guatemalan) with about $40 \%$ female and $60 \%$ male. The remaining $10 \%$ of the labor force, he believes is divided among African Americans, Haitians and other ethnicities. Researcher Tim Steigenga of Florida Atlantic University estimates the demographic distribution of Palm Beach county greenhouse and nursery crops workers at 75 percent Hispanic, with 
a ratio of 60 - 40 Guatemalan - Mexican workers and the other 25 percent being African American, Haitian, and Anglo.

The plant nursery industry relies heavily on labor intensive work from an immigrant work force. In addition, it became clear to me through employer and industry professional interviews as well as through the documents and opinions of industry organizations that a great deal of the industry's workers are undocumented or not legally permitted to work in the U.S. The legal status of industry workers poses clear difficulties to both workers and employers. As the Florida Nursery Growers and Landscapers Association (FNGLA) president explained to me, "growers don't want to have the specter of the federal government officials coming in and raiding their business operations, penalizing them with fines, or taking in workers in whom you've invested time and resources so that they're trained."

To exacerbate the issue, the use of guest worker visas is not a common practice in the Florida nursery crops and greenhouse sectors of the industry. The FNGLA president described the situation as one where employers avoid the use of $\mathrm{H} 2 \mathrm{~A}$ visas because it is expensive and contains very stringent impositions on workers' living arrangements. The opinions of this industry professional reflect those of my employer and employee interviews from this and previous studies in Miami-Dade County, where I found the use of the $\mathrm{H} 2 \mathrm{~A}$ visa is virtually unknown in the nursery crops and floriculture sectors with the majority of undocumented workers in these sectors having crossed illegally through the U.S. - Mexico border and settling in Florida through pre-established social networks (Angee and Hernandez 2007). In chapters five and six, I provide a in-depth analysis of the attitudes and behaviors of plant nursery industry professionals and operators regarding the recruitment, regulation, and employment of the immigrant labor force. 


\section{Size of Florida Firms}

Plant nursery production in Florida is mostly handled by many small to medium sized producers. In terms of size of land and firms for instance, the UF/IFAS report (Hodges et al. 2010) estimates about 55 percent of Florida growers with greenhouses or shade houses reported having small production areas of less than 10,000 sq. $\mathrm{ft}$., while less than 1 percent reported having large areas of more than 1 million square feet. More than 38 percent of operations reporting container or open field production have farms sized 10 acres or less. These percentages demonstrate the overrepresentation of small firms within the nursery crops and floriculture sectors in Florida and the very small number of large producers. Figure 2 shows the distribution of greenhouse or shade-house production by square footage capacity and where the imbalance in numbers of small producers relative to large ones is evident. Figure 3 shows the distribution of the container and field nursery areas by size reported by producers ${ }^{10}$.

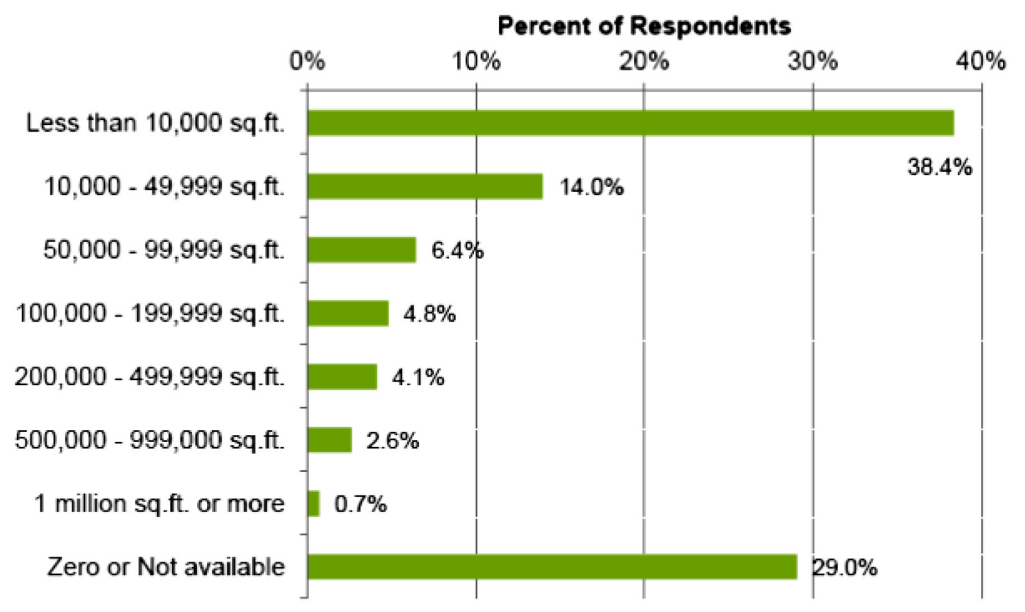

Figure 2. Greenhouse use reported by respondents of the Economic Impacts of the Florida Environmental and Horticulture Industry Study (Hodges et al. 2010).

\footnotetext{
${ }^{10}$ Survey respondents in the IFAS nursery industry study were asked to report their production areas separately for greenhouse/shadehouse facilities (as shown in Figure 2) and container or field growing areas (shown in Figure 3). The large number of respondents who reported "none" for container/field areas were strictly greenhouse/shadehouse operations.
} 


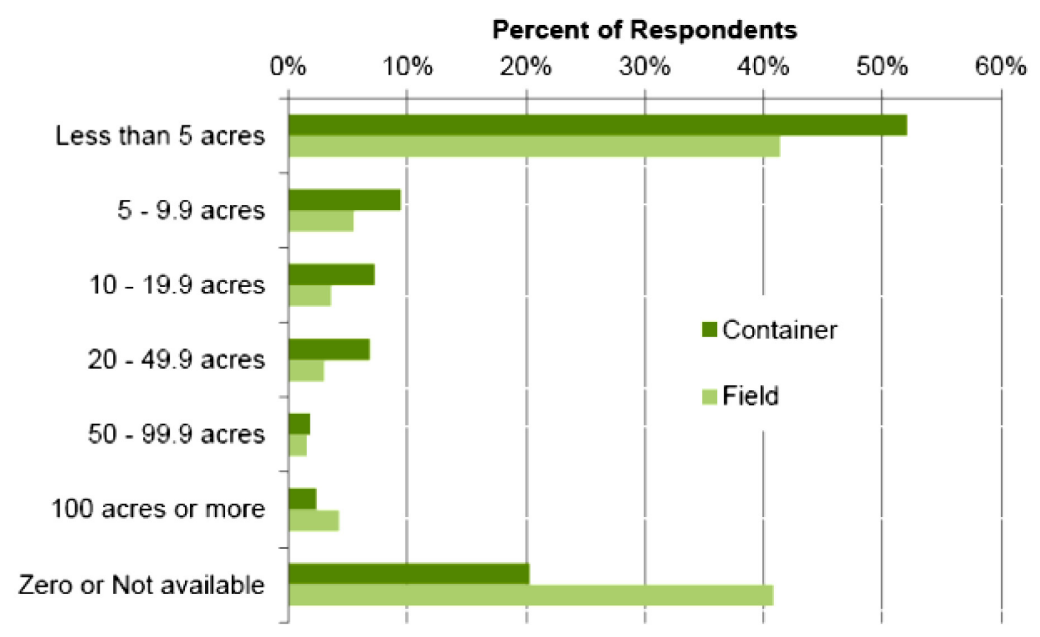

Figure 3. Container and field nursery area use reported by respondents of the Economic Impacts of the Florida Environmental and Horticulture Industry Study (Hodges et al. 2010).

\section{Sales Trends for Florida Floriculture and Nursery Crops}

The largest selling crop for nursery producers in Florida are tropical foliage plants with 2010 sales of approximately $\$ 1.8$ billion or about 35 percent share of total horticultural sales, followed by potted flowering or bedding plants at a combined $\$ 916$ or 22 percent of total sales. Palms and Florida native plants are also major specialty crops in the Florida industry (Hodges et al. 2010). Sales of most nursery crops are more largely directed toward other states, while about 44 percent of production is sold to costumers in local or regional markets (see figure 4). ${ }^{11}$

Measured by sales volume in 2010 the most important customer within the commodity chain of nursery products was to home improvement stores with about 37 percent of sales. Sales to landscaping contractors accounted for about 14 percent of sales, while mass merchandise stores account for 12 percent of sales, and rewholesalers or brokers accounted for 11 percent of sales, while independent retail garden centers accounted for about 9 percent of sales (see figure 5).

\footnotetext{
${ }^{11}$ Sales of industry firms are organized by market region and categories include international, national, state, and local areas. Local areas are defined as the city or county in which the business is located, or within a 50 mile radius.
} 


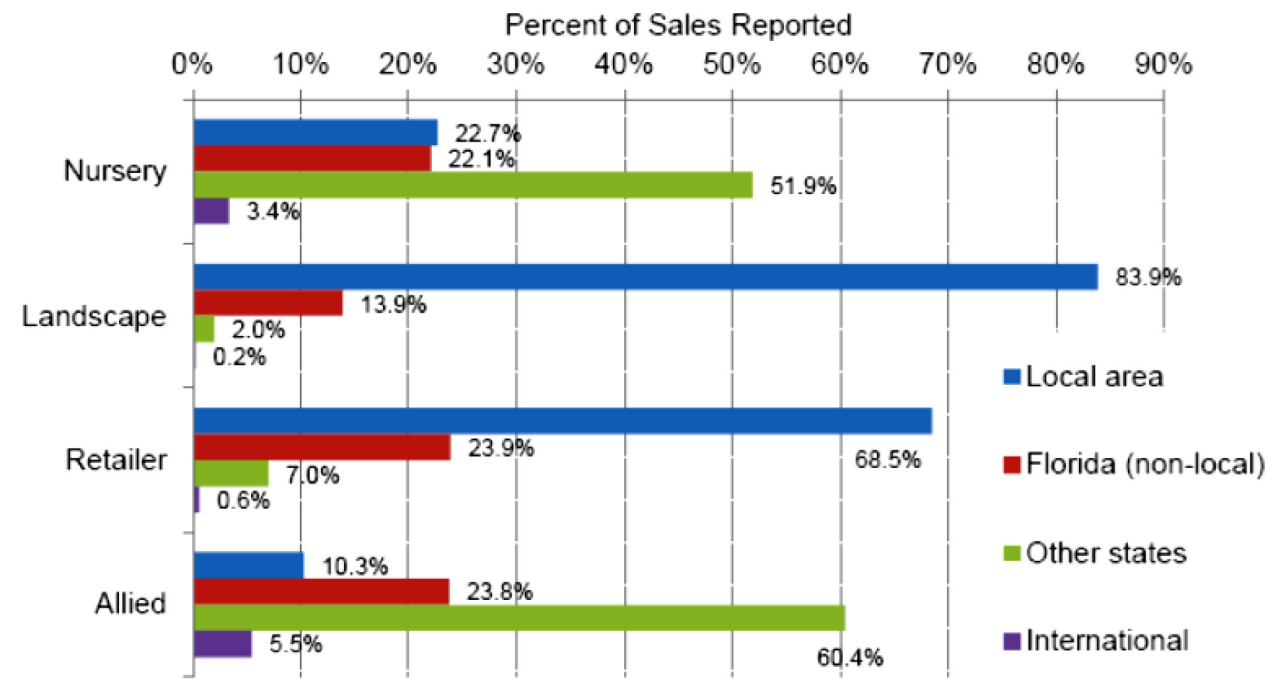

Figure 4. Distribution of horticultural industry sales by market region reported by respondents of Economic Impacts of the Florida Environmental and Horticulture Industry Study (Hodges et al. 2010).

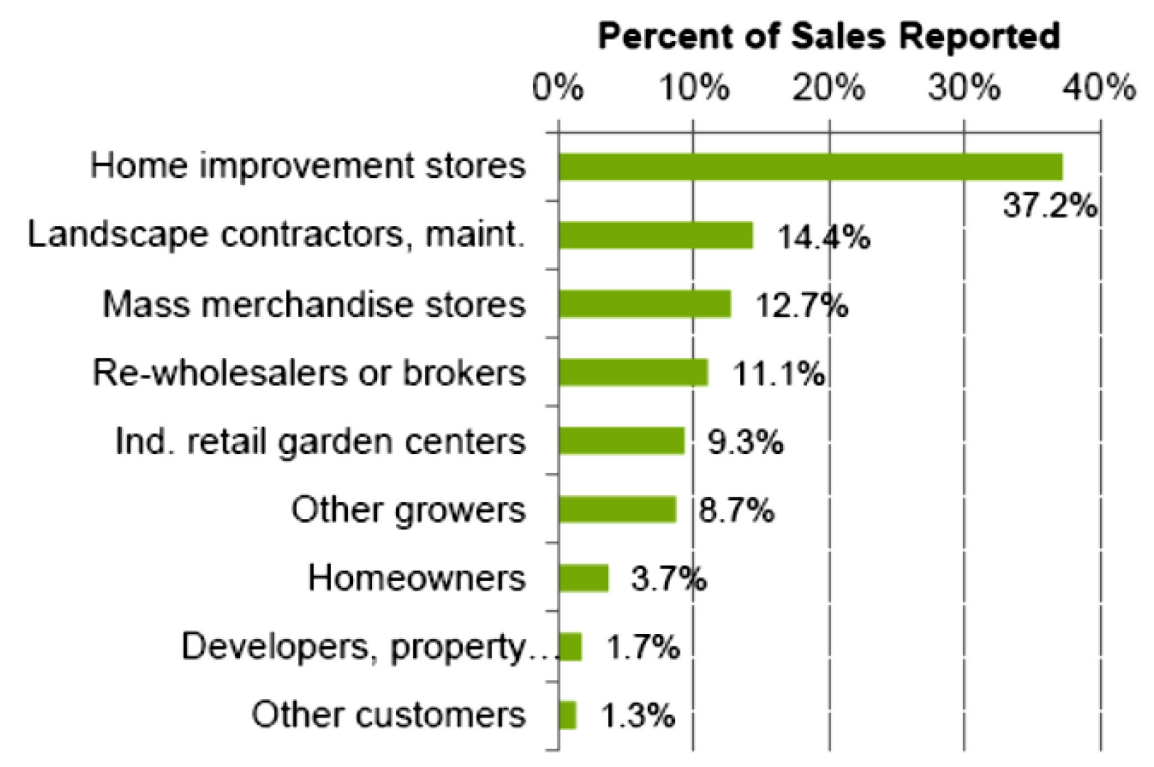

Figure 5. Distribution of nursery and greenhouse product sales by type of customer reported by respondents of the Economic Impacts of the Florida Environmental and Horticulture Industry Study (Hodges et al. 2010).

Plants often go through several firms within the industry before arriving at their final destination. This is because some businesses within the industry only produce liners or starters, or small potted trees, which are sold to other firms to grow to maturity. In 
addition, many businesses that sell to large buyers, such as big box stores, often buy plants from other nurseries to complete large orders. This practice is often referred to as brokering, where nurseries often buy large quantities from other local producers in order to fill large orders.

A closer look at the nature of sales and marketing strategies of nursery crops and greenhouse growers highlights some of the issues associated with the un-concentrated nature of the industry. Such un-concentration results in part because many nursery crops and greenhouse firms have wholesale, landscaping and/or brokering operations in addition to the plant production aspect of their business. My interviews with industry operators demonstrate that plants often change firms several times before reaching a final destination. As one employer explained,

If we have to fill a large order [of plants], we often have to call other nurseries to complete what the buyer is searching for. We do not want to lose the order so we buy from others in order to facilitate the client's shopping experience... This is often done to supply another broker who is selling to one of his clients, so by the time the plants get to the retailer or landscaper, some of them will have been sold and resold two or three times.

Wholesale sales of nursery products are often handled by salespersons with established relationships to buyers in specific markets. Marketing channels often include trade shows, advertising in trade publications, and catalog sales. Close planning with large buyers is often required to secure long-term markets and to ensure that the buyer's desired product mix is produced and available. However, demand for different products varies substantially from year to year as items that are in demand change from year to year (Hall, Hodges and Haydu, 2005). These trends were also articulated by several of my employer informants, who also report doing the sales themselves as opposed to having salespersons in their operations. 
As the analysis reveals, the nursery crops and floriculture sectors of the Green Industry in the state of Florida is composed of a significant conglomeration of small and medium sized independent firms; and while some firms have grown to achieve large operations in terms of land and value, these tend to remain independently owned. In this sense, I found no solid evidence that publicly traded firms are parent companies to smaller nurseries or groups of nurseries in the state as is the case with other forms of agriculture of fruits and vegetables.

My analysis demonstrates that the structure of the industry is complex, inter-reliant and highly un-consolidated. A relatively high proportion of small and medium sized firms account for a significant share of industry production and value, while a highly diverse array of commodities produced and multiple market channels exacerbate the unconsolidated nature of the industry; often preventing a variety of organizational efforts such as cooperatives and collective marketing strategies (Hodges and Haydu 1992). Despite this highly un-concentrated and fragmented industry structure, entrepreneurs of the plant nursery and landscape industry are well organized and represented in the state and national political process through professional business associations such as the Florida Nursery Growers and Landscape Association (FNGLA), the American Nursery and Landscape Association (ANLA), and the Florida Farm Bureau.

The highly un-consolidated organizational structure extends to other sectors of the Green Industry as well. With landscape services and home garden retail providing important sources of jobs, income, taxes and added value to the production and sales of horticultural products in the state. In the following section I look at these other sectors of the "green industry" to clarify the extent and depth of the exchange of horticultural or nursery production. This step provides a preliminary look necessary for a power analysis of the industry. In the next section I provide an overview of the total industry structure. I 
believe that an understanding of this structure is necessary to an understanding of the commodity chain and how some producers play multiple roles in that chain.

\section{Industry Structure and the Commodity Chain in Florida}

The environmental horticulture or "Green" industry consists of a variety of businesses involved in production, distribution, and sales and services associated with ornamental plants, landscape and garden supplies and equipment. The industry is comprised of wholesale nurseries, field and container and greenhouse production, and sod growers, landscapers, landscape architects and landscaping, maintenance firms, retail garden centers, home centers and mass merchandisers with lawn and garden departments, as well as marketing intermediaries such as brokers, horticultural distribution centers, and re-wholesalers (Hall, Hodges and Haydu 2005). Total Florida industry sales in 2010 were estimated at $\$ 16$ Billion, including $\$ 8.12^{12}$ Billion by nursery and greenhouse operations, $\$ 6.24$ Billion by landscape service firms, and $\$ 1.6$ Billionn by horticultural retailers, while the impact on indirect business taxes paid to state and local governments was estimated at $\$ 668$ Million (Hodges et al. 2010). ${ }^{13}$

I start the industry description with the "Green Industry" box labeled "Nursery \& Greenhouse Production" located in the top left of Figure 6, which includes firms engaged in greenhouse and nursery crops production. I then move on to describe other boxes or sectors of the Green Industry that represent the interdependent relationship of these

\footnotetext{
${ }^{12}$ This number contrast greatly with the numbers available from the USDA and its related research services detailed in footnote 2 above. This is due to the methodology used in the UF/IFAS economic industry report which uses a complex system of economic multipliers based on a representative sample of surveyed nursery firms in the State of Florida.

${ }^{13}$ A major source of research and information on the Green Industry is the Institute of Food and Agricultural Science (IFAS) at the University of Florida (UF). Consequently this section relies heavily on IFAS publications to provide the background for the industry structure and commodity chain analysis.
} 
sectors to the growers of greenhouse and nursery crop growers. First in this list are the boxes labeled "Landscaping Services Sector" and the retail part of the box labeled "Wholesale and Retail Trade." From there I move to the box labeled "Input \& Service Suppliers" in the lower center of Figure 6. I conclude this section with a consideration of sectors that I believe should have been included in the structure and linkages schematic, viz, "Transportation and Distribution," "End-Users," "Research and Extension Services," and "Professional Organizations."

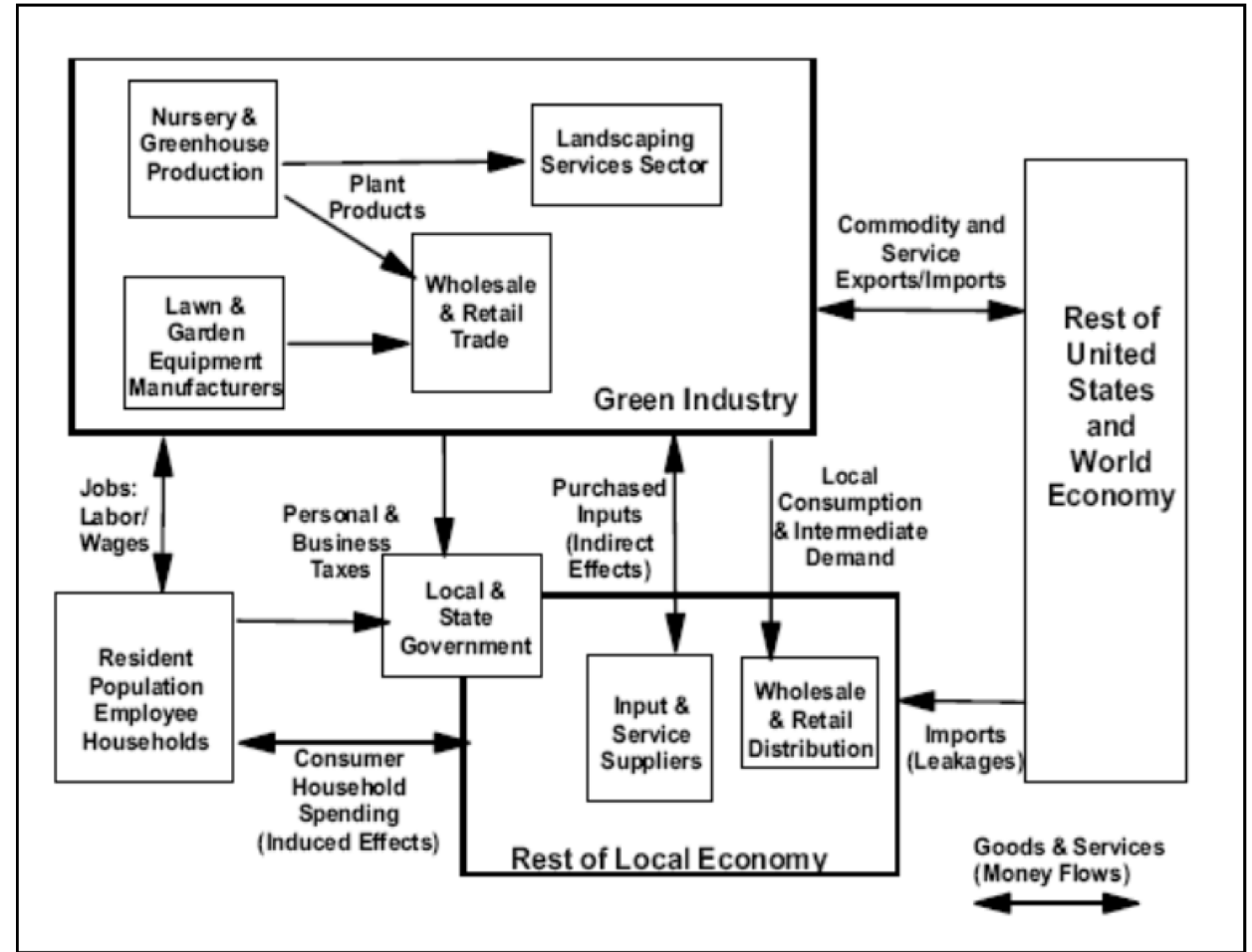

Figure 6. Market Structure and Economic Linkages of the Green Industry (Hall et al. 2005)

The sectors of the "Green Industry" are highly related, yet un-concentrated and diverse, particularly because firms may be producers of nursery and floriculture crops and also offer retail, wholesale, and/or landscaping services. As an interview with a Central Florida Farm Credit professional revealed, "many nurseries perform landscape services as well, while many garden centers have small crop production facilities 
integrated to their operation. ${ }^{14}$ In addition, a complex system of brokering and rewholesaling further complicates the task of classifying firms and their roles within the industry. Some companies specialize in consolidating products from numerous producers for large shipments to big box stores or to garden centers inside and outside of the state, while sometimes this same function is performed by growers themselves. Brokers and re-wholesalers buy different quantities and plant varieties from a number of nursery firms throughout the state and re-sell them as a consolidated package to large buyers. ${ }^{15}$ One consequence of this diversity within individual firms is that any individual grower may not be dependent only on crop production for his income.

\section{Nursery and Greenhouse production}

Location sites for nursery crops production are largely determined by factors such as soil, climate, availability of water, accessibility and distance to markets, and cost of land, since plant species have a hardiness zone determined by the northern geographic latitude for in-ground growth. As a result, trees and shrubs start out as "liners" (rooted trees and plants in undeveloped states and arranged in pots or trays). These are usually protected from severe weather by a shade or temporary cover and then transplanted into larger containers or the field for additional growth. Sales occur at any stage of development depending on the plants' commercial purpose (Hall, Hodges, and Haydu 2005). The diversity of crops produced in Florida is large and adds to the complexity of the commodity chain.

Sales of most nursery crops in Florida are more local or regional than floriculture crops, which are less delicate and costly to ship to farther markets. Market outlets for floriculture crops often include florists, garden centers, mass merchandisers,

\footnotetext{
${ }^{14}$ Interview with Regina Thomas, farm Credit of Central Florida's Senior Vice President and Chief Business Development Officer. December 2009

${ }^{15}$ Interview with nursery owner in Miami Dade County. October 2009.
} 
supermarkets, chain stores, discount stores, home improvement centers, hardware stores, landscape contractors, and re-wholesalers. In addition, other retail outlets may include farmers markets, flea markets, and street vendors. Homeowners are the typical consumers of trees, shrubs, and woody ornamental plants; however, other end users often include construction contractors and developers, golf courses, resorts, parks, malls, and government agencies in charge of parks, street and highway vegetation, and forests (Hall, Hodges, and Haydu 2005).

Most firms surveyed by the UF/IFAS economic impact study were mature businesses, with firms reporting having been in business for an average of 18 years (Hodges et al. 2010). In 2010, the majority of sales in the nursery/greenhouse sector was to home improvement stores and representing about 37 percent of total sales. This number was followed by sales to landscapers and interiorscapers at about 14 percent, while sales to mass merchandise stores accounted for 13 percent. Interestingly, the combined percentage of sales to other growers and to re-wholesalers was about 20 percent, again indicating the extent through which plants circulate within industry firms before reaching retailers and final users (Hodges et al. 2010).

Plant brokerage (i.e., buying and reselling finished plants) has been estimated to include 47 percent of growers, with the activity representing about 20 percent of total sales in 2010. This market still represents large sales volumes for a relatively small number of sellers, which indicates very concentrated market channels that are held mostly by large producers. This phenomenon was supported by the president of the Miami-Dade County FNGLA in an interview. This industry professional explained that sales of nursery products to large retail chains are very specific to large firms or broker operations which consolidate products for companies such as Home Depot, Lowes, or Wal-Mart. Production contracted with a buyer in advance is also a common activity 
reported by 45 percent of firms, but representing less than 1 percent of sales. Sales to repeat customers represent about 74 percent of total sales in 2005 (Hodges and Haydu 2006)

\section{Landscaping Services}

Landscaping services are another important segment of Florida's Green Industry and a major consumer of floriculture and nursery crops products. Nationally, the landscape services sector has grown rapidly over the last 30 years due to expansion in residential housing and commercial development, greater investment in re-landscaping of existing properties, and increasing use of professional lawn and garden maintenance services (Hall et al 2005). Industry growth has been particularly strong in Florida, where sales grew from an estimated $\$ 3.2$ billion in 1997 to $\$ 5.3$ billion in 2005 (inflation-adjusted), thus representing an average annual growth of 6.5 percent. (Hodges and Haydu 2006).

In 2005, the most important customers for landscape firms were governments at 29 percent; however, by 2010 this number had decreased drastically to about five percent. Although there is no analysis of why this number decreased so drastically in about five years, it could be related to fiscal austerity measures adopted by state and local governments as a result of the economic resection of recent years. Government contracts often include highway beautification projects, for which the Florida Department of Transportation allocates an important portion of its yearly budget, ${ }^{16}$ or remodeling projects of public facilities such as museums, zoos, and other public sites. In 2010, thus, the largest customer for landscape firms were homeowners, representing 36 percent of sales, followed by apartments and condominiums at 22 percent and builders and developers at 16 percent of sales (Hodges et al. 2010).

\footnotetext{
${ }^{16}$ Florida Department of Transportation, Highway Beautification Program. http://www.dot.state.fl.us/emo/beauty/beauty.shtm.
} 
An estimated 44 percent of Florida landscaping firms report maintenance as their main activity, followed by 23 percent doing landscape installation as their main activity, and 12 percent from the sale of live plants 9Hodges et al. 2010). The Hodges et al. (2010) report, estimates the total number of state landscape workers In 2010 at 111,000, with an estimated 78 percent of full time workers in surveyed firms. In 2005, about 26 percent of firms had 10 or more employees, and 2 percent had over 100. Laborers represent over 51 percent of all employees, followed by equipment operators at 10 percent, foreman/supervisors at 8 percent, and horticultural/irrigation technicians at 7 percent (Hodges and Haydu 2006).

Landscape work is labor-intensive, and employee compensation and benefits represent a significant cost for business owners. Some of the problematic issues faced by landscape workers include a lack of private health insurance, decreasing worker protection standards regarding safety equipment and pesticide handling; while for employers it is becoming increasingly difficult to find qualified employees. Anecdotal accounts and reports indicate that a large share of employees in the landscaping sector is undocumented, similar to what is reported for greenhouse and nursery crops workers. In some firms that produce crops and run landscaping businesses, the same workers may work in both activities. According to official data from the Florida Department of Economic Opportunity, in 2011, there were nearly 66,000 jobs in specific landscape service occupations, with a median hourly wage of $\$ 10.45$ and ranging from $\$ 8.24$ to over $\$ 12.53$. However, I am skeptical about the accuracy of these figures, which are reported by employers and which exclude a variety of individual contractors and self employed individuals that are not required to report employment and payroll to the government. 


\section{$\underline{\text { Retail Sales }}$}

In terms of sales the second largest segment of the Florida Green Industry is retail sales. In 2010, this segment accounted for 38 percent of total sale generated by the horticultural industry in the State of Florida. Total sales for 2010 were estimated at over $\$ 1.4$ billion sales and included the sale of plants, lawn garden supplies such as fertilizers and chemicals, horticultural hard goods such as tools and equipment, and miscellaneous other horticultural goods. For horticultural retailers the dominant market or end user was homeowners, representing 51 percent of total sales, followed by commercial establishments at 19 Percent, and apartments and condominiums at 10 Percent (Hodges et al. 2010).

Garden centers are establishments primarily engaged in selling trees, shrubs, other plants, seeds, bulbs, mulches, soil conditioners, fertilizers, pesticides, garden tools, and other garden supplies to the general public. For the most part, these establishments sell products purchased from producers, but may sell some plants they grow themselves. The demand for floral crops is often seasonal, with Poinsettia plants sold mostly from Thanksgiving to Christmas and cut flowers and foliage plants, popular throughout the year as indoor home and workplace decorations (Hall et al 2005).

At the national level there has been considerable consolidation among large growers in recent years, a condition occurring largely in response to consolidation occurring at the retail level. The rise of large, nationwide plant retailers like home centers and mass merchandisers has created a marketing opportunity for growers who can supply the volume these customers require. Some greenhouse and nursery crop producers have "expanded" their operations through acquisitions during the past decade, mainly to service these big customers (Hall et al). In Florida, where there is slight evidence of consolidation, my interviews with nursery operators and owners, revealed a common 
complaint that large retail stores make the rules of the trade and impose prices for products, reducing the profitability for the nursery operations.

In 2010 the retail segment in Florida accounted for an estimated employment of about 28,000 (Hodges et al. 2010). Reporting specific information about wages and benefits for this sector presents difficulties that require more research. Stores like WalMart, Home Depot, or Lowes do not report specific working wages and benefits for workers in their garden operations. In addition, although some of the big box retail companies report sales of garden centers, it is extremely difficult to know exactly how much of their plant merchandise is coming from Florida producers. A look at Home Depot's yearly sales reports, for example, does not report specific sales of garden centers. ${ }^{17}$ According to Professor Alan W. Hodges from the University of Florida's IFAS,

The largest retailers of nursery and garden products are the home improvement chain stores, such as Home Depot and Lowes, along with the national full line retailers like Wal Mart, K Mart, and Target. Although these companies do not release sales data for specific merchandise lines, I happen to know that the garden department represents about $25 \%$ of total sales for Home Depot. It is probably a lower percentage for the other large retailers.

It has by now become clear to many, that the growth of big box retail stores has been a double-edged sword for producers. During my interviews, owners often complained about the "bullying power" of these retailers. As one owner told us, "it is the big box stores that set the price of a lot our products; they tell us how much they want and how much they are willing to pay for it." The current president of the state FNGLA acknowledges this paradox by explaining how "the big box stores have also created new opportunities and markets for nurseries to sell their products." He also acknowledges that dealing with the box stores may be difficult, especially for operations that are set up to sell a large part of their inventory directly to stores or through re-wholesalers.

\footnotetext{
${ }^{17}$ Supermarkets and large "big box" stores are not included in this list because they are not exclusively classified in financial documents and other literature as retail garden centers according to the North American Industry Classification System (NAICS).
} 
$\underline{\text { Input and Service Suppliers }}$

Input supply firms are businesses that provide various inputs for nursery crops and floriculture production, landscape services, and retail sales. Such inputs include agrichemicals, fertilizers, containers, packaging, farm machinery, tools and equipment, and propagative materials such as cuttings, liners, plug seedlings, pre-finished plants, or tissue cultured plantlets, and unfinished plants sold to other growers for further growing. These propagative materials are often produced by nurseries, which explains the large percentage of nursery sales to other nursery operations.

A review of publications containing specific information about suppliers of raw materials for nursery production yields very few reports. The U/IFAS 2006 study estimates the impacts that the nursery crops and greenhouse sectors have on the purchases of supplies for production from allied vendors. The study estimates the total inputs purchased (excluding labor) at $\$ 821$ million. The largest expense item was for plants and seeds (\$292 million), which is most often purchased from other nursery growers. In other words, over one-third of the input of goods into the nursery crops and floriculture sectors of the Green Industry in Florida as measured by purchases comes from the sale of plants and seeds mostly purchased from other growers. Other expenses included \$147 million in growing containers, \$101 million in growing media, \$82 million in packaging materials, $\$ 81$ million in fertilizer/lime, and $\$ 65$ million in chemicals (pesticides, growth regulators, etc.) (Hodges and Haydu 2006).

My interviews with greenhouse and nursery crops operators (managers/owners) revealed that most of the suppliers of raw materials and machinery are local firms. However, some of the suppliers of containers, fertilizers and other chemicals are national and multinational companies. 
Table 3. Purchases of Supplies by the Nursery and Greenhouse Sector in Florida, 2005

\begin{tabular}{lcc}
\hline \multicolumn{1}{c}{ Expense Item } & $\begin{array}{c}\text { Cost as } \\
\text { Percent of } \\
\text { Sales }\end{array}$ & $\begin{array}{c}\text { Total } \\
\text { Purchases } \\
(\$ 1000)\end{array}$ \\
\hline Plants and seeds & $9.7 \%$ & 292,372 \\
Containers & $4.9 \%$ & 147,095 \\
Growing media & $3.4 \%$ & 100,767 \\
Fertilizer and lime & $2.7 \%$ & 81,055 \\
Chemicals & $2.2 \%$ & 65,319 \\
Packaging & $2.7 \%$ & 81,510 \\
Other supplies & $1.8 \%$ & 53,115 \\
\hline Total expenses & $27.3 \%$ & 821,232 \\
\hline
\end{tabular}

Source: Hodges and Haydu 2006.

\section{$\underline{\text { Transportation and Distribution }}$}

Figures about transportation in the industry are not available in reports or surveys and the reader will not find a box for it in Figure 6. I include what is known about transportation because it is logically critical for getting product to market and appears to represent a bottleneck in the supply chain for many producers. It is speculated that large producers have developed in-house, large-volume delivery systems in order to service big-box retailers. But, even for these large producers, cross-country shipments are difficult because of the long time that plants are in trucks, and the extreme handling that takes place in many small orders (Hall et al 2005). My interviews with operators reveal an un-concentrated and unstructured transportation system for getting plants to consumers in Florida. In some cases, large nurseries are able to afford a fleet of trucks which facilitates product delivery - mostly within the state. Some of the operators I interviewed run small nurseries and often depend on brokers or buyers to transport the plants that they sell. According to one mid-sized nursery owner's account:

having a truck may often make the difference of whether you make a big sale or not. If you have the product the buyer wants, but no transportation, you may need to cut your profits in order to make the sale, since the buyer will have to pay for 
transportation or send his own driver. Companies with trucks are thus, better poised to negotiate with buyers, since they can include transportation in the final price.

\section{End Users}

End User is the name given to final buyers and consumers of nursery crops and floriculture products. The list of end users generally includes airports, cemeteries, churches, commercial general business areas, golf courses and driving ranges, homeowners, municipalities, private recreation areas, public state and county roadways, schools and universities, and utilities (Hall et. al 2005).

Among these end users an important source of revenue for the industry comes from the Florida Department of Transportation (DOT), which has a highway beautification project that relies heavily on products and services from nurseries and landscape firms in the state. By law the Florida DOT allocates at least $1.5 \%$ of the budget of any construction/remodeling of any highway project for esthetic improvements. According to the state FNGLA president, this law was the initiative of the FNGLA and was intended not only to expand the market for nursery producers and landscapers - which must provide continued services to projects - but to improve the quality of tourism as highways and important roads become scenic and colorful routes. This type of indirect subsidy via public funding has a secondary impact on greenhouse and nursery crop producers. Contracts go to landscape services, developers and contractors who in turn buy plants because plants are not necessarily purchased directly from nursery operations by the DOT.

\section{$\underline{\text { Research and Extension Services }}$}

Extension research and services play a crucial role in the dissemination of information to plant nursery producers. My interview with Miami-Dade County's commercial horticulture extension officer revealed that Extension links nursery operators 
to industry professionals in a variety of areas such as pest control, environmental and trade regulation, as well as government programs or industry initiatives. Extension services are available in all 67 Florida Counties, and managed by cooperation between UF/IFAS with County and State governments. Funding for extension programs comes from the counties and the state (Appendix $C$ lists all the extension office locations and contact information in the State of Florida).

\section{Professional Organizations}

As I mentioned in the previous section, despite a highly un-concentrated and fragmented industry structure, entrepreneurs of the plant nursery and landscape industry are well organized and represented in the state and national political process. This organization is highly related to the existence of a variety of organizations formed to represent the interests of industry-wide operators in the political process. Florida's most important organization is the Florida Nursery Growers and Landscapers Association (FNGLA). According to that organization's president, they now have over 2000 members and 7 divisions, 4 of which are growers of distinct crops, as well as landscapers, and allied suppliers. The organization, based in Orlando also has a satellite office in Tallahassee "to deal with the legislative and regulatory challenges and opportunities" 18 The FNGLA has an elaborate organizational structure with offices throughout the state, and with a rotation system of local chapter presidents which are themselves nursery operators. In addition, the Florida Farm Bureau also represents operators' needs in lobbying and public relations. The Farm Bureau is inclusive of all agricultural operations, and often rallies behind the nursery industry for a variety of environmental, trade, and labor regulations.

\footnotetext{
${ }^{18}$ Interview with Mark Sadek, FNGLA president. November 2009.
} 


\section{Discussion}

By understanding the structure of the industry we can see how products move along players of the industry and eventually make their way to end users. This is important because there is a highly complex and seemingly fragmented system of selling and rewholesaling before plants make their way to final consumers. In addition, this broader structural analysis demonstrates the interdependency of nursery/greenhouse firms with the other sectors of the "green" industry. These players include wholesale nurseries, field and container and greenhouse production, and sod growers, landscapers, landscape architects and landscaping, maintenance firms, retail garden centers, home centers and mass merchandisers with lawn and garden departments, as well as marketing intermediaries such as brokers, horticultural distribution centers, and rewholesalers (Hall, Hodges and Haydu 2005).

To fully appreciate the commodity chain and find potential pressure points within the plant nursery industry I believe it is essential to understand the place of nursery and greenhouse producers within the "Green Industry" (an appellation promoted by the professional business associations to denote nurseries and interdependent businesses). Nursery and floriculture production, which when taken together are usually classified as environmental horticulture within the Green Industry, are the focus of this dissertation because this is where the employers and workers of concern to me are concentrated. They are two sectors of a complexly inter-reliant structure of the Green Industry, which although they may produce some food crops (like herbs and vegetables for home gardens) are distinct from the larger agricultural industry that in Florida includes for example tomatoes, sugar cane and citrus. Besides nurseries, other important sectors of the Green Industry typically included in industry analyses include retail (like garden centers and big box stores), landscaping (from large commercial to small residential 
firms), wholesalers and re-wholesalers and brokers, and a variety of suppliers of seeds and raw materials for the production and installation of Green Industry products.

As this section on the Florida "Green Industry" highlights, crops tend to be highly varied and location greatly matters. For example, only in the far north of the state do Christmas trees tend to be produced, while in the central parts of Florida where ambient temperatures may drop to freezing part of the year there is a concentration of production in greenhouses, and In the far sub-tropical south one finds perhaps the greatest variety of crops because the climate allows more outdoor production while greenhouses are still used.

Many nurseries are involved in various other sectors of the Green Industry in addition to plant production. Some, for example, are also landscapers, many do direct retail sales, others are also wholesalers, many garden centers maintain greenhouse and/or field production, and some growers become suppliers particularly of seeds, liners (seedling plants) and cuttings. My interviews with producers also revealed an unconsolidated and unstructured transportation system. I draw attention to this issue since transportation emerges as a major bottle-neck for the majority of producers and demonstrates another way that the industry is largely unconsolidated. Figures about transportation in the industry are not available in reports or surveys. It is claimed by some of my interviewees that large producers have developed in-house, large-volume delivery systems in order to service big box retailers. But even for these large producers, cross-country shipments are difficult. Indeed, as one owner explained, "having a truck may make the difference of whether you make a big sale or not." Thus, the issue of transportation often puts smaller firms at a disadvantage while often poising others in better position to sell and market their products. This is also important, because those truck drivers do not belong to trucking companies, but rather tend to be on the payroll of 
nurseries and adding the number of potential workers reachable in an organizing campaign.

In the past decade some nursery firms have expanded their operations at the national level through acquisitions of other nurseries mainly to service these big customers. In Florida I found only allusions to a consolidation trend among nurseries in reports and interviews. According to the president of the Miami-Dade County FNGLA chapter, occasionally larger nursery operations have attempted to purchase other plant producers and gain a larger share of the market; however, he maintains that this does not represent the norm.

In terms of the relationship between growers and retailers, I did find a common complaint that large retail stores make the rules of the trade by imposing prices for products and reducing the profitability for nursery businesses. No data or estimates exist in the public domain about the value or volume of Florida nursery sales by retailers such as Wal-Mart, Home Depot, Lowes, or supermarket chains such as Publix and Winn Dixie. Certainly, these companies have taken a large portion of the retail sector which was traditionally in the hands of independent garden centers; yet, numbers are not available anywhere and it is difficult to quantify their real importance to the plant nursery industry. A thorough economic impact study could potentially reveal the importance of these operations within the industry and their strategic role for a campaign to improve working conditions and workers' rights.

My analysis also found important sources of government subsidies and protection. First, the Florida Department of Transportation (FDOT) has a highway beautification program that relies heavily on products and services from state nursery and landscape firms. By law the FDOT allocates at least $1.5 \%$ of its annual budget to esthetic improvements to highway construction and remodeling. The FNGLA takes credit for 
lobbying for this law and claims it is intended to expand the market for nursery producers and landscapers, which also provide ongoing services to completed projects, and to improve the quality of tourism by making highways and important roads scenic and colorful routes.

Second, plant nursery and greenhouse production are highly protected from international competition through a set of plant health (phytosanitary) restrictions. These measures prohibit the importation of any potted plant or soil into the U.S., and have been enacted to prevent the introduction and spread of foreign organisms and pests into domestic or native crops. These measures have important implications for plant nursery production in the State of Florida because: Unlike industries that can be transplanted to foreign countries in search of lower wages, weakened environmental restrictions, or feeble labor laws, nursery and greenhouse production has shown no signs of "withering away" because of outsourcing as has happened in a variety of other food, agricultural, and manufacturing industries in recent decades. For cut flowers and ferns (which are traded without roots) and for some species of orchids (which may be transported in sterile flasks) some phytosanitary exemptions do apply. This makes these industry sectors somewhat vulnerable to international competition and to any external pressure that may increase labor costs. In chapter five, I describe in detail the relationship between industry professionals, owners, and scientists and their discourses regarding regulation.

The plant nursery industry relies heavily on a labor intensive, immigrant labor force. It has become clear to me, through employer interviews as well as through the documents and opinions of industry organizations that a significant number of industry workers are undocumented and not legally permitted to work in the country. This has important ramifications for both the labor force and for employers, since: (1) for undocumented 
plant nursery and greenhouse workers, being undocumented constitutes a real fear of arrest and deportation, as well as increased vulnerability to harassment and exploitation at the hand of unscrupulous employers; (2) the undocumented status of many industry workers often decreases willingness and ability to organize, particularly since many workers are unaware or unfamiliar with U.S. models of organizing. Those who have a greater knowledge of U.S. organizing purpose and strategy are often afraid that their migratory status can represent an obstacle to joining such groups; and, (3) for employers, the undocumented status of much of the industry's labor force represents a precondition to breaking immigration laws through hiring undocumented workers in order to maintain a steady supply of labor. This is the theme of chapter 6 , where I use data from worker and employer interviews to better understand the interactions of producers and workers in the industry. 


\section{DEREGULATION IN FLORIDA'S PLANT NURSERY PRODUCTION}

On a warm Florida morning I had the opportunity to meet Mr. Craig Meyer, a Florida fernery entrepreneur who has had a successful business in Pierson since the mid1980s. Mr. Meyer comes from a family with a long history of agricultural entrepreneurship, and as he implicitly described it, has witnessed major changes in the agricultural industry in the State of Florida. Some of the changes that this entrepreneur often referred to were related to specific models of production that have withered in the state because of international competition. As he explained, "there used to be a lot of gladiolas grown in the state of Florida, but almost all those farms are closed down now, and that's because of foreign flowers coming' in to the U.S. There used to be a lot of flower farms scattered all across the United States, and pretty much they've been all... um... put out of business by South American flowers." Unlike ornamental plants produced in the State of Florida, cut flowers and cut ferns do not fit within agricultural quarantine regulations for U.S. imports because having been cut, they do not require soil for sustenance. The town of Pierson prides itself as the "fern capital of the World" and for Mr. Meyer and other fernery owners in the area, international competition has had a powerful detrimental impact on their industry. This has forced fernery operators to develop new business strategies and marketing channels to maintain the industry amidst a growing demand for internationally grown, less expensive ferns in the United States.

There is, however, another side to the story of fern production in the State of Florida where plant nursery production remains an important staple of the state's economic landscape. This industry creates revenue for state coffers through taxation, provides local entrepreneurs an opportunity to profit from the existing infrastructure, and creates jobs for thousands of administrative and low-wage agricultural workers. Because the production of ornamental plants is protected by agricultural regulations that prohibit the 
import of potted plants and soil, plant nursery production in the state of Florida might be seen as a process that is removed from the growing interconnectedness of the transnational economies of today. But can this industry be considered truly local? And if so, how has it been able to resist global trends, and what are the major implications real life and theoretical - that emerge from this seemingly localized island of antiglobalization?

In this chapter I explore the conditions that have contributed to the localized nature of plant nursery production in the United States in terms of production, distribution, consumption, and operation, despite increasing global trends to produce commodities where they are deemed more efficient and less expensive to produce. To this end I discuss my interviews with 20 professionals from Florida's plant nursery industry, including nursery managers and owners, high-ranking members of business groups and associations, and plant health regulators of the US Department of Agriculture (figure 7 shows the professional elite of the plant Florida plant nursery industry from which my sample of informants was selected). Whenever possible, I focus on the relationships that are forged between these three important sets of actors and conceptualize these relationships within a framework of discourses and professional practices that revolve around land production, market participation, economic development, and agricultural regulation. I begin the discussion with an analysis of the role that regulation plays on the attitudes and practices of industry professionals in a variety of local contexts, including an analysis of the role of sanitary and phytosanitary (SPS) regulations in agriculture in protecting the industry from international competition. I also analyze the values and discourses of plant nursery elites and the social interactions taking place between them to better understand their respective roles in strengthening their economic advantage for the survival of the industry. 


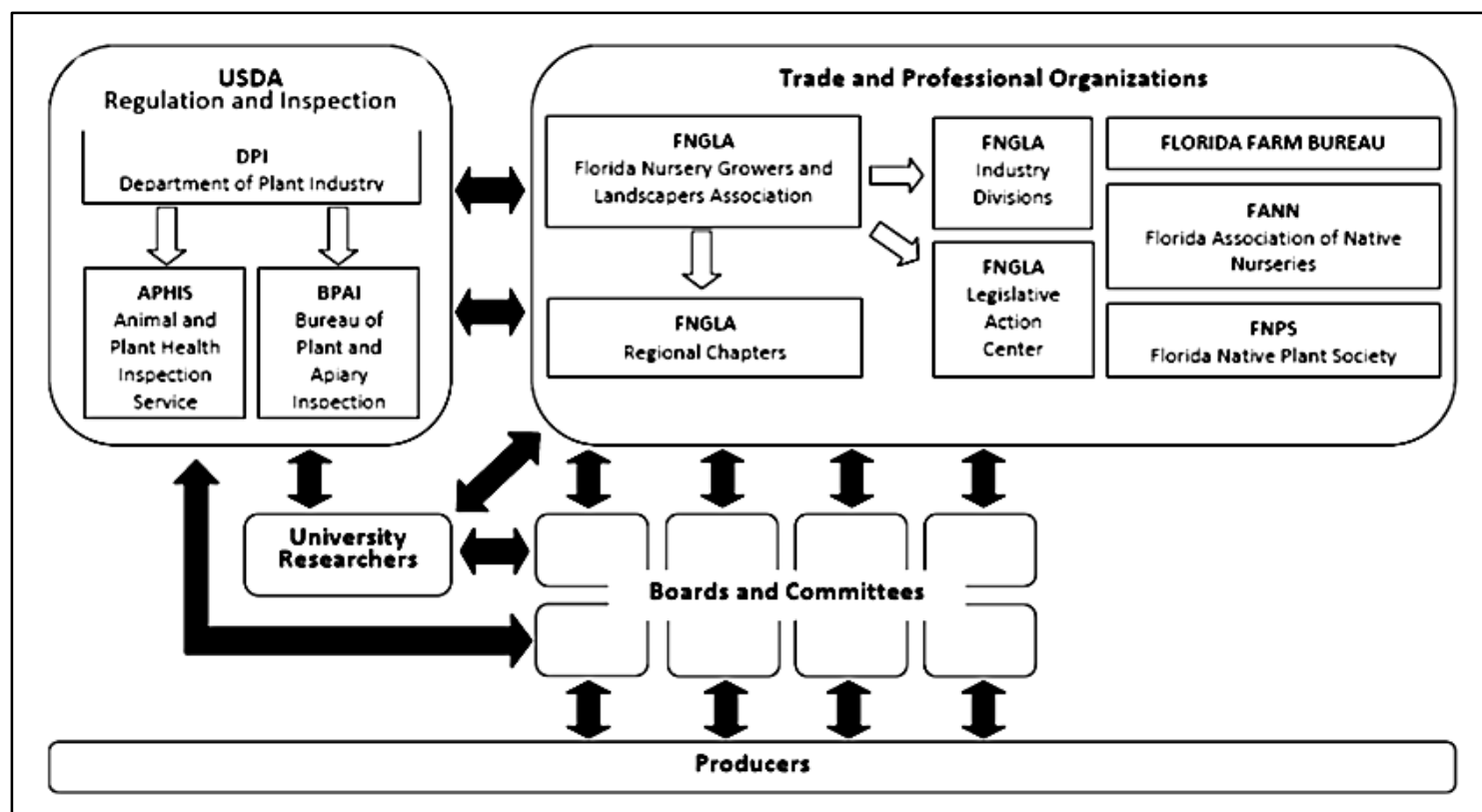

Figure 7. Configuration of Florida's Plant Nursery Industry Elite

\section{A Maze of Regulation}

When I first started conceptualizing this dissertation, I knew that agricultural trade regulation would play a key role in the framing of some of my research questions as well as my data analysis and subsequent discussion. But as I exited the field and began to re-conceptualize and analyze some of my original premises, I began to notice that a broader pattern of regulatory discourses had begun to emerge. In my interviews with industry elites, themes regarding competition with irregular or unregistered firms, interstate and international trade, scientific justifications for regulation, and the status of undocumented migrant workers who tend to dominate the labor force of this industry often emerged. These themes became important for my analysis because they helped me understand that the regulatory processes that support local production are not the only ones of concern to industry elites. This body of regulation is extensive and often arbitrary, as industry elites often take contradictory positions in favor of or opposition to a variety of regulatory practices. Still, they are an important aspect of the structure of the 
industry and shed light on the ways that values and discourses impact the institutional practices of industry actors. To this end, I discuss some of my findings in these four critical areas, before delving deeper into the processes which, I argue, create and maintain the conditions for the continued local nature and success of the plant nursery industry in the United States and particularly in the state of Florida.

\section{Competition}

The longevity of the operations provides ample proof of the stability of the industry at the state level. Within my sample of operators, the median number of years worked in the industry was 26, with most producers' years of experience ranging from 12 to 35 , with a single exception of a new entrepreneur with two years of experience. Most of the producers in my sample run small- to medium-sized operations ranging from two to six acres and employing anywhere from one to 25 fieldworkers. However, two of the operators interviewed managed large cooperatives which include up to six operations of up to 60 acres and up to 150 employees.

As in most business environments, competition among plant nursery producers is fierce and plays an important role in the conceptualization of the industry according to most producers. This should not come as a surprise in a business environment of any magnitude; however, the tone of the discourse of competitiveness among producers in Florida Nurseries is significant because it quite often gravitates around the issue of regulation, particularly that of firms and business practices. In my sample, operators often complained about the costs of production and profit margins as these seem to have a direct relation to the existence of small irregular operations that arguably bring down product prices in the marketplace.

Many industry operators in my sample argued that competition from irregular firms depresses the price of their products and makes it difficult to compete in the 
marketplace. Essentially, operators argue that irregular firms are able to bring down plant prices because they are saving a lot of money on the taxes, permits, and insurance costs that they avoid. George Gonzalez, a small farm operator in Miami Dade County told me that enforcement is one area where legitimate operators need some help. As he put it, "We need people to target these small backyard operations that are not doing things according to standard practice and don't have licenses and permits, and either make them comply or put them out of business." According to some of the operators, only a handful of code inspectors exist and they are thinly stretched investigating complaints and other kinds of violations.

To this end, Peter Smith, a 25 year veteran of the industry who owns a small operation in Miami Dade County explained to me that a lot of nurseries in the area lack insurance and are thus able to save a lot money that otherwise would need to be compensated through plant sales. Mr. Smith who has two full time, year round agricultural workers on his 5 acre farm described these irregular firms as "mom and pop operations where their kids come home from school and do all the weeding;" adding that having to pay over 20,000 dollars a year in insurance makes it very difficult to compete against them, "this is an industry where you can get your inventory for free if you go out and pick seeds and plant them and low cost competition is really big because it lowers everybody's prices." Similarly, Neil Rogers a business owner of 12 years who runs his operation on a 60 acre land complained about competition from irregular operations that do not follow procedures such as being licensed or insured, and thus avoid paying all the required permitting fees. This was particularly important for Mr. Rogers who employs anywhere from 12 to 15 workers a year and spends a considerable amount of money on worker compensation insurance. 
Lee Stan, a farm owner who has been in business for over two decades and at the time of our interview presided over the local Miami Dade chapter of the Florida Nursery Growers and Landscapers Association (FNGLA) argued in favor of a more normative system based on honor or value-enforceable practices around which producers could "unite" to maintain prices controlled. This prescription seems difficult in a competitive environment plagued by mistrust and jealousy. For instance, on several occasions I met with Jim Paterson, a recent nursery entrepreneur, to discuss a variety of issues regarding the industry. At the time I conducted the research Jim had been in operation for close to two years. Thus, he offered a prime view of some of the issues associated with nursery farming operations since he was beginning to navigate through the legal, political, labor, marketing, and technical requirements associated with the operation of his new business. On one occasion Jim explained that getting information from his neighbors was quite difficult, since these did not want to disclose prices, sources, or any information which could place them in a competitive disadvantage. This view was supported by many operators of the industry who often told me that their neighbors were jealous or cautious in regards to giving out information. In this sense, Jim's experience helps to illustrate the difficulty that operators like Lee Stan would have in producing a strong consensus that would maintain prices steady through an value-based normative or honor based system.

\section{$\underline{\text { Regulation of the labor force }}$}

In an interview with Mark Sadek, CEO of the FNGLA, Mr. Sadek told me about his belief that "the reason why there are so many illegal workers in the country is because there really isn't a legal way to come in and work." The spectrum of regulation in the discourse of plant nursery elites was evident in their preoccupation with immigration and labor. Nursery farm production is labor intensive and depends on a large contingency of 
immigrant and low-wage workers. A large percent of the Florida farm worker population is immigrant and overwhelmingly undocumented. According to Mark Sadek, the need for an immigrant labor force responds to "Americans' unavailability or unwillingness to work in such a labor intensive environment, even when there is $10,11,12$ percent unemployment." In the view of this professional and many other operators, the problem of undocumented workers lies in the policy itself, since having regularized workers would eliminate some of the problems associated with the status of workers and their control or regulation.

This theme constantly resonated with operators and industry elites, many of whom show distress in regards to some of the regulatory policies being established by the federal government to deter the hiring of undocumented workers. The Illegal Immigration Reform and Immigrant Responsibility Act of 1996 (IIRIRA) established a verification system to ensure that the information given by new hires matched the records of the Social Security Administration and the U.S. Citizenship and Immigration Service (USCIS). This program later evolved into the E-Verify program which is administered by the U.S. Department of Homeland Security in conjunction with USCIS, Verification Division, and the Social Security Administration. The system's application throughout the country is rather inconsistent, since some states and industries mandate its use, while others require voluntary participation by employers. However, for many in the nursery plant business, the program creates levels of enforcement that adversely affect the functioning of the industry. As Mr. Sadek explained to me, "Growers and businesses don't want to be penalized or fined. They don't want to be turned into police officials to determine whether documents are legitimate, which the law says right now, that documents must, on their face, appear to be genuine and related to the person who's applying." 
Other operators disclosed that the verification system only implicitly makes them accomplices of workers with fake documents, as they are constantly telling those workers that come up as non-matching to get a new Social Security or residency card. As one operator told me,

Every year the government sends a list of no-good social security numbers, and every year I have to go to my guys, who have been working here for more than five years, to tell them that you can't work here anymore, you haven't got a good social security number, goodbye, or give me another social security number, that one's no good. That has become my responsibility: to get a good social security number. And I do it every year. As far as I know, it should not be my responsibility to check, it should be the government's.

This operator's statement is representative of the opinions of other employers that I spoke with. All of the operators I interviewed were aware that a great deal of their employees are undocumented, and many explicitly confirmed that they look the other way or ask for new sets of documents when their names come up on the verification systems.

For Mr. Sadek, as for many industry operators, the only real solution would be to enact comprehensive immigration reform that provided a legal mechanism for hiring the immigrant workers they need. Specially, since current policies, they argue, only penalize operators who are trying to run successful business operations:

Growers don't want to have the specter of the federal government officials coming in and raiding their business operations, you know, penalizing them fines. And penalizing fines is one thing, but taking in workers in whom you've invested time and resources so that they're trained, you know, and their doing jobs that need to be done, that's the worse penalty. And the workers don't want to have the specter of federal officials hanging around. So for all those reasons, there needs to be some comprehensive reform to the immigration laws.

I probed Mr. Sadek in this regard, asking if having a comprehensive immigration reform could potentially affect employers because they would then be required to pay higher wages and provide benefits to certain workers who currently do not have them.

Mr. Sadek acknowledged my point and added that after IRCA, many agricultural workers 
left to other industries after they became legal; however, he argued that nursery work is already better remunerated than other forms of low wage work, which should suffice to maintain workers in the industry.

Most operators oppose the U.S. government's current efforts to regulate the hiring of undocumented workers, the employers advocate for a reform that would regularize the status of millions of workers. This seems clear, because it would prevent operators from having to enforce immigration laws themselves, and from having to operate with the feeling that the U.S. government is breathing down their necks. Supporting this scenario is of particular interest, since most elite actors feel that it is the government that should implement and enforce regulations to deal with the issues of immigration. Ironically, in this area industry elites advocate for larger federal involvement and policies that would free them from localized, fragmented, and semi-privatized ways of dealing with the situation of hiring undocumented workers that are in place today.

Agricultural trade regulation

From a regulatory standpoint, agricultural trade is one of the most important areas of concern for employers in the plant nursery industry. Agricultural regulations are said to have been enacted to protect local environments from exotic and invasive plant and animal species by restricting the types and amounts of live species (plant and animal) that can come into the country. These regulations are known as Sanitary and Phytosanitary (SPS) restrictions and have been used by a growing group of nations in conjunction with the establishment of a variety of global free trade agreements. SPS measures are intended to protect living beings such as humans, animals, and plants, from the dissemination of foreign, invasive, or exotic pests or disease that may come into a country through the import of agricultural goods (Burnquist, Barrs, Miranda, and Filho 2004). These measures have been sought to facilitate production and exchange, 
reduce transaction costs, and improve the quality of products; however, a variety of conflicts arise between domestic regulations and international trade policies, as the protective measures are often said to restrain international competition (Burnquist et al. 2004).

International SPS agreements are dictated by the World Trade Organization (WTO) and emerged after a large number of trade disputes between developed and developing countries. Many disagreements could not be resolved under the General Agreement on Trade and Tariffs (GATT) Standards Code or through the existing dispute settlement process. Such disagreements often emerge from conditions in the SPS agreement itself, which asserts the rights of states to protect themselves from risks associated with SPS conditions. The agreement gives nation states ample room for interpreting what kind of risks threaten their biological wellbeing when foreign live products come into their borders, but distinguishes between protection and protectionism, which is defined as trade regulations that go beyond reasonable protection from biological infestation or disease. These measures, according to the Agreement, shall not discriminate against trading partners of identical or similar quality conditions and cannot be maintained without sufficient scientific evidence that ensures their adequate level of protection (Burnquis et al. 2004).

These definitions, however, create contradictory implementations within the SPS agreement since hardiness zones as well as pest or disease free-areas are mostly determined by geographic conditions and not by political borders. Thus, they may be part of a single or several countries which share common borders, dictating that "import protocols should be based on a risk assessment that evaluates claims by exporting countries that certain regions are free of quarantine diseases or pests, or that prevalence of quarantine pests and diseases is low" (Burnquist et al 2004:168). It is still 
left to the importing country to decide which geographical areas and products are considered safe for import into the country; but, as developing nations often argue, this creates uneven and artificial market conditions, since powerful nations are still able to mandate which products may enter their territory for sale and distribution.

To illustrate this imbalance in the trade policy, we could look at the way in which plants grown along the southern part of the U.S.-Mexico border could safely be sold, traded, and grown in the northern side of that border because political demarcation does not interrupt the environmental conditions of that geographical area. Plant pests and disease are contingent to those geographic regions and no form of geo-political demarcation would be able to constrain their dissemination across international borders. Yet, in the U.S. a well-organized system of regulation has been established, organized, and enforced through a variety of governmental agencies such as the Department of Homeland Security (DHS), the Division of Plant Industry (DPI), or the U.S. Department of Agriculture (USDA), and validated by the scientific, political and economic discourses that are reproduced and maintained by employers, business elites, and scientists of the industry as well.

As an example, we can look at the way in which these regulatory practices have taken on a new meaning in the aftermath of the terrorist attacks of September 11, 2001, which produced a discourse of "National Security" by political elites and in effect created another layer of control and regulation in many activities surrounding agricultural trade. Prior to the attacks of 9/11, the Plant Quarantine Act of 1912 banned any individual from importing or bringing nursery stock into the U.S. or receiving any nursery stock moving from a foreign country into or through the U.S. (Musgrave and Flynn-O'Brien 1988). The act had several amendments, until 2000, when The Plant Protection Act (PPA) was established as part of the Agricultural Risk Protection Act. This law consolidated all 
existing USDA plant health regulations into one inclusive law, including the authority to regulate plants, plant products, certain biological control organisms, noxious weeds, and plant pests (www.aphis.usda.gov 2000). Then, in the aftermath of the terrorist attacks of 9/11, the Bush Administration placed portions of the USDA's Animal and Plant Health Inspection Service (APHIS) under the jurisdiction of the Department of Homeland Security (DHS) in its efforts to increase federal protection from terrorist threats.

Recent changes in policy and control were described to me by Paul Roth, Director of the Division of Plant Industry (DPI) in the state of Florida, who describes his organization as the plant protection and quarantine arm of the Florida Department of Agriculture, and which "was established to protect the state's native and commercially grown plants, as well as the honeybee industry, from injurious pests and disease." According to Mr. Roth, "Customs and border-protection, which is a branch of Homeland Security, now do all the agricultural quarantine inspection on incoming cargo, and incoming passengers." Before 9/11 the department of agriculture enforced the agricultural quarantine regulation at ports of entry, but their focus after 9/11 was terrorism and drug interdiction; consequently, as Mr. Roth explains, agricultural pest and disease concerns became a distant third. This sentiment resonated with some of the operators and regulators in the industry who feel that the USDA should be in control of the agricultural regulation. For Daniel Richardson, a 40 year veteran of the industry, the move of agricultural regulation to DHS is problematic because the larger law enforcement agency "does not necessarily have expertise in identifying pests and diseases on plants." In this operator's view, the move is political and overextends the role of government on business activity. Similarly, Lee Stan, the former chapter president of the Miami-Dade FNGLA expressed that the DHS should "go after the stuff that they need to go after to keep our country safe and let USDA go after the pests and diseases to keep American agriculture safe." 
The discourses of industry elites in regards to the enforcement of SPS regulation again serves to demonstrate the ambiguity embedded in the regulatory views of industry elites. Clearly, industry actors are not dissatisfied with the federal government's enforcement of the policy, but with having the DHS as the enforcement body of the regulation. In addition, the permanence and enforcement of the law at the federal level allows producers the peace of mind that they will not have to negotiate with fragmented or contradictory state systems to enforce the regulation. This also demonstrates the degree to which SPS regulation responds to larger sociopolitical conditions, since SPS regulations provide an ideal competitive advantage to plant nursery producers in the U.S., and more specifically to those in U.S. states which share hardiness and ecological zones with developing countries, which would be more at risk of losing their production to nearby foreign regions.

The conditions that facilitate the creation and enforcement of SPS regulations are thus socio-cultural and political, as they respond to a combination of political challenges and the socio-cultural processes established to mitigate their impact. But how have these geo-political agreements been able to withstand global trends toward trade liberalization? And more specifically, how have they been able resist the move toward outsourcing production to peripheral and semi-peripheral centers where labor and environmental costs are cheaper, as well as the complaints of developing countries who feel that the use of SPS regulations in the U.S. undermines the free trade agreements in which they have entered?

\section{The Science and Values of Regulation}

Industry producers and scientists overwhelmingly support the existence of regulation that protects the industry and the Florida ecology from risks associated with the import of plants and foliage from international sites of production. While many plant nursery 
operators acknowledge the role that the Plant Protection Act plays in the survival and economic success of the industry, for industry scientists, regulation is justified from what to them represents a scientific and means tested approach. Despite the fact that there are several layers of regulation, which range from local issues to state and international trade and political conditions, for the most part, elite actors advocate for an environment of strict regulation as a means of maintaining the economic and environmental health of the industry. In the discourse and attitudes of operators, scientists and business elites, these justifications correspond to the language on the SPS agreements which advocate for a scientific justification for the policies established in trade protocols.

For operators like Peter Smith, SPS regulations make sense for industry survival. As he explained, "right now we are protected as far as NAFTA goes because soil is not allowed to be brought into the United States. If and when soil comes into the United States we would... you know there'd be plants coming from South America and we just won't be able to compete at all." Operator Jim Scott, emphatically agreed: "[l do] not want to see soil come in, and not for the economic issue alone, but for the fact that it will literally wipe out our industry". These owners' conceptualization of the need and value of SPS regulations is twofold. First, both operators acknowledge the economic implications that having a regulation of imports entails to the economic success of the industry; however, Mr. Scott's perspective also highlights the ecological implications associated with the impact that foreign pests and organisms would have on the health of plant life in the state, basically arguing that plant life could be decimated by the entrance of invasive plants or of pests and pathogens that could destroy the plant varieties that keep the industry alive.

In a conversation about regulation, Mr. Scott further explained his perspective about SPS restrictions as follows: 
Jim: there is something called quarantine 37 . Are you familiar with it?

Alejandro: uh, somewhat....

Jim: ok, quarantine 37 prohibits material coming from offshore that has any native soil; prohibits material larger than 24 inches; it can come here with roots but it cannot be larger than 24 inches; if it's larger than 24 inches, it cannot have any roots and it cannot have any foliage.

Alejandro: so, they should be cut already.

Jim: correct, so that's how is typically done. The reason for the quarantine 37 is very simple, I don't know the exact numbers, but the numbers are pretty extensive; see, the number of pests that come into this country from foreign countries is massive and most of them are coming through the port of Miami, because that's where the bulk of cut flowers are coming through. So it was a conscious decision to try and limit the number of incoming pests, and that, for the most part has done its job.

For this owner, the relationship between regulation at the ports and the contention of foreign pests and organisms is clear. However as he later admitted, some pests come in to the state "more than likely through hurricanes or debris that happen to blow in, I mean this is more of rarity, but, you know, bugs do get in." In this sense, Mr. Scott's understanding of the regulatory conditions conveys an admission that the expansion of pests across geographical areas is affected by larger environmental factors such as winds, hurricanes, and sea currents; and, thus, concedes that using and enforcing SPS regulations is a conscious decision only to limit the number of pests already coming in through trade of cut foliage or fruits.

In this sense, regulation not only has an economic value in terms of protectionism, but also because for producers, lax restrictions could mean an increase in the costs associated with pest control at the farm sites themselves. As Mr. Scott explained, "if you see the number of additional pests that we are having to spray, you know all we are doing is spraying every day and you don't want to necessarily do that." This statement demonstrates yet another layer of consideration in regards to the liberalization of market activity, since for this operator having plant imports and the pathogens that they may bring in with them would also signify an increase in time and materials required for pest 
control. This point, although economic in nature, also fits with the conditions that allow nation-states to decide the level of enforcement within the international SPS agreements. In addition, this also raises the question of who shall be left with the tasks and costs associated with increased fumigation, as control of pests and insects outside nurseries and farms could result in increased costs for the regulatory agencies at the state level as well.

Scientists and industry regulators are also well aware of issues surrounding regulation. However, unlike the owners, the regulators more directly emphasize the role of science as the mechanism through which SPS regulation is informed while downplaying the role of political arrangements in the decision making process of trade regulation. Paul Roth, the director of the Florida Department of Plant Industry (DPI), explained how trade regulation is primarily a federal requirement, "The way the federal government sets their standards is based upon sound science or risk, but it all comes down to justification, and scientific validity has to back up what you're doing." Similarly, Troy Miller, Florida director of the Animal and Plant Health Inspection Service (APHIS), explained that scientists in charge of regulation make their decisions on sound science and previous empirical experience of what has worked before. Mr. Miller, however, was more open about the problematic nature of regulating from a scientific stance amidst a political establishment. Mr. Miller's agency is responsible for the protection and promotion of U.S. agricultural health, regulation of genetically engineered organisms, the administration of the Animal Welfare Act and other broad wildlife damage management activities. As the state's main regulator, Mr. Miller explained that although states cannot go above and beyond federal requirements, regulatory decisions need to be inclusive and hear from the other producing states and their industries, which, as he acknowledges, lobby and pressure legislators on behalf of their interests. 
I probed Mr. Miller in this regard, and although he showed a clear understanding of the multiplicity of layers involved in the decision making process, he continued to emphasize science as the principal mechanism to institute regulation, while downplaying the power of economic and political motives. Mr. Miller continued speaking about this multiplicity of layers:

I can't really cite anything specific where the political winds have sort of guided or changed what we wanted to do; that's not to say that that hasn't happened or there's been a nudging of policy, but it's not a daily thing that we see you know. I don't know everything that goes on behind the scenes obviously, but I mean the things that I've been directly engaged in have been pretty solid with science, with regulatory procedures, with history, so I really can't, can't say that we're unduly influenced by the political whim, so to speak.

Mr. Miller admitted that there are political factions at play to promote regulation through lobbying; however, his sentiment is that it is ultimately science that informs the regulatory process. This was the view accepted by most of the industry elites with whom I spoke during my fieldwork, and in this sense, the state elite actors seem fully aware of the relationship between the political and geographic contradictions that the issues of regulation present, but their answers tend to de-emphasize the process of socio-political interaction and emphasize what they claim to be a scientific basis of regulation.

The scientific rationale was only sporadically challenged by the industry operators that I interviewed. The topic, however, was the center of conversation in several operators, including Daniel Richardson in Miami Dade County. Mr. Richardson has been in the ornamental nursery business since 1970, and now leads a cooperative of operations with other investors in over 250 acres of land across South Florida. In many ways, Mr. Richardson fits a stereotypical philosophical and political conservative businessman profile and is quite supportive of free trade -or at least trade that is unrestricted by governmental institutions. Because of the size of his operation, Mr. Richardson is well positioned to supply the Home Depot, Lowes, and other large garden 
center and plant retailers across the country. In addition, he is well versed on, and critical of, international trade regulation of fauna and flora.

Mr. Richardson criticizes the way in which the federal government has stepped into trade regulation based on science. The issue, he argues is that because of new technologies scientists are finding new funguses and diseases on a regular basis and thus facilitating the process for political actors to regulate products coming into the country and even from state to state within the U.S. As he explained,

The government is actually controlling the free trade. Nowadays in order to ship, it depends on what [U.S.] state the product is going to. You a need snail certificate to ship to some states, you need a phytosanitary certificate to ship to California, you can't send Queen Palm trees to Texas because lethal yellowing disease wiped out all our coconuts. This is ridiculous, Texas had Queen Palms on their list and I was livid about it, so I got ahold of the director of the Department of AG in Texas and explained to him that this palm tree does not get this [disease]. They were restricting free trade and, you know, they took it off.

Mr. Richardson also told me about his suspicion that the whole Queen Palm incident in Texas was the result of Senator Lloyd Bentsen who owned large tree operations in Texas and did not want out of state products there to compete; as a result, Richardson argued, the politician used his power to justify regulation based on misconstrued scientific foundations.

Jeff Brown, chief of the Bureau of Plant and Apiary Inspection (BPAI) also brought up the issue of trade regulation. BPAI can be described as the inspection arm of the DPI and is responsible for protecting Florida's agricultural industry and the public from the introduction and spread of serious plant and apiary pests through the enforcement of Florida statutes and departmental rules pertaining to the movement of plants, plant products, honey bees and beekeeping equipment. In sharp contrast with Mr.

Richardson, Mr. Brown believes that the industry is not sufficiently regulated and explained to me that "new stuff [pathogens and pests] is coming in all the time, you got 
all this fruit fly issues, and we are finding new kinds of pests all the time, all coming in from other countries. So what happens when it gets to Miami? It spreads. It happens all the time." When I probed about the opinions of certain farm operators who believe the government is over regulating, Mr. Brown justified his line of work by expressing that "Nobody likes rules and requirements, there is a lot of nurseries out there, that don't want to follow the specific guidelines, and you know, our regulations are guidelines, really basic. We are not here to over regulate, not even close."

In my interviews with the state's regulators, I often inquired about the seeming arbitrariness that exists in the decision-making process, bringing up the notion that a political line between Mexico and the U.S. could not fully justify the cutting point for risky or healthy production of plants. At the end, for elite actors there exists a consensus that the infrastructure, science, and quality of the industries in developing countries should somehow account for the quality of their products as well. As DPI's Paul Roth explained, "there are some better developed nations that have very good phytosanitary systems. The United Kingdom and Australia are at the top of the list, and New Zealand has a very good program. You can contrast these with some of the poor African nations whose department of agriculture would fit in this room; they just don't have the infrastructure." This scientist's view seems to indicate a hierarchy of valuation embedded in what he perceives to be the development of a nation and their ability to enforce a variety of SPS codes. This again seemed arbitrary to me because it is the geography of an area that contains a series of native pathogens; thus, moving products from the areas south of the U.S. border into California or Texas, should not pose any real environmental threat. In addition, the belief in scientific evidence should also indicate that a well developed certified program abroad could account for good controls of the products coming into the country. 
In an interview with Paul Roth, the State's DPI chief, the issue of arbitrariness in regulation emerged implicitly as he tried to further convey the idea that science and empiricism should inform the process of regulation:

Well, again, an example is bringing in a new plant from offshore into the nursery industry. The university has a group of scientists that look at invasiveness of plants, and they say, well you don't wanna bring that in because it's potentially invasive. Well, what does 'potentially' mean? You know, it might be invasive in Sri Lanka, but it's not going to be invasive here because our climate is different or, or whatever. So I, I get a little bit disturbed when people want to over regulate based upon the unknown or because unknown potentials that could occur. I'd rather have some sound scientific documentation. An example is biomass. Nowadays everybody wants to bring in new plants to grow for energy. Well, Lykes Brothers, which is a big agro business company, has been growing eucalyptus for about thirty years down around Seabring [Florida] and they have fifteen thousand acres of it for forestry use and it's not invasive, it's been there for thirty years and it's just not invasive. But, now they want to add biofuel use to require a permit from my department. And the environmentalists are saying, we don't want you to permit this because it's potentially invasive. And I say, wait a minute now, they've had it for thirty years, and they've got fifteen thousand acres and it's not invasive. So, you got to have real-world experience versus other things and, and make a judgment call.

As a scientist and regulator, Mr. Roth seems well aware that even foliage that is exotic to the state could be safely grown in local farms, as long as the evidence is there to substantiate its safety. He further admits that regulating on grounds of "the unknown" ${ }^{19}$ is problematic because it can lead to overregulation of trade activity. However, most of the regulation on imports from developing countries is based on this premise and ignores the prescriptions of scientists and regulators toward protectionist policies that benefit national growers. Most importantly, Mr. Roth's statement presents a series of new actors that contest the decisions and practices of the process of regulation. He acknowledges the motives of university researchers and local environmentalists who advocate for

\footnotetext{
${ }^{19}$ Regulating based on the unknown refers to the practice of creating barriers to the trade of plants and foliage with little or no evidence that they will be destructive to local ecosystems. This premise is often used by developed nations to prohibit the import of foliage from developing nations, arguing that the lack of evidence of the invasiveness of the plant is sufficient to prohibit its importation.
} 
different courses of action, while criticizing them for what he understands to be a lack of empirical experience.

This example further demonstrates the scientists' view in regards to what they consider to be proven science and experience to regulate imports. Mr. Roth was often hesitant concerning the science of regulation and its political implications. He sometimes stuttered or seemed anxious when I pointed to the arbitrariness of some of the regulations, but his answers nonetheless justified the existence of regulation from a scientific stance. As Jeff Brown, chief of the Bureau of Plant and Apiary Inspection (BPAI) told me, "the idea is not to over regulate, but to ensure that scientific guidelines are what inform the decisions that lead to regulation." The scientists reinforced this view even when talking about the influence of politics and economics on the regulatory process and in turn legitimized the protection of the industry from international competition through what they understand to be a strictly scientific point of view.

The discourse of regulation is central to the maintenance of the plant nursery industry in the U.S. and in those states that benefit greatly from this type of agricultural production. As my interviews with industry professionals indicate, while powerful industry actors advocate for an environment of strict regulation as means to maintaining the economic and environmental health of the industry, such justifications are based on a discourse of science and what they consider proven empirical methodologies. In this sense, industry elites do not have to justify the protection of the industry from a political stance, since the scientific data justifies local production based on the protection of native ecosystems, which should be kept protected from pests and invasive species coming from abroad.

The scenario I have outlined in this section demonstrates a rather unified discourse that shapes the professional practices of nursery operations and the power structure of 
the industry, as the goals of producers and regulators often coincide under a series of values and norms about industry and environment. Through their discourse, the scientists portray themselves as unaffected by political involvement in industry decisions, which to them are dictated by scientific data. In this sense, the scientists promote an atmosphere of regulation that prohibits international competition, stimulates a level of economic protectionism, and aligns the values, economic goals, and professional practices of producers under a rather homogenous code of regulation.

The questions of why and how Florida has remained one of the most important sites of nursery plant production for the US market, despite the widespread neoliberal economic restructuring of the last three decades that moved many similar industries out of the country, hinges largely upon regulatory frameworks that are shaped by local actors. Part of the problem in broad, structural globalization analyses lies in the conceptualization of the regulatory process as one of exclusively geo-political or of economic implications. Those macro level approaches, however, ignore the ground conditions that encourage the resistance to specific neoliberal economic trends at particular localities. Specifically, they disregard institutional arrangements which are embedded in socio-cultural interactions and which unify social agency around a variety of common norms, values, and goals.

Within this expanded framework, the structural implications of SPS regulation for the plant nursery industry of the state Florida are multiple; specifically, since they affect and are affected by a variety of actors within the industry's institutional framework. For scientists, regulators, producers, lobbyists, and even workers, the nature of regulation takes on a variety of meanings, which, are justified and embedded within a variety of discourses and result in very specific professional practices. In the following section, I address those institutional arrangements, demonstrating how the discourse and 
interactions of the Industry's elite shapes and legitimizes those macro-structural arrangements that keep the industry local and protected from international competition.

\section{Political Arrangements, Interest Groups and Resistance of Traditional Firms}

Nursery plant production in the state of Florida is largely composed of small and medium sized independent firms; and while some firms have grown to achieve large operations in terms of land and value, these tend to remain independently owned.

During my research I found no evidence that publicly traded firms are parent companies to smaller nurseries or groups of nurseries; in contrast, the structure of the industry is complex, inter-reliant and without significant consolidation. In Florida, a relatively high proportion of small and medium sized firms account for a significant share of industry production and value with a diverse array of commodities and market channels exacerbating the unconsolidated nature of the industry. This scenario often prevents a variety of organizational efforts such as cooperatives and collective marketing strategies (Hodges and Haydu 1992). This seemingly fragmented structure is a key element in the institutionalization of industry policies, for it conceals the process through which such an unconsolidated industry is able to resist global trends in production.

More importantly, the process of industrial permanence and success can be said to respond to the embodiment of SPS regulations into quarantine 37 , which is widely cited by operators and regulators to explain the stability of the industry in the U.S. However, the issue with quarantine 37 is that it responds to a variety of transnational polices, enforcement bodies, and levels of operation that undermine many of its environmental premises and which are adjusted politically to fit within the economic aspirations of those who benefit from its enforcement. In this sense, the maintenance and ratification of quarantine 37 responds to political actions at the state and federal level, which require a large organization of sponsors and supporters to navigate the governmental 
policymaking process. As it has been demonstrated by a variety of observers, policy making in the U.S. often responds to the pressures of large conglomerates through the lobbying of public representatives. But nursery plant production in the state of Florida does not fit such an institutional model, and thousands of small operators must find strategies of resistance to participate and influence the political model instituted by powerful industrial actors.

Despite its fragmented industry structure, entrepreneurs of the plant nursery and landscape industry are well organized and represented in the state and national political process through professional business associations such as the Florida Nursery, Growers and Landscape Association (FNGLA), the American Nursery and Landscape Association (ANLA), and the Florida Farm Bureau. The most significant of these associations is the FNGLA, which according to its CEO, Mark Sadek "is the trade association that represents Florida's nursery and landscaping industry." Founded in 1952, the FNGLA is based in Orlando with a satellite office in Tallahassee and deals with "legislative and regulatory challenges and opportunities." The FNGLA has more than 2000 members distributed in 7 divisions, which include: the Allied Division, Citrus Nursery Division, Foliage Division, Floriculture Division, Garden Center Division, Landscape Division, and Woody Division. In addition, the organization has 16 regional chapters, which provide a large presence throughout the state.

The presence and visibility of the FNGLA through the entire state of Florida is easily perceived, as its set of divisions responds to what Mr. Sadek argues to be a wide range of needs, including, "small business issues, tax issues, labor issues, land issues, water, pests and diseases; everything from land use to the tax assessment of lands." In repeated occasions, my snowball samples led me to the organization and its local chapters, as most operators and elite actors from my sample referred me to them as a 
valid source of information regarding nursery issues. The FNGLA amplifies its state presence through the use of industry shows, educational events, annual conventions, certifications, community programs, and research. These strategies are also key for the development of networks and the formation of elite groups that are able to influence policy on behalf of thousands of small operators. As Jim Paterson, the newest entrepreneur within my sample told me,

There is a network through the FNGLA, there are people that are somewhat active in the organization and I think to be a part of that and to be seen as part of this group you know this family of nurseries I think helps, helps me to feel like I'm part of a subgroup within the nursery business and I feel like the big business, the more legitimate business, I mean all the big successful people are members.

Like Jim, many other operators felt that the FNGLA provided them with information and support necessary to succeed in the industry, even highlighting the role that the organization plays at the political and regulatory levels. This was articulated by MiamiDade operator Daniel Richardson who told me that he was a member of the Farm Bureau and FNGLA because of the power they have been able to achieve through lobbying in Tallahassee.

Although Florida is the third largest nursery producing state in the country, after California and Texas, the FNGLA is the largest national nursery and landscape association. The FNGLA has a strong political center and a variety of programs designed to influence policy and inform public opinion. This is done through the support and establishment of a variety of blogs, policy papers, information hotlines, and member newsletters; a Political Action Committee, which funds political candidates that are sympathetic to the industry; and the Green Industry Coalition, which brings together a group of representatives from a variety related groups, including the Florida Chapter of the American Society of Landscape Architects, Florida Turfgrass Association, Florida Landscape Maintenance Association, Florida Irrigation Society, Florida Sod Growers 
Cooperative; Florida Golf Course Superintendents Association, and the Irrigation Association.

At the political level, the FNGLA spends valuable resources in lobbying and supporting candidates. A look at the organization's website reveals that for the 2010 governor's race, they supported both the Democratic and Republican Party candidates. In terms of lobbying, Mr. Sadek indicated that they have opened up a permanent office in Tallahassee and retained lobbyists up there for several years, particularly since "the industry has matured and the stakes are high." In addition, Mr. Sadek told me that the FNGLA works as part of the AG coalition, which is composed by the "the lobbying representatives of the various AG associations in Florida, some of the bigger companies in Florida get together on a weekly basis, leading up to the legislative sessions each year and during the legislative sessions." This is important according to Mr. Sadek because Nursery production presents different challenges and opportunities compared to agriculture, and the nursery industry must "stand shoulder to shoulder" with this other influential industry group,

In terms of state regulation and policy, the work of the FNGLA is often acknowledged by its industry operators. Lee Stan argued that the FNGLA has been influential in areas related to easing water restrictions for commercial nurseries, and restructuring harsh crop insurance regulations which were hard to comply with because of excessive demands and controls on nursery operations. But the role of the FNGLA does not stop at the state borders. A look at Mr. Sadek's personal blog reveals the extent and influence that the organization has been looking to achieve at the federal level. The following is an excerpt from Mr. Sadek's blog in 2007:

It isn't a stretch to say FNGLA is profoundly influencing the State of Florida and its view of our industry. Yet, FNGLA's political advocacy does not stop at the state border. Just last month, FNGLA's president Paul Polomsky, president-elect Dave 
Self and I were in Washington seeing and meeting with no less than 14 Members of Florida's congressional delegation -- including our two U.S. Senators: Bill Nelson and Mel Martinez. The focus of our discussions was two-fold: (1) our nursery \& landscape industry's compelling need for comprehensive immigration reform; and, (2) our industry's priorities for the every-five-year federal Farm Bill -- the operational framework for all of USDA's programs.

Traditionally, the Farm Bill focuses on: (1) crop subsidy payments for the big Midwestern program crops; and, (2) the multi-billion dollar food stamp program. The Farm Bill typically ignores so-called specialty crops -- nursery, fruits and vegetables. Our industry proudly does not want any subsidies. Period. Yet, FNGLA does want to see more attention paid to the threats posed by foreign pests and diseases, as well as more research to address agricultural and landscape challenges. Research is a very appropriate role of our federal government. With this squarely in mind, we met last month in Washington with both the U.S. Deputy Secretary of Agriculture and the Chief-of-Staff to the U.S. Secretary. FNGLA's meetings were very productive in positioning our industry's issues as the Farm Bill debate begins.

What are FNGLA's priorities for the Farm Bill? Topping the list is maintaining a strong Quarantine-37 as our industry's first line of defense against the introduction of business-disrupting foreign pests and diseases. Another priority is USDA investing dollars in research. In fact, the Bush Administration's Farm Bill proposal has just proposed investing $\$ 1$ billion in specialty crop research. FNGLA is also pushing resolution of several risk management issues: make nursery eligibility permanent for two of USDA's disaster assistance programs -- ECP debris clean-up and TAP assistance for tree growers.

Mr. Sadek's point of view is emphatic in that the industry is not seeking any type of

Federal Farm Bill aid. However, the CEO underscores the discourse of Homeland Security enforcement of quarantine 37 to justify the continuation of the policy as a mechanism of prevention to the introduction of pests and diseases that could adversely affect it. In addition, Mr. Sadek, calls for a continued flow of cash for research conducive to the strengthening of the regulatory policy and highlights his organization's efforts to include the nursery industry in a variety of disaster assistance programs that would directly benefit industry producers. In his blog and other public comments, Mr. Sadek explicitly brags about the industry's economic value, and rationalizes it as an influential point to lure policymakers into protecting the industry and its players.

With its multifaceted approach, which includes, research, networking, education, community engagement, and a well delineated political agenda, the FNGLA has been 
able to position itself as a pervasive and imposing force within the state's political machinery. They have conveniently and successfully situated themselves as the unifying mechanism for local producers to achieve collective goals in policymaking and regulation. In part, they have achieved this by further aligning their values and discourses about regulation with the professional practices of industry operators and scientists under a message that encompasses proven science, economic prosperity, and national security.

The FNGLA commands a faithful group of members that see in it a defense against structural forces that endanger their economic survival. Several operators and industry elites often expressed their concern for economic policies that respond to international pressures, and in this sense they argue, the representation that the FNGLA provides is essential in keeping the industry safe from policies that may weaken it or disintegrate it. It is still to be seen how the industry is able to align such values, discourses, and professional practices. In the following section I analyze the close relationships and interactions that are forged between elite industry actors, emphasizing in the process through which they have come to depend and rely on one and other for policymaking, regulatory enforcement, and the industry's own "institutional survival."

\section{Bonds of Dependency and the Formation of Regulatory Regimes}

Most of the scientists and operators in my sample expressed great respect for the process through which policy making in the industry takes place. Although they readily admit to glitches on the system, they overwhelmingly think of the process as inclusive, transparent and democratic. As I argued earlier in this chapter, scientists firmly believe that their science and research gives the foundation for the enactment and enforcement of policy and regulation. Similarly the operators and industry professionals I spoke with trust that they, as the people that grow the goods, "know best" and that they have a 
voice in the policy making process through their professional and lobbying organizations. But how is it that these actors are able to work together through the layers of local, state, and federal regulation that span from labor and trade to environment and taxes? And are the values of transparency and democracy expressed by industry elites to account for this seemingly harmonious process of decision-making?

From my interviews with industry elites, I was able to observe that a strong and stable regulatory regime has been cemented in the industry, as many of the industry's main regulatory and professional actors create strong bonds of dependency through a series of social networks. From the local to the national levels and in a variety of areas of concern, most industry elite actors participate in what could be described as a web of networks of influence. The majority of operators and all of the higher ranking elite actors whom I interviewed actively participate in a variety of formal boards and associations, which directly and indirectly shape industry policy and regulation. In this way, elite actors are able to command consensus and authority and facilitate the formation of a regulatory regime that mostly serves the interests of the business class. Through this system, Industry elites are able to disseminate information, convey resistance to policies enacted from above, and to align their discourses under a unified code of professional practices. To this extent, Mr. Sadek, the FNGLA CEO maintain that generally "there is a good ebb and flow between growers and the inspectors and the regulators" in the industry, who must work together in identifying things of quarantine significance.

As a part of their primary responsibilities as regulators, many industry scientists also perform tasks associated with consulting and advising for political, educational, and business interests. This takes place through a well-established system of chapters, boards, meetings, and even internships, in which elite actors participate and remain connected with other industry actors. For instance, Paul Roth, the state's DPI director 
explained that he represents the state in the National Plant Board, which is an umbrella organization for state plant protection officials. Mr. Roth adds that this is the platform where the principles of plant quarantine are adopted and become the "guiding documents that all the states try to follow for consistency purposes." In addition, other scientists and professional elites cooperate in a variety of plant boards that are regional while others spoke about specific state plant boards.

Because states can regulate their own industry as long as regulations do not surpass federal policy, a process of decision making must also be established at the state level. When I asked Mr. Brown at the BPAI about how this process is handled by the state's regulatory officials, he explained that as in a balancing act, he must cooperate with entomologists, pathologists, and a support team to respond to changes being studied by the USDA. This participation with other scientists keeps Mr. Brown informed and connected to other industry insiders; however, as he and other industry regulators explained, they often sit in boards of industry organizations that have non-scientific objectives. Mr. Brown for instance, told me that he sits on the board of the Farm Bureau, providing scientific support for legislative decisions and or issues that may emerge. The BPAI director also told me that he sits on the Native Plant Board, and although he is not a botanist, he is able to ask critical questions to legislators about regulation that is not based on scientific research. In this sense, Mr. Brown sees his work on these committees as of support and not necessarily as places of political influence. Yet, as Paul Roth the DPI chief told me, some meetings organized by the USDA at the state and federal level also have representation of major growers who are able to weigh in program overviews and budgets, adding that this type of dialogue is becoming more common in the regulatory process. 
Many of these associations have well-structured hierarchies and positions which operators use to meet other people in the trade and to serve in positions of decisionmaking. Roger Smith, a fernery owner in the northern region of the state, told me about how impressive the FNGLA's political system was. As he described it the FNGLA and its chapters require local chapter presidents, local boards of directors, and other positions that are rotating and which ensure that a large group of people are involved in the functioning and decision-making of the organization. Similarly, other operators participate in a variety of plant boards that range from state to federal in function, and which represent a variety of commodities and regulatory practices. As one owner told me, "I'm involved in the national Landscape Germ Plasm committee. The federal government's got like 12 committees for different agricultural commodities. I'm on one of them and I stay abreast of the situation." Another operator told me that he sits on the board of the Farm Bureau because "that helps set policy for ornamental horticulture. Uh, I know they work on it every year to, for different concerns that the industry has, and they meet with the people from the different regulatory agencies within the state to try to help."

Another way in which industry actors are able extend their networks is through links with university researchers and students. The APHIS director explained to me that in conjunction with University of Florida and Florida A\&M Professors, many students and graduates are able to intern or work for the regulatory agencies, specifically in areas of science, regulation, and pest awareness. Mr. Miller also sits on a board of advisors created to mentor students, and while he acknowledge the importance of such practices that respond to industry needs, he does acknowledge the danger of stretching too thinly through a variety of extra official activities. When I followed up with Mr. Miller regarding the dangers of too much cooperation with other industry stakeholders, he explained that 
although contact with private interests was not necessarily influential at his agency, he did have a lot of personal contact with other industry actors and he could see how their lobbying of politicians and elected officials often starts subsequent dialogues at the USDA level of policy making.

This strongly woven network helps to keep a well-connected group of individuals of the plant nursery industry informed of any policy changes taking place in the industry. The network allows for fast and unified responses to any type of regulation being imposed from above or from other U.S. states and which may adversely affect the economic goals of Florida nursery industry elites. This process, according to industry elites is inclusive and democratic, especially since according to several of them, allows for an open and transparent system of professional opinions, science, and business practices that make sense for the health of the industry. Certainly, for industry insiders this model of consensus building and autonomous regulation seems inclusive and democratic, but it clearly links individuals from business, science, and politics fairly close to one another and facilitating those bonds of dependency through a well-established regulatory regime.

\section{Neoliberal Winds: Inconsistency and Opportunism}

From a theoretical perspective, elite actors within the plant nursery industry do represent traditional views about neoliberalism as an ethic through which the social good can be maximized by liberating the flow of goods, services, and capital from government regulation. Persistent in the discourses of Florida plan nursery operators is the idea the federal government is unfriendly to the interests of business practices, as Neil Simon, a north Florida Fern grower put it, "government has not been our friend." Other elite players were more specific in condemning the federal government's handling of labor, trade, and migratory policies and often employed the analogy of the government 
"breathing down people's necks" as way of describing what they consider excessive government intrusion in their professional practices. In addition, and in tune with a variety neoliberal scholars (see MacEwan 1999, Harvey 2005, and Shaikh 2005), the values and discourses of industry elites are often adjusted to achieve ends that are contradictory to neoliberal foundations and which have clear implications to the restructuring of a variety of social structures.

Such contradictions are obvious in a variety of discourses as well as in specific regulatory policies on which industry elites must rely to survive economically. Take for instance, quarantine 37 which is known to all industry elites as the most powerful mechanism protecting the environmental and economic interests of nursery producing states. The policy requires a large contingency of researchers, regulators, field investigators and code enforcers which must work together through a variety of federal and state agencies to control the dissemination of pests and invasive plants and in a very direct way protect the economic health of the industry. Although industry professionals from my sample were eager to defend its merits and often touted the economic support given to political candidates and the lobbying body, they never condemned the use of economic resources required by the federal government to enforce the policy at ports of entry and farms or in research and scientific regulation. When they did complain, they often did so because they thought that DHS is not necessarily qualified to do such job, but not because the federal government was using too many resources or too much power in its enforcement. This pattern of inconsistent application is also visible in the justification of the FNGLA's CEO for seeking federal aid in the 2007 drafting of the Farm Bill. In his statement, Mr. Sadek claimed that he was not seeking special entitlements, but rather supporting the Bush administration's proposal to 
invest $\$ 1$ billion in research of nursery crops, as well as a participation in a couple of risk management programs.

Another area of contradiction between theoretical and practical implications can be seen in the close relationship that exists between industry professionals and the state regulatory agencies of the federal government. From my interviews with the industry elites, it was clear that these actors see themselves as players on the same side of issues that affect business and industry. Mr. Sadek explained that "the Florida Department of Agriculture has an outstanding track record and a reputation of working with the industry. And they have a good sense of the challenges that the growers have." Similarly, Paul Roth, the states DPI director told me that the relationship between regulators and business elites is not an adversarial, but rather "a cordial relationship where we try to help them stay in business" and added that the regulators see the business elites as stakeholders or customers, and as such, "try to enhance their business, not tell them what they can't do." Similarly, during a conversation about regulatory practices in the industry, Jeff Brown, the BPAI chief told me that regulators "are here to help them, and most regulations help them. We help the industry bill, ship and move the product"

This trend is consistent with the perspectives of neoliberal scholars who argue that, to be pragmatic, neoliberal policymakers have had to shift from theoretical foundations toward an application characterized by inconsistency and opportunism (Clarcke 2005). In the Florida plant nursery industry the values of regulation expressed by industry elites are negotiated and applied in rather ambiguous ways. For one, nursery elite actors often condemn and reject government intervention, but know that it is precisely because of governmental enforcement of quarantine 37 that they can remain successful in the U.S. since the law prohibits any import of nursery material and outright prevents international 
competition in plant nursery production. In addition, while many industry elites defend a system of policy and regulation that is inclusive to all actors within the industry, they tend to deny the degree to which private interests affect the regulatory policies. The State's

DPI director's answer to one of my policy questions clearly exemplifies this issue,

If it's an enhancement to our plant protection laws at the state level, um, many times that comes to us from an industry group, we would like for you to, um this is a recent example, we'd like for you to have a law that says, the division of plant industry will have preemptive authority on where honeybee colonies can be located, so local governments can't ban honeybees in their jurisdiction. So we take that and develop it into a legislative proposal, and then work with a legislator to get it sponsored into a bill. But the first thing, if you get a legislator to sponsor a bill, the first thing he asks you is, who's for this? Who's against this? And then you have to get letters of support from the various stakeholders and feed them to that member of the legislature to show that he's not, um, stepping into something that would be political suicide.

What ends up happening in the plant nursery industry, thus, is a deregulation of the regulatory bodies instead of the ideal non-governmental deregulation to which elite actors (claim to) aspire. In other words, the level of decision-making takes place on a deregulated and semi-privatized environment in which business representatives are able to manipulate the political process by freely navigating through the scientific and political arenas. This is done openly and labeled transparent since it is not taking place behind closed doors. But in agreement with the formulations of Rapley (2004) and other globalization scholars, a regime has succeeded in consolidating a position of power and accumulation through the establishment of distributional networks, in which both the political and economic elites are related in mutual bonds of dependency that allows them a high degree of political leverage and the ability to exclude the masses from the political process.

\section{Conclusion}

I began this chapter with a preliminary discussion of the beliefs and values of Florida plant nursery employers in regards to regulation in four critical areas. Specifically I 
discussed how employers in the industry regard regulation in terms of labor migration, competition from unregistered or uninsured farms, agricultural trade, and the scientific justifications attributed to this last one. I used this preliminary analysis to highlight the way in which policy implementation and regulation play a vital role on the discourses and practices of operators of the plant nursery industry and to contrast these values and practices about regulation with a variety of neoliberal tenets associated with economic reforms of the last three decades.

In many ways my findings in this area were not surprising and are well supported by the critiques of neoliberalism and globalization highlighted in chapter 2, particularly since the values of plant nursery operators about regulation tend to have ambiguities and contradictions which are not often perceived by those operators advocating for them. This was clearly seen as the overwhelming majority of operators with whom I spoke support heavy governmental regulation in areas of immigration, business competition and international trade, but seem to support a de-regulated environment for the creation of policy making in regards to the international competition and trade policy. These ideas were often spoken by operators who, at least ideologically, regard regulation as a mechanism of intrusion by the federal government in their everyday economic practices. However, when the conversation turned to real life practicalities, the operators had no problem asking the federal government for larger oversight and control.

These early discussions about regulation opened the road to deeper understanding of the question of why and how has plant nursery production in the state of Florida remained one of the most important sites of nursery plant production for the US market amidst neoliberal economic restructuring of the last three decades? Clearly, plant production in the state of Florida has not followed recent trends in commodity production, where multinational corporations have sought areas of production in the 
developing world where labor and environmental costs are cheaper. This is in great part the result of a combination of factors that include regulation as well as the collective efforts of plant nursery elites.

At first, it seemed clear to me that part of the success and permanence of the industry in the state could be attributed to SPS regulations imposed by the federal government and which prevent the import of nursery products from other areas of the world. In this sense, all of the elite members I interviewed saw SPS regulation as an essential requirement to protect Florida ecosystems from invasive plants, insects, and pests and only saw economic protectionism as an indirect benefit of the regulation. But something that became clear to me during my fieldwork was that SPS regulation did not come about free from intervention from elite actors who rally collectively to maintain and enforce the policy at the federal level. Industry elites are highly aware of the role that SPS regulations play on industry survival. As a result they spend invaluable resources on political lobbying, research, and control in order to maintain a strong body of regulation active through the legislative body.

In many ways, the overwhelming support for SPS regulation in the nursery industry is founded on a socially constructed ideology about the unknown effects and dangers that invasive plants and organisms could have on local ecosystems. Certainly, by arguing that the beliefs and ideas of industry elites regarding SPS regulation are socially constructed I do not mean that some of their fears are unfounded, but rather that in many ways the discourses and market-place behaviors of industry elites have been greatly influenced by the claims of powerful actors in the scientific and political communities, and thus have been widely accepted as ultimately true and immovable by a variety of industry operators and professionals. 
The socially constructed nature of the regulation ideology was made clear to me through many levels of the industry professional structure. In my interviews with scientists of the USDA the defense of a strong SPS regulation was consistently presented to me as a necessary protection to our state's ecology, but when I probed deeper, the scientists conceded that political lines do not adequately represent geographical areas or hardiness zones and most importantly that a large amount of invasive organisms make their way into our state through the millions of travelers and imports that come into the country through Miami on a yearly basis. Still, the scientists discourses were embed on the idea that science serves as the ultimate arbitrator and guide to determine the course of regulation and that it is their research which supports the policy both at the state and federal level and not political actors as many international trade analysts argue.

For industry professionals the science-based claims of regulators justify their own discourses about regulation and in turn use the claims to lobby political legislative bodies in support for strong protectionist measures. This is also true for operators, who organize together through the existing professional organizations in efforts to maintain their market position in a clear opposition to international competitors or national competitors who may seek to produce nursery plants abroad. In this sense, scientific claims become part of a strong and well-unified body of regulation that is supported by a widespread ideology and discourse of ecological and economic protection and which have real implications for the success and permanence of the industry in the U.S.

A second important factor in the permanence and success of the industry in the state of Florida lies in the interaction of industry and the strong social networks that they have managed to create. As my analysis of interviews demonstrates, lobbyists, trade representatives, organizational leaders, academic researchers, and many of the 
prominent operators of the industry have close working and personal relationships with one another and these connections often stretch to the regulators of the industry. These relationships are forged through a variety of committees, boards, and initiatives that bring a variety of actors together and which create the necessary conditions for them to work with one another. In this sense, the many boards and committees in which members of the plant nursery elite sit help to craft and reshape a variety of messages, discourses, and policies which effectively shape the course of the industry.

Lastly, as Berger and Piore (1979) argued, the role of the traditional industry should not be ignored when analyzing trends in new configurations of commodity production. As my analysis indicates, small traditional firms can create sufficient control to carve their own collective paths despite global trends that would suggest a very different market behavior. It is possible that this market behavior is driven by small businesses because low capital costs allow for a large conglomeration of small individually and family owned business to operate without the competition and constrains provided by large multinational corporations. As a result, plant nursery producers in the state of Florida have been able to overcome a significant organizational gap despite of the fierce competition that exists among producers and despite the fragmented nature of production itself, where a variety of products are produced under the umbrella of plant nursery production.

In many ways the success, permanence and durability of the plant nursery industry in the state of Florida can be attributed to a combination of factors embedded in the beliefs and interactions of industry elites and the de-regulatory policies that they have been able to institutionalize. First, because regulation is in great part driven by the ideologies of powerful actors within the industry and supported by the collective efforts of thousands of small and medium sized producers, it has become part of a greater 
collective effort to maintain a strong market presence, despite recent trends to outsource production in a variety of industrial sectors of the US. Second, the relationships among industry elites - including regulators, operators, and professional representatives allows for a very unified system of policy creation that is consistent with many of the neoliberal trends and theories of recent decades. In this sense trade regulation is the result of a de-regulation in the process of policy making as decisions are made in an overt agreement between the industry insiders and later proposed and lobbied to the appropriate legislative bodies at the state and federal level. 


\section{PLANT NURSERY WORK IN FLORIDA: LIFE IN THE MARGINS}

On a warm Florida night, Edilberto and Juan, two Maya-speaking Florida farm workers, attended a workers' rights forum hosted by WeCount!, an immigrant social justice organization in the municipality of Homestead in South Florida. The farm workers hoped that the organization would help them recuperate unpaid wages owed to them by their previous employer. In halting Spanish, the indigenous Guatemalan workers explained that several months before, their bosses started to fall behind in paying salaries, giving the workers only part of their weekly wages under the promise to pay in full the following week. However, these promises failed to materialize and in a matter of months the workers were owed several weeks of pay. For some time the men remained patient, but the situation intensified when the workers, pressured to send money back home and falling behind in their rent payments, complained about their back wages. The immigrant workers were fired; their employers threatened to call immigration authorities if they showed up again or took any further action to get paid. Stories like that of Juan and Edilberto abound in Florida's Farm nursery industry. In fact, it was these kinds of stories that led me to do research in this industry that has received little attention from social scientists in the United States, except for a variety of economic studies and analyses. $^{20}$

Until now, I have focused this manuscript on a variety of theoretical prescriptions about globalization which propose that within the larger neoliberal frameworks of the last three decades, industrial production has tended to move to peripheral areas in the developing world in search of deregulation, efficiency and lower production costs. However, as I demonstrated in Chapter 2, resistance and shifts within specific industrial

${ }^{20}$ The Institute of Food and Agricultural Sciences (IFAS) at the University of Florida (UF) has close links to a variety of agricultural sectors in the State of Florida. They do research for Florida's agricultural industries and produce economic impact reports to a variety of industry sectors in the state (http://ifas.ufl.edu). 
sectors of the developed world can also correspond to a series of arrangements that are forged and enforced by regimes of economic and political elites who can exert sufficient power in policymaking to create discontinuous spaces in current modes of globalization. What this means for plant nursery production in the state of Florida is that while a variety of powerful actors have been greatly successful at resisting global trends by keeping nursery plant production localized, they have come to rely on a large supply of foreignborn and low-wage workers in order to remain competitive in an increasingly global and deregulated marketplace. But what exactly are the implications for the large, immigrant labor force of the plant nursery industry in terms of working conditions, rights, and benefits? And how are labor-migration trends in the plant nursery industry consistent with current theories of globalization?

As several scholars of immigration and labor migration contend, there is a logical fit between the labor needs of US employers and the presence of undocumented workers in the country, which reveals a deliberate political manipulation to supply important sectors of the employer class with a supply of cheap labor, specifically in occupations characterized by shift work, hazardous conditions, and job insecurity (Sassen 1988, Portes and Walton 1981). These workers are particularly desirable to employers because they are seen as diligent and motivated employees, yet are compliant and readily accept positions with low wages and no benefits (cite BBD). Such workers are found in a wide range of economic activities including agriculture, manufacturing, and in a variety of service occupations (Portes and Rumbaut 2006); among these is Florida's plant nursery industry.

The gravitation of labor migrants toward labor-intensive industries that offer low wages and no benefits has been explained within the context of a segmented labor market, where particular types of jobs are associated with distinctive types of workers 
(Piore 1979; Wldinger 2003). Those jobs at the "bottom" end of the segmented market tend to be labor intensive and are often occupied by immigrants or women based on racialization and arbitrary conceptualizations of who is "best" fit for a type of Job (Waldinger 2003). This division of the labor market is said to create ideal conditions for an immigrant labor force entrenched in the production of dead-end jobs and precluded from accessing jobs in high end sectors, while also institutionalizing two classes of workers (Mahler 1995). This segmentation is also paradoxical since it continues to allocate labor migrants to those marginal sectors of the economy despite increases in unemployment and de-industrialization in the developed world. This de-industrialization came accompanied by increased levels of overseas outsourcing, and a measurable loss of middle income jobs in manufacture in the United States (Sassen 1990; Mahler 1995; Portes and Rumbaut 2006; Shelley 2007). But in plant nursery production, where outsourcing production is not allowed by governmental regulation, the allocation of workers to the low end of the labor market too often seems like the most clear and acceptable condition for market players.

In this chapter I consider compelling forms of exclusion, exploitation and marginalization of the immigrant labor force of the Florida plant nursery industry, focusing on the complex interaction of structural processes associated with the workers' process of social and economic incorporation, from their migratory status, and from some of the institutional arrangements forged within the plant nursery industry in the state of Florida. Specifically, I contend that workers of the Florida plant nursery industry find themselves entrenched in a variety of institutional disadvantages that emerge from (1) an uneven system of economic and emotional investments that migrant workers must make and which are associated with their migration and settlement into the state's plant nursery industry, and; (2) labor vulnerabilities associated with wages, benefits, and 
working conditions that arise from their immigration status and from a series of institutional labor practices that often produce constant fear of firing, detention and deportation. I begin my analysis with a description of the journey that workers must make to find work there. In addition I provide an in-depth look at the characteristics of nursery farm workers within my sample to make a more compelling argument about their living and working conditions.

\section{Characteristics of Plant Nursery Workers}

The plant nursery industry in Florida relies heavily on labor intensive work from a predominantly immigrant work force. This was clear from my early research in MiamiDade County and then later ratified through my observations and discussions with industry entrepreneurs and organizers throughout the state. I was also able to establish that an overwhelming majority of nursery work in Florida is performed by immigrants from rural areas of Mexico; however, in the state of Florida, and particularly in its southern regions, a large number of indigenous Guatemalan immigrants have become the predominant group of workers in plant nursery production. Unfortunately, there are no numbers to account for the ethnicity, gender and longevity of workers in the nursery industry, and although the National Agricultural Worker Survey (NAWS) does provide some demographic estimates of the national farm worker population, it does not distinguish between the kinds of agricultural work performed by the workers or the specific states were they reside and work.

According to the NAWS, 78 percent of the agricultural workforce in the U.S is foreign born, with about 75 percent coming from Mexico and two percent from other Central American nations. The NAWS also report that about 53 percent of the foreign born agricultural workers are in the country without legal work authorization, while 21 percent are legal residents and about 25 percent are legal U.S. citizens. Figures 1 and 2 show 
the place of birth of the agricultural labor force and the employment eligibility the foreign born in the U.S. In the State of Florida's plant nursery industry, However, one thing that has become clear in recent years, due to an increase in ethnographic work related to Maya migration is the fact that large Guatemalan communities have been established in the Florida rural areas of Indiantown, Homestead, Immokalee, and Okeechobee (see Burns 1993).

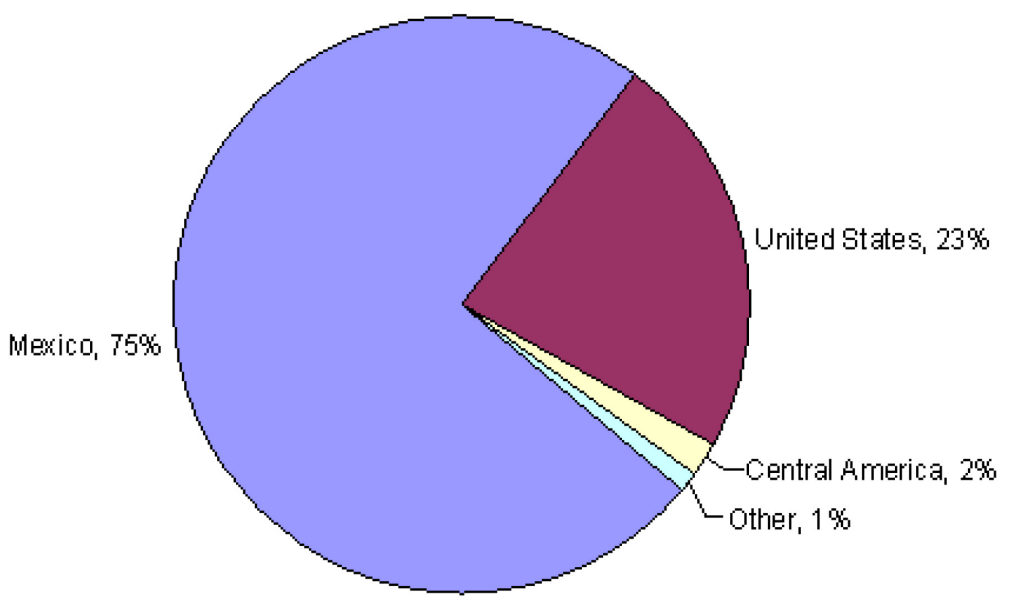

Figure 8. Place of birth of the U.S. agricultural workforce (USDOL-NAWS 2012)

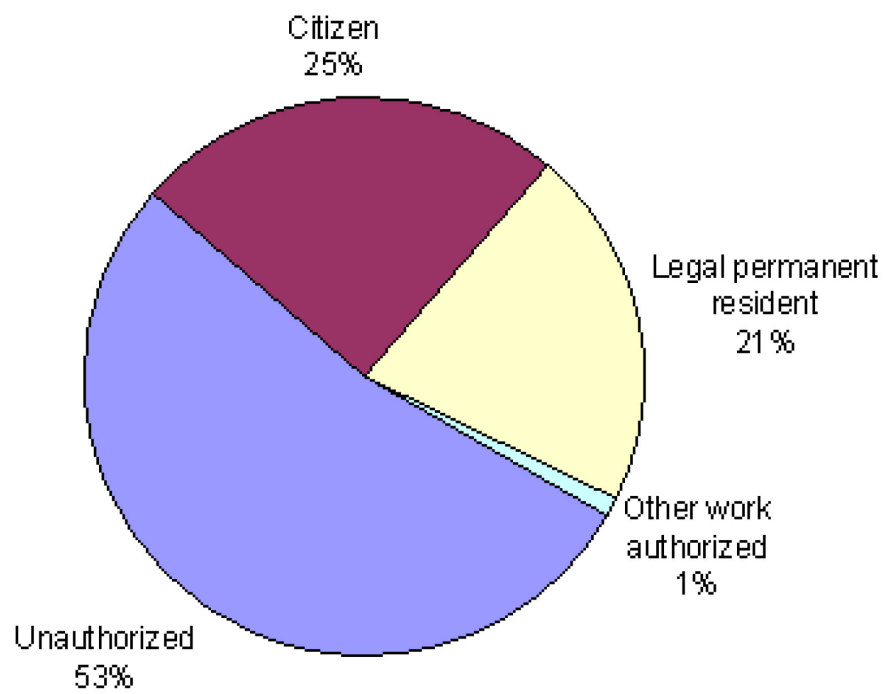

Figure 9. U.S. Employment eligibility of the foreign born agricultural population (USDOL-NAWS 2012) 
My own field work with the workers of the plant nursery industry focused on the southern areas of Homestead and Florida City and to some extent reflects the previously noted demographic characteristics. My sample of workers consisted of 40 face-to-face, in-depth, open-ended interviews which were conducted between 2007 and 2009. Of these workers 25 had come from the Guatemalan highlands northwest of the country's capital, while 11 Mexican, three El Salvadorian, and two Haitian immigrants completed the sample. The median age of the group was 37, with ages ranging from 20 to 58 years. The median number of years in the country was eight and ranged from just a few months to 36 years in the country. In terms of gender, the sample contained 29 males and 11 females (see table 1). It is important to note that only a handful of those interviewed resided legally in the US at the time of the interviews, while the majority of those workers in my sample were undocumented and possessed no legal permit to stay or work in the country. This was also made clear through my interviews with industry elites and community organizers, but knowing the real extent of undocumented workers in the industry is difficult to assess because to this writers knowledge there is no census or reports on the workers of the plant nursery industry. Map 1, shows the sending areas of the workers interviewed during my fieldwork.

Table 4. Characteristics of Plant Nursery Worker in Sample

\begin{tabular}{cccccc}
$\begin{array}{c}\text { Country of } \\
\text { Birth }\end{array}$ & Male(N) & Female(N) & $\begin{array}{c}\text { Median } \\
\text { Age }\end{array}$ & $\begin{array}{c}\text { Years in the } \\
\text { US(Median) }\end{array}$ & $\begin{array}{c}\text { Authorized } \\
\text { to work(N) }\end{array}$ \\
\hline Guatemala & 21 & 4 & 37 & 2 & 1 \\
\hline Mexico & 5 & 6 & 41 & 17 & 1 \\
\hline El Salvador & 2 & 0 & 42 & 15 & 0 \\
\hline Haiti & 1 & 1 & 40 & 14 & 2 \\
\hline $\begin{array}{c}\text { Column } \\
\text { Totals }\end{array}$ & 29 & 11 & 37 & 8 & 4 \\
\hline
\end{tabular}


Map1. Sending Areas of South Florida Plant Nursery workers interviewed

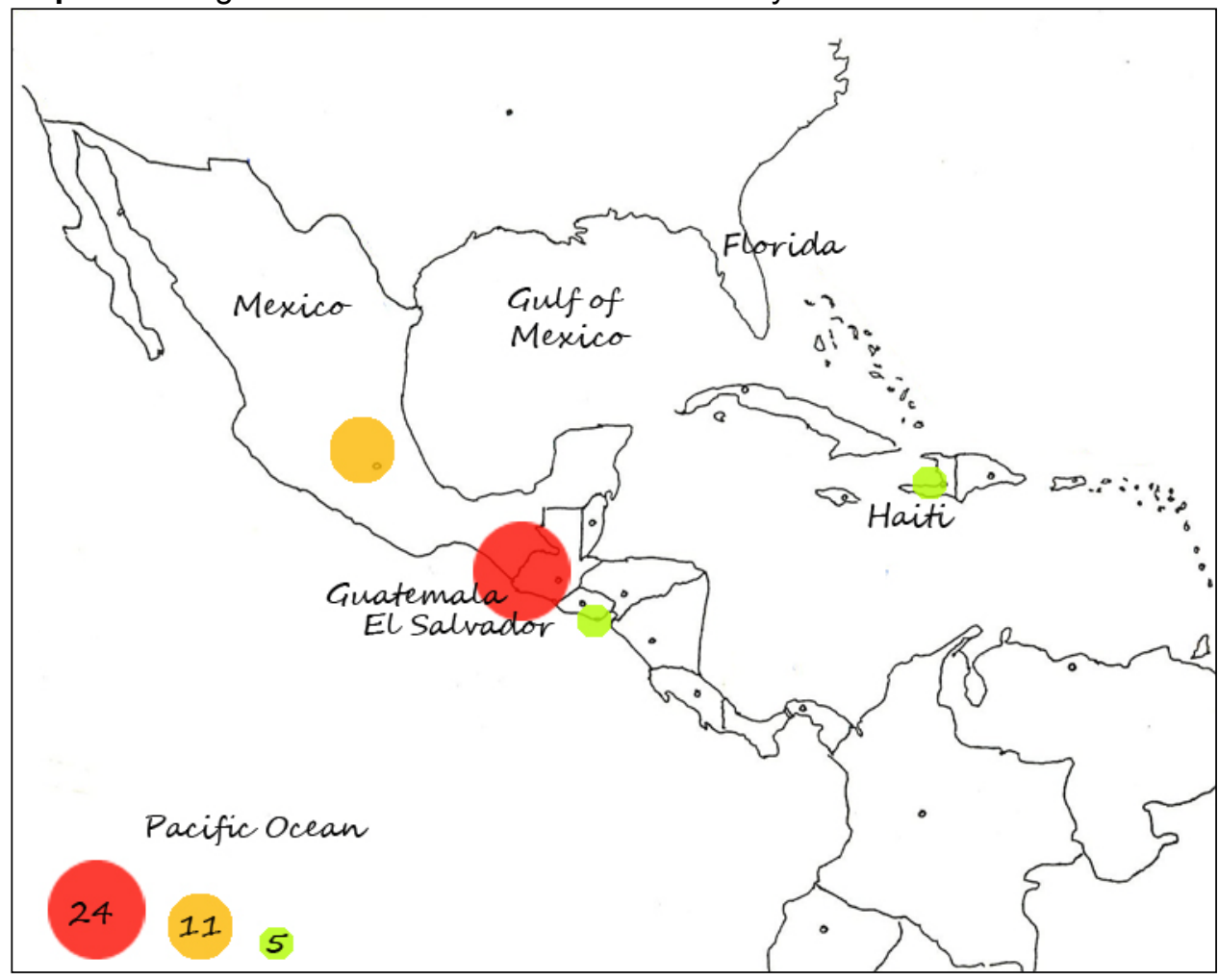

\section{Camino al Norte; Uneven Investments and Returns}

Before arriving to the state of Florida and working in the plant nursery industry, many industry workers are required to embark on a long and risky journey through parts of Central and North America. Many of these risks are associated with unscrupulous smugglers and law enforcement officials along the journey, while others are the result of dangerous geographical conditions that must be tackled and include river and dessert crossings or dark boat rides in the middle of the night (see for example Mahler 1995, Ramos 2005). Once settled, many of the migrants find jobs in low wage industries such as the plant nursery industry, which is highly dependent on low-wage immigrant workers and on a continuous supply of workers to sustain their operations, thus relying on an informal, yet well-established system of recruiting where investments and expenses fall 
almost exclusively on the workers (see Cameron, Lippard and Gallagher 2010). These are important aspects of the institutional arrangements that shape plant production in the state of Florida. In this section I describe how some of these uneven risks, difficulties and investments are visible in the State's plant nursery industry and what some of the consequences are for the workers, their employers and their communities.

From the beginning of my sample collection, I made it a point to collect workers' information about their journey and about how they ended up working in the plant nursery industry. At first, this was important to me because at a personal level I believe that these stories are rich expressions of the inequalities that our current global economic systems reproduce, but at the same time because they are examples of the dedication and tenacity of human beings looking for opportunities in what seems to be a highly unequal world. I later understood that these stories also demonstrate those structural and institutional implications that affect relations and conditions in the sending and receiving towns as well as on the industries that receive low wage workers from the developing world. In this section I use that data collected from the workers regarding their journey and I supplement some of those structural and institutional implications from my own field observations and from conversations with a variety of actors of the plant nursery industry and of the organizing community.

\section{Making the Journey}

Most of the workers I interviewed fit within the ethnographic record detailing the journey that rural workers from Central America must often make when traveling northbound to the United States (see Portes and Rumbaut 2006). Their journeys through Mexico, particularly for those who come from Guatemala and El Salvador, are filled with vivid descriptions of hunger, fear, abuse from smugglers and police, and the bittersweet sensation of making the journey safely while being separated from their 
families and friends. This is what Cristina, a 27 year old female from Guatemala told me about the dangers and risks associated with her journey:

About 22 people started the journey in Guatemala; they [the smugglers] put us all on a boat, so we were crossing from Guatemala to Mexico. We traveled all day, until about one in the morning. We arrived in a place called Huatulco and they said "we're here." So I jumped but I couldn't reach the bottom. I know how to swim a little, but there were some that could not and they never made it. Out of the 22 people who started, only 15 of us made it. Once I reached the shore I started running, but then a police patrol arrived and we had to pay them 500 pesos to take us somewhere else. They took us to Queretaro. The coyote then bought us a bus ticket to Matamoros from where we had to walk for 8 hours to get to Houston. From there, they sent me the money that I needed to pay off the coyote. It took me three more days from there to Homestead where my mom was waiting for me.

Fermin, a worker from Michoacán also described the risks and dangers of his trip from Mexico as a journey filled with unknown dangers. As he explained, "I came from Michoacan to Miguel Aleman, where I contacted a coyote who crossed us across the river at night and then a walk across the dessert for about two days. We ran out of water after day one, and then we had to drink water from a pig sty in a ranch we found along the way. We arrived to a town where other coyotes where expecting us, completely dehydrated with blisters on our feet and with very bad sunburns." In that journey, Fermin told me that of the 20 people who embarked on his journey through northern Mexico on his way to the U.S. several were arrested and deported while others were separated from the group. He was able to avoid the Mexican authorities, and contact his coyotes to smuggle him across the border.

Another Guatemalan worker, named Luis described his journey as the result of the violence that his country was experiencing in the last decades of the $20^{\text {th }}$ century. As he explained, "I was never persecuted, but finding work was becoming harder and harder." At the time when I met Luis, he had already been in the country for close to fifteen years. He was a short Mayan man with large and rough hands. Although never formally educated, he was well-trained in advanced agricultural skills such as working with heavy 
industrial and farm-related machinery such as tractors, drills, forklifts, and saws, which gave him an advantage when seeking work in the plant nursery industry of the State. Luis' journey carried heavy emotional and economic expenses for which he had to make alternative decisions to travel. In sharp contrast to the experience of other workers with whom I spoke, Luis' trip to south Florida was long and particularly tedious. As he told me, he left Guatemala with three friends on a bus trip through Mexico. Since they had little money and no property to get a loan in Guatemala, they planned to work at plantations and farms along the way in order to make money for the each leg of the trip. Once in the U.S.-Mexico border region, Luis and his friends worked extensively for over a month cutting chile and cotton; "once there we met other people who were waiting to cross [the border], we made friends and then some people that had already crossed and knew the terrain and asked us to go with them." In that journey, Luis met some people that offered him a ride to Indiantown, Florida in return for payment once he got a job. He accepted and ended up in South Florida without friends or pre-established support networks to help him along the way. His journey to Indiantown lasted more than three months.

\section{$\underline{\text { Investments and Returns }}$}

The emotional and economic investments made by the immigrant workers of the Florida plant nursery industry are consistent with recent modes of globalized production where employers externalize costs to the labor force by transferring environmental and health costs to the workers (see Greider 1997; Harvey 2005). In the case of Florida plant nursery employment, the workers assume $100 \%$ of the transportation, recruitment, resettling costs, and health costs in addition to those hard to measure emotional and psychological investments that they must also make. Many of the stories that the workers shared with me are emblematic of the experiences of thousands of agricultural 
workers who often risk their lives in order to secure what they see as a better opportunity for themselves and their families.

Many of the individuals who shared their stories with me contend that they had to leave their spouses and children behind in order to secure a better future for them. As Ricardo, a Guatemalan worker from Quiche and father of four in his native country explained, he sends a considerable portion of his salary back home for his children's education and to invest on a small lot to build a home. His decision to come to the U.S. was according to him "a family decision because in Guatemala there were no jobs to pay for his kids' education." He had to borrow some money from friends and family to secure US $\$ 4,500$ for the trip through Mexico. Ricardo had not seen his family in over 5 years while working in the State of Florida. He told me that he would like to return home, but that he had no clear plan or idea of when he would be returning.

Similarly, Francisco, A 46 year old Mexican worker who at the time of my field work had been in the country for 6 years described his journey as stemming from a desire to bring economic stability to his wife and children. Francisco told me that he did not want to stay in the U.S. for a long period of time, but fears for his children's security and stability. He expressed a deep concern for his children's development and describes his move to the U.S. as a sacrifice so that his children "do not have to go through the things that I have had to experience." He told me that, he wants his children to do better than him, and that despite living in the U.S. in tight economic conditions there is always more opportunity to help them.

In the case of plant nursery production in Florida, the recruitment process is quite informal since there are no government visa programs or private companies which do recruitment for plant nurseries abroad, as it is often the case in other forms of 
agricultural work such as foresting and food agriculture. As the FNGLA CEO explained to me,

There are some other segments of agriculture, vegetable growers I guess, that do use the $\mathrm{H} 2 \mathrm{~A}$ program. Very few, if any, in Florida nurseries use $\mathrm{H} 2 \mathrm{~A}$. There are some in other parts of the country, some nursery growers I know in the Midwest and some in the Northwest. But, you know, my experience in talking with growers who have either considered it, or in other parts of the country who have used it, $\mathrm{H} 2 \mathrm{~A}$ is very expensive, more, you got to pay for housing. You have to construct housing is what it is. But most importantly, what happens as soon as an operation uses H2A, it becomes a magnet for all these legal service harassment. So most, a lot of growers will stay away from it.

As a result, industry employers rely on their workers through word of mouth to bring friends and relatives to work for them during times expansion or peak seasons. This scenario means that workers must invest heavily on their mobilization to Florida and their settlement while they find a job; a process that fits well within the literature and theoretical arguments which postulate that U.S. employers benefit largely from an unregulated and substantial low wage labor force to secure an endless supply of cheap and flexible labor (Portes and Rumbaut 2006).

From my interviews and observations I was able to corroborate that the workers rely on an unofficial, yet well-established system of recruitment that largely benefits industry employers. As I explained through the FNGLA's CEO comments above, there is no guest worker or recruitment system in the State of Florida, and the employers simply put a word out to their workers when they need extra hands at the farms. This was consistent throughout my time on the field as all of the employers I interviewed readily accept the system and rarely rely on picking workers up from corners, worker centers or placing ads in order to select their workforce. As one south Florida operator explained to me, placing ads or recruiting from a corner where workers stand waiting for jobs "has proven very unreliable and since you are never certain what kind of worker you are 
going to get." Instead, having a worker recommend a family member, friend, or acquaintance reduces the amount of uncertainty about that worker's qualities.

The same was true for the workers I met during my field work. Although some of the workers journeyed to the U.S. haphazardly, that is not knowing where exactly they were going and relying on other migrant workers whom they met on the road for information and advice on where to go, the majority came to the state of Florida and to its plant nursery industry with the complicit economic and moral support of an already established friend of family member. Juan a Guatemalan worker from the region of Quiche explained that he had helped his brother and two cousins make the journey after having settled in the state and the industry by helping them raise the money for the trip, giving them housing upon their arrival, and recommending them from jobs in the area.

There is no way to calculate the non-material investments that these workers have had to make in order to get a job in the plant nursery industry. Such adverse conditions for the workers continue to mount as they settle into their new communities, where they often live their lives in social and political marginality and where the pressures to send money back home have a strong effect in the types of jobs and wages they are willing to accept. In addition, as I will discuss on the Working conditions and Vulnerabilities section later in this chapter, the workers must also carry the costs of healthcare and often deal with a series irregularities associated to wages and other forms of harassment and abuse. These conditions are all part of a system where the employers externalize a significant amount of the costs associated with their labor force to their workers and where the benefits received by the workers rarely match the economic and emotional investments that they must make. 


\section{Expectations to Assimilate and the Myth of Stable Communities}

During my fieldwork, part of my focus also concentrated on the community life and incorporation of the workers to some of the social structures at their new home. To this end, I often inquired of workers, employers and community organizers about the life in those cities and towns where the workers had settled. Part of my interest emerged from what I first perceived as a clear difference between the "settling" experiences of nursery workers versus those of other agricultural migrant workers who live -sometimes temporarily - in more rural geographical areas. As the leading member of the state Florida Nursery Growers and Landscapers Association (FNGLA) explained,

Throughout the State, nurseries are mostly close to urban areas. If you took a map of Florida and said, "Alright, here are the ten biggest cities in Florida" and then took a map and overlaid it with "here are the big nursery crop production concentrations," they'd be right around all those big cities, whereas a lot of other types of agriculture are really rural. But nursery is very much, almost urban agriculture. It's much closer to the markets they serve.

I tested FNGLA leader's hypothesis about the urban nature of nursery agriculture by overlaying the largest centers of plant nursery production with the highest urban concentrations in the state in a map of Florida. As Map 2 demonstrates, there is a high concentration of nursery production sites around important urban centers in the state. I also confirmed this notion during my fieldwork, as most of those nursery production sites that I visited were usually located in the outskirts of cities such as Miami, West Palm Beach, Orlando, and Tampa.

This geographical distribution has important ramifications for the settling and incorporation patterns of those immigrants that work in the plant nursery industry. Specifically as a north Florida nursery operator explained, this helps to "create more stable communities around those important centers of production in the state." The distinction that this employer makes stresses the availability of work in nursery versus 
that of other types of agricultural crops that are seasonal and which require the workers to move during the year in search of other sources of seasonal work.

Map 2. Florida's Top Five Nursery Production Sites by Urban Concentration

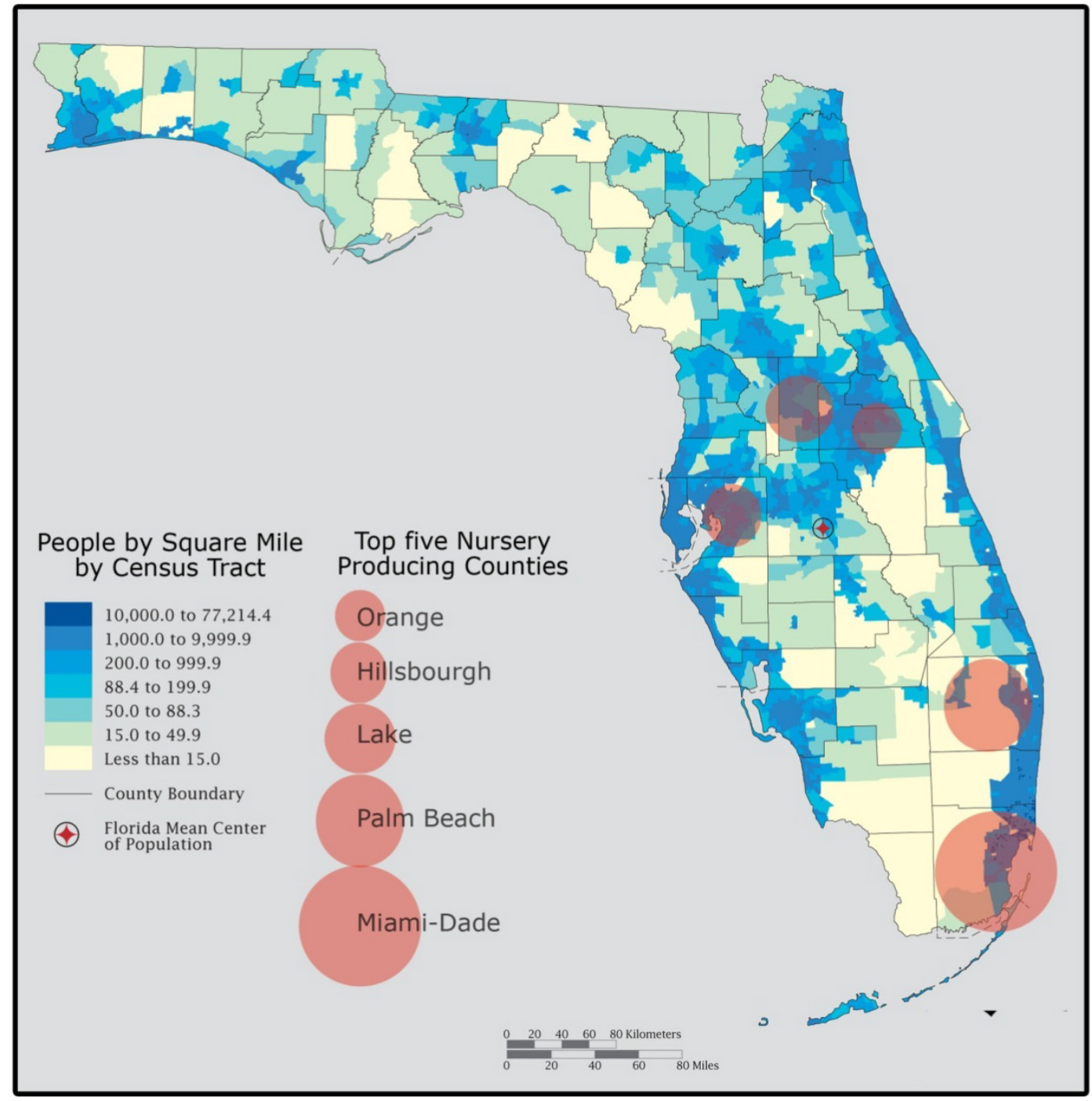

In the minds of these and other employers with whom I spoke, plant nursery production has created stable communities in those geographic areas of the state where production is taking place. To support this notion, Mike Smith, a large fernery operator near Daytona Beach drove me to a housing development a few miles away from his 
operation. The development, as he explained was the result of some public and private funding provided to build and manage housing for low income farm workers in the area. Unlike many of the many public "housing camps" that I visited throughout the state, this one was particularly well maintained, with the exteriors of the houses and the grasses and gardens around them groomed to excellent conditions. The operator then introduced me to Fermin, the premises' manager, a 40 year old Mexican immigrant who had worked for him since arriving to the US in 1993, and who now runs the housing facility with his wife.

The discourse of plant nursery elites regarding the stability of communities around the plant nursery industry often focused on the notion that that such communities could work to serve as places for assimilation of the immigrant labor force. For the North Florida operator involved in the housing camp in his community, the success of the housing camp and the "assimilation" of Fermin, the camp's manager who spoke English at all times demonstrated the success that the plant nursery industry could have on the lives of the immigrants that work in it. He was proud to point out that Fermin and his wife learned English and as a result had been able to grow out of the tediousness of nursery work, while remaining productive and stable members of the community. This case is particularly representative of the expectations that many industry employers have regarding the assimilation of the labor force. One Homestead operator told me that he thought it was necessary "to teach immigrant workers how to behave in public" and according to the standards of the US, and used examples of how throwing trash on the ground or drinking in public were behaviors that should be curtailed among the immigrant workers. This latter point was also made by a local police officer who seemed angry about sporadic displays of public drunkenness by nursery workers in the area. Another employer emphasized his dedication to the assimilation of the workers that he 
took on the responsibility of paying for English classes for his employees at the local community college.

Regarding these expectations, it often seemed to me that the entrepreneurs used these discourses of work ethic and assimilation as an excuse not to provide better wages or benefits to their workers, under the premise that those benefits would be eventually achieved by those workers who performed above the rest and moved up the socioeconomic latter. Unfortunately, the overwhelming majority of workers that I interviewed spoke no English and as result, proving the relationship between language acquisition social mobility would be difficult with my available data. However, whenever I saw some form of improvement for those workers who were deemed trustworthy or who stood among the rest, as in the case of Fermin, the benefits came at the hand of a closer relationship among the parties. In the case of Fermin and his family, such benefits were transformed in an opportunity to work outside the heat and strenuous physical conditions of the plant nursery fields, an added status as a manager of the housing facility, and better wages.

As I began my field work in the summer of 2007 , the U.S. was entering into a deep economic recession that severely affected many industries around the country. The plant nursery industry in Florida was no exception as many of the companies and workers were strongly feeling its effects. The plant nursery industry is highly dependent on construction because a large percentage of its production is destined for landscaping of new homes and roads. In addition, the recession resulted in decreased household consumption, including the home beautification projects that boost plant nursery sales at garden centers and improvement chains. The effects of the recession on plant nursery workers became obvious as I observed an exodus of people away from those communities that plant nursery entrepreneurs regarded as stable products of the plant 
nursery industry. During this time, I visited several apartment buildings that seemed eerily ghostly, with "for rent" signs in the majority of the windows. To me this had important significance because in many ways it demonstrated that these communities where at best "semi-stable" and depended greatly on the health of the economy and the industry for their stability. This was specifically harsh for these immigrant communities, since the mostly undocumented immigrant workers have no benefits of unemployment and are not protected against market fluctuations in the same way that native workers can be.

The expectations to "assimilate" and to settle into what industry elites perceive to be stable communities also provides other unintended layers of adversities for those immigrant workers of the plant nursery industry. As I mentioned earlier in this section, many of the nursery operators whom I interviewed have strong expectations for their workers to "assimilate" to American cultural values and often cited things like developing a strong work ethic, learning English, and behaving "properly" in public as ways to accomplish this process of "assimilation." However, with few exceptions, most of the operators I interviewed did not actively participate in the social or cultural incorporation process of their workers and only the operator who enrolled his workers in English courses and the North Florida grower who helped finance the housing camp seemed to invest on their expectations about their workers' "assimilation."

It is my impression, however, that in many other ways, those cultural expectations of employers toward their immigrant workforce resulted in very uneven investments and returns on the part of the workers, whose behavior is constantly scrutinized and evaluated in rather ethnocentric and demeaning ways by their employees. This scrutiny is often used as justification not to provide certain benefits and to penalize their workers for certain behaviors. During a long conversation with an operator in which the 
discussion of why no one in the industry pays health benefits to workers on the fields, he contended "they have to learn to work and to achieve their success through hard work." According to this owner, nobody gave him anything for free and if the workers want to achieve the American dream then, they too must prove themselves worthy through hard work.

\section{Worker Conditions and Vulnerabilities}

The behavioral expectations that industry employers place on their workers were also accompanied by a variety of institutional practices and beliefs that often had the opposite effect of the desired "assimilation" and community stability of immigrant workers. Many of these practices were embedded in the social and labor interactions of workers and employers and often facilitate the marginalization of industry workers, both inside and outside their places of employment and spilling into their personal and communal life. In this sense, working at or below minimum wages, experiencing wage theft, having no health benefits, absence of unions and a state labor department, and other adverse conditions have helped to create an underclass of voiceless and powerless workers. In this section I look at some of these common practices by nursery employers and their effects on the immigrant labor force, returning later to how these practices create marginal spaces for individuals and communities that provide the labor for the industry.

While I conducted my interviews, the majority of workers reported not knowing what the minimum wage was in the State of Florida. At the time of this research, the state's hourly minimum wage was $\$ 6.67$. A good example of this lack of information is shown by Mario, a nursery worker who has been living in Florida since 1992. When asked if he knew what the minimum wage in the state was, he told me, "I think it is around six, six something I believe." Similarly, Marta from Puerto Rico stated, "The truth is I do not 
know, I do not think anyone at work would provide me with this (information) and there are no posters or information available to us." For Miguel who had been a victim of wage theft on two distinct occasions, the answer was similar, "I do not know. I've never been given such information."

One common form of wage theft in the south Florida nursery industry is failure to pay minimum wage. As Jose from Mexico explained, “I left my previous nursery job two weeks ago; they were paying me just $\$ 6.40$." Jose was one of a few workers who actually knew what the newly legislated state minimum wage was $\$ 6.67$ at the time. I asked Jose how he had gotten this information. He said "[We] always listen to the news, but we are not really sure if that is true. So I told my boss to pay us at least the minimum (wage), but he said 'no.' He told us his company was struggling. After that, he started to get mad at me; he changed with me and did not even want to talk to me." Having complained about his sub-standard hourly rate, Jose was forced to leave his job because of the harassment he received from his employer.

Similarly, Teofilo, another plant nursery worker from Guatemala, explained the way in which wage theft occurred at his work place.

At a nursery in which I worked before, they would take away our hours. We would complain and we would still not get paid. There, the foreman would write down the hours we worked; when we complained, the foreman would then get upset and say we were lying and that we were too slow. This lasted more than a year, until they installed a 'punch in' machine for the workers. We never talked to the owners about the issue because we were afraid to lose our jobs.

For these informants, the discovery and complaint about irregularities on their paychecks brought harassment and contempt from their supervisors. However, Teofilo's case shows how workers are often willing to put up with wage theft and harassment because of fear of losing their jobs. 
In another example, Miguel, a Guatemalan worker, explained how he was a victim of wage theft at two separate Nurseries.

This one time a gentleman asked us to work on December the first, he told us that he would pay us $\$ 100$ dollars each for a full day of work, and when we finished at $7 \mathrm{pm}$, he only gave us $\$ 50$. We complained and he responded that he had lost a saw. We later heard that this was a common practice by this gentleman to have a reason of accusing us unjustly; that was his way. He started telling us that he would call immigration and harassed us.

On the second occasion, Miguel explained that after being owed several weeks of pay checks, he confronted his employers.

I talked to them because my backed up salary started accumulating for several weeks, I even tried to negotiate with them, I told them that if they had no money they could pay me only half. They then began giving me a hard time, trying to intimidate me and told me that I could go to whoever I wanted to, that they were not scared.

Having been a victim of wage theft on a couple of occasions, Miguel's experiences serves to illustrate the relation that exists between complaining to supervisors and the harassment practices that employers in turn develop toward their employees.

Jose's, Teofilo's and Miguel's experiences are consistent with the documented cases of wage theft from the literature and media reports, and show how "shaving" hours, late payments that drag on for weeks, not paying amounts agreed upon, and paying below the minimum wage are practices that affect workers' salaries in an industry which yearly and steadily reports multi-billion dollar earnings.

These examples not only show some of the workers' lack of information regarding the state's hourly minimum wage, but also highlight the lack of information available to them at their workplace. Many of us may be familiar with guidelines, posters and information displayed in lunch rooms or in areas accessible to workers. Unfortunately, this does not occur regularly in plant nurseries and farms where many employees work, eat, are paid, and rest in the fields, and seldom enter offices and other management spaces of the companies that employ them. Many workers also expressed an 
unwillingness to share wage information with their fellow co-workers; thus, an informal network where information could be shared among workers was absent. The lack of such networks among workers creates advantages for unscrupulous employers because it maintains workers uninformed of payment standards or unaware of unfair labor practices.

The issue of information is further exacerbated by the worker's language skills. Many workers in this industry are illiterate or completed very few years of education. For instance, Martin a Guatemalan worker told me that he had never been to school, "Not one day. Let me tell you, my parents were very poor and they couldn't give me an education, that's how I grew up, and as I got older I just started working." Like Martin, several workers told me that they had never been to school. As a result, the existence of posters, even in worker accessible areas would not be useful unless someone took the time to explain their contents to the workers. Aggravating the situation is the fact that many workers, mostly of Guatemalan origin, are native speakers of indigenous languages, such as K'iche and Mam, and have a difficult time communicating in Spanish. These workers come from indigenous parts of their homeland, and even their Spanish is fragmented and limited. Antonio, who is Mexican, told us, "I keep myself informed, and for them (indigenous Guatemalan workers) this is hard because they speak their own language, some of them even have a hard time finding a job because they are shy and are afraid that they will not be understood." Again, even in places where standard, bilingual (English and Spanish) posters are available, many indigenous workers would be left in ignorance of their labor rights and their employer's responsibilities.

For many of the workers, education, language skills, and harassment are some of the issues they have to face in an environment that places emphasis on capital 
accumulation and productivity. Many of the workers in my sample show concern for the conditions of other workers working along them. Alberto from Mexico told me that, "There are other workers that get paid less than the minimum (wage), they are getting about $\$ 5.15$, a gentleman told me at the nursery. Some of these guys are learning to spray, so the bosses say that they first need to learn in order to get a raise." Another worker, Jonathan, also from Mexico, explained that, "I often hear other workers complain because they get paid very little, and sometimes they give them a lot of work, it is not fair that some get paid more than others, there are some that just started working and they get paid better than some that have been there for longer periods of time." Both of these statements demonstrate a level of frustration regarding the ambiguity of pay structures in the industry. Many workers did not know how payment rates were determined, and often expressed concern about this seemingly unfair situation.

Many of the issues that the nursery workers face are further accentuated by their lack of knowledge of organizations, agencies, or institutions that can help them in situations like harassment and/or wage theft. The situation is further aggravated by a worker's lack of legal immigration status. As Jorge, who is from Guatemala, described, "I would not know where to go, I believe I would report them (negligent employers), but we do not know anything. In the first place since we have no papers we get very scared, we are always very scared because we have no papers, we are not safe." Tito, another Guatemalan, described the situation stating that, "The only thing that I know, someone told me, that there is a house in Washington where they would help you, but I really do not know where it is."

In addition to issues of unpaid wages and misinformation, the field-workers of the plan nursery industry are provided very few benefits by the employers of the industry. None of the workers with whom I spoke receive health insurance or overtime pay for 
work performed after the 40 hour limit. The only benefit that workers receive according to both employers and employees is a week of paid vacation during the year. In the area of health benefits, the employers argue that they insure their workers through worker's comp in case of an accident on their grounds, but that providing health benefits would significantly increase their costs of production and render them uncompetitive to firms that did not provide health benefits.

During a large conversation with Mr. Smith, the large co-op manager in north Florida, the issue of health benefits for workers was discussed in depth. Our conversation took place after the healthcare reform approved by the U.S. Congress in 2010 and which included an individual mandate to those individuals not covered by their employers as well as penalties for employers who did not provide health benefits to their employers. This mandate by the federal government angered Mr. Smith as well as other elite members with whom I spoke, since they perceived the measure as a form of strong governmental intrusion on private entrepreneurs and one which could have detrimental repercussions on the profits of plant nursery producers. At the end, all of the producers and trade representatives expressed that they basically cannot afford to provide health insurance while remaining competitive. But this market behavior again has negative repercussions for industry workers who must assume the hidden costs of healthcare when they become ill. For the most part, the workers expressed to me that they just wait for any illness to go away and rarely use any health services.

Some of these issues are exacerbated by the fact that structural farming and agricultural conditions often prevent farm workers from joining unions and bargain collectively. In early parts of the $20^{\text {th }}$ century the nature of farm labor, where small familyowned farms had traditionally been responsible of farming production, and the seasonal and temporary nature of the work made organizing farm workers incredibly difficult for 
unions in the U.S. (Marshall Jamieson 1946). But even with the expansion of commercial agriculture over the last three decades, sporadic efforts to organize agricultural workers have only fostered occasional success in organizing the country's rural workers (cite exceptions). It has been extremely difficult for plant nursery workers to organize and fight for better wages or any kind of benefits. While there are several organizations in Florida that tend to the needs of workers, their work suffers from limited funding and is complicated by the legal status and language issues that plague immigrant workers.

During time in the field, I volunteered some of my time at WeCount! and at La Asociacion Campesina (The Farmworker Association) of Homestead and Florida City. Both of these community organizations are dedicated to empower the area's day laborers as well as the farm and plant nursery working populations though leadership, education, training, and a variety of services that range from helping them collect unpaid wages to solving legal disputes and other labor issues. At We Count! I helped to develop an intake form and a process to determine the extent of wage theft and other kinds of abuse that workers in the area were experiencing and, which, was later used to recover wages on behalf of the workers. At The Farmworker Association I helped to organize community events and every December since I did participant observation with them, I do a toy drive for the children of the organization's members.

Through my participant observation at these organizations, I was able to understand that these are organizing models that emerge in what seems like a complete absence of unionism in the state's farming industry. There are definitely bridges and communication between some unions and the homestead organizers, but for the most part I sensed a large deal of frustration within the organizations toward the unions and particularly their absence in the area. It was often my sense that the work performed at these two organizations, although incredibly valuable, was slow and often failed to address some 
of the structural labor issues that exist in these industries. To be clear, however, I think the speed of the work often had to do with budgets and money rather that with the abilities of those organizers who run the organizations.

This was clear for instance in a couple of programs in which I had the opportunity to do participant observation. First, when WeCount! launched its wage theft campaign, designed to address the pressing issue of unpaid salaries and other kinds of wage and hour violations in the nursery industry, the organization developed an intake protocol and assigned a pro-bono lawyer to help those workers collect their owned wages. This was an excellent service that WeCount! had been able to create, as hordes of workers were able to get legal representation and collect their money. However, the system did little to stop operators in the area from continuing such practices. Second, during my time at The Farmworker Association, I used to frequent the many safety training sessions that the organization arranged for plant nursery workers. During these sessions, members were given training on safety and precautions when fumigating at their workplace, as well as tips on what to do when using and lifting heavy objects. In addition the organization provided the workers with long sleeve shirts, boots, hats, and other garments necessary to withstand the sun, pesticides and other dangers that they will encounter while on the field. Again, although these training sessions where incredibly valuable, especially in creating awareness and solidarity among workers, to me they did little to stop what seemed a widespread lack of training and safety precautions on the part of industry operators.

Clearly, the work that these organizations do to organize and empower workers is incalculable, but overall they show the limitations that workers and organizations have in order to address structural issues on the industry. The clear absence of unions and the limitations of these community organizations add another layer of marginalization and 
isolation to industry workers. For those workers who are lucky enough to belong to organizations such as WeCount! or The Farmworker Association, adverse conditions at the labor place seem to have some degree of security at least in the sense that there will be people willing to train you and help you in case something illegal takes place. However, for thousands of workers who - as I indicated earlier on this chapter - have no knowledge of those state organizations that could help or for those who fear even leaving their house on weekends because of the thought of deportation, conditions are still dire.

\section{Discussion}

A first issue I set out to explore in this chapter was related to variety of institutional disadvantages that emerge from an uneven system of economic and emotional investments that migrant workers must make and which are associated with their migration and settlement into the state's plant nursery industry. Specifically, I explored the investments that the workers must make once they make the decision to travel abroad and settle in the Florida communities that provide employment to the plant nursery industry. As I demonstrate in this chapter, there is a severe imbalance in the investments that workers must make vis-à-vis their employers. Some of these investments include the emotional and economic commitments that the trip entails, including transportation, rents, smugglers, nutrition, and separation from family and friends which can last for several years. In addition, once settled and employed, nursery operators transfer the costs of healthcare to their employees who must run with the medical bills when sick, even when their illness comes from prolonged exposure to agricultural chemicals or to lower-back issues related to the work associated with their trade. 
The second question I sought to answer in this chapter asked about the implications for the large, immigrant labor force of the Florida plant nursery industry in terms of working conditions, rights, and benefits. In this area, I found that within my sample of workers of plant nursery production in Florida, benefits are scarce as none of the workers I interviewed receives any form of healthcare, unemployment insurance, overtime pay, or contracts in this multimillion dollar industry. This was corroborated to me by all of the operators with whom I spoke, who often argue that the price of insurance and other benefits is too high and would take away the profitability of the industry if it were to be mandated.

In terms of wages, through my research I uncovered forms of employers' wage and hour violations who cheat their workers of their wages by paying below minimum wage and sometimes not paying them for days or weeks of pay. Although none of the operators with whom I spoke supported the idea that this kind of behavior was taking place in their industry, the stories of the workers did seem to indicate that the issue was pervasive particularly among unregistered and uninsured operations and often by other Hispanic nursery owners in the southern region of the State. The issues of wages were often associated with harassment when workers complained, or with intimidation and blackmail associated with the immigrant status of the workers.

Finally, the absence of unions and the relative diminished capacity of labor oriented community organizations to help the workers make it particularly difficult for workers to complain to bodies that could intercede for them in recuperating lost wages. In addition, the opportunity that workers have of complaining to the federal DOL is often suppressed by the workers' fears of deportation. As a result they often remain quiet and fail to report abuse from unscrupulous employers. 
Grouped together, the conditions that the immigrant workers must face create marginal spaces for their livelihood in industries and areas of the developed world. For those workers of the plant nursery industry whom I interviewed and to so many like them, the investments and risks they must take to come and work in the United States continue years after their arrival in the country. In the state of Florida thousands of workers must continue to negotiate with unfair wage systems, lack of healthcare, and lack of unemployment benefits while often living lives of fear and isolation due to their migratory status. These conditions coupled with lack of unions and with limited organizational support also add to the vulnerability of a labor force, which, despite their sacrifices - human and economic - continues to get scrutinized and marginalized by those who benefit most from their presence in the country. 


\section{GLOBAL DISCONTINUITIES}

I first got involved with the plant nursery industry in 2007 when as a graduate student at Florida International University the opportunity arouse to study the frequency and extent of wage and hour abuses taking place in a variety of towns in the state of Florida. My early involvement with plant nursery production in Florida took place as I spent time in the offices of WeCount!, a community organization that actively sought to help their members collect unpaid wages from their employers as part of their overall organizing strategy. WeCount! Operates in the Florida town of Homestead, which is the epicenter for most of south Florida's food and ornamental agriculture and which is home to large immigrant communities of Mexican and Guatemalan agricultural workers. As part of my original research of wage and hour violations and wage theft, I documented the cases that many of the area's nursery workers were seeking to resolve through the help of WeCount! I also attended commission meetings that had agendas that pertained to worker issues, and I met many political and organizing figures who were in one way or another related to the plight of the workers.

My involvement with industry groups also led me to meet a variety of industry players who ranged from workers to community organizers and public officials, many of whom were in one way or another victims or investigators of the kinds of abuses that were allegedly taking place within the industry. During this time, I also met a variety of individuals whose lives I thought were embedded in very marginal spaces of class, labor, and migration. Many of these men and women were immigrants from the global south, specifically Mexico and Guatemala, who had come to the U.S. in search of a piece of the "American Dream," but who seemed to me to be living in the geographical and cultural margins of a society that knew little about them and which did not acknowledge the reasons of their presence there. 
As I delved deeper into the fabric of plant nursery production and of the community dynamics taking place on its surrounding areas I discovered that many of the assumptions about globalization and labor migration that I had learned in graduate school did not match the kinds of processes taking place at the ground level. This led me to question the process by which immigrants come to the state of Florida in search of jobs in the plant nursery industry and the ways in which regulation and process work to influence their migration, their economic and labor integration, their fragile permanence and their marginality. Ultimately my questioning led me to "look up" at the industry with an institutional focus on how structural processes are actually formulated and institutionalized. I knew that the focus of my work needed to be the workers, their strife, and what I perceived to be their marginalization, but began to consider the idea that institutional arrangements associated with the industry's elites held the answer to many of the questions I had formulated.

An important observation that I made in early stages of my study of wage and hour violations concerned the way in which agricultural regulation protects the status of plant nursery production in the U.S. Plant nursery production largely produces ornamentals and is different form food agriculture in that the goods produced are not highly perishable and thus - at least in theory - can be produced in other areas of the world. However, a strongly maintained regulatory system ensures that no planted organisms or soil are imported into the U.S. This makes the plant nursery industry dependent on low wage labor, which in the U.S. is significantly immigrant labor. This type of regulation holds the key for a system that in many ways defies the notions about globalization that have become embedded in public and academic discourses while also serving as the justification for a system that enforces old and new marginalization and alienation of 
immigrant laborers who are often rendered voiceless by those political and economic structures that benefit from their labor.

One of the objectives of this dissertation was then to understand how the plant nursery industry in the state of Florida has been able to remain competitive amidst a globalizing economic environment where industries of the developed world have consistently sought to outsource production to less developed areas of the world where labor is cheaper and where labor and environmental regulation are more flexible. This process has been analyzed and presented by a variety of scholars as one of broad structural characteristics in which, multinational corporations in search of higher profitability and efficiency have been able to move operations abroad under the explicit support of their nations' governing bodies. However, as plant nursery production in the state of Florida demonstrates, the conditions for producers in the developed world are not homogeneous and can vary greatly according to the products being made, the conditions and interests of producers, and the political arrangements that are forged among powerful actors within specific industries. The success and permanence of plant nursery production in the state of Florida, thus, responds to a variety of factors, which I sought to better understand and to contextualize within current frameworks of global economic development.

\section{Research Questions}

\section{Permanence and Success of Plant nursery Production}

My first research question for this dissertation was why and how has Florida remained one of the most important sites of nursery plant production for the U.S. market amidst neoliberal economic restructuring of the last 3 decades? Nursery plants are among the largest and most important agricultural commodities in the state of Florida, along with fruits, vegetables and forest products. In the state there are more than 4,700 
commercial nursery and greenhouse farms with industry sales in 2010 estimated at about 1.7 billion in total sales. The University of Florida estimated that employment impacts for the nursery/greenhouse industry in Florida accounted for approximately 98,000 jobs. In addition, the Industry ranks second nationally in sales and production of nursery plants.

At first, it seemed clear to me that part of the success and permanence of the industry in the state could be attributed to sanitary and phytosanitary regulations imposed by the federal government. Some of these regulations date to the early part of the $20^{\text {th }}$ century and have been enacted to protect native organic life such as plants and animals from invasive organisms that could come into the country in potted plants and soil. The existence of SPS regulations, however, is often contested by trade groups and nation states who feel that these are used by economically powerful countries to protect specific industrial sectors as opposed to protecting organic life. The use of SPS regulations has created many debates amidst the establishment of free trade agreements between the U.S. and a variety of neighboring countries who argue that the regulations ignore the geographic and ecological conditions which have no connection with political lines. In this sense, those who oppose the use of regulation argue that nursery plants for U.S. markets could be grown as efficiently in northern areas of Mexico or Caribbean Islands near Florida since these share climate zones that are not defined by political borders. Those who oppose SPS regulation argue that the conditions give powerful nations a disproportionate economic advantage by protecting certain agricultural sectors from international competition.

The nature of SPS regulation was often the topic of my conversations and interviews with members of the Florida plant nursery industry elite. This group ranged from owners and operators of the industry to professional business representatives and federal 
regulators. Without exception, all of the elite members I interviewed saw SPS regulation as an essential requirement to protect Florida ecosystems from invasive plants, insects, and pests and only saw economic protection as an indirect benefit of the regulation. Operators and regulators alike argued that the measure helped to keep the industry alive because having invasive organisms could affect the state of the industry if their crops became infected or sick, but they rarely acknowledged it as a form of direct economic protectionism on the side of the federal government as it is often claimed by critics of strong SPS regulation.

Industry elites are highly aware of the role that SPS regulations play on industry survival. As a result they spend invaluable resources on political lobbying, research, and control in order to maintain a strong body of regulation. While most Florida nursery producers are small to medium sized, they are well organized under a variety of state and national business groups such as the Florida Nursery Growers and Landscapers Association (FNGLA), the American Nursery and Landscapers Association (ANLA) and the Farm Bureau of Florida, which lobby state and federal legislators in favor of plant nursery owners and operators.

In many ways, the overwhelming support for SPS regulation in the nursery industry is founded on a socially constructed ideology about the unknown effects and dangers that invasive plants and organisms could have on local ecosystems. Certainly, by arguing that the beliefs and ideas of industry elites regarding SPS regulation are socially constructed I do not mean that some of their fears are unfounded, but rather that in many ways the discourses and market-place behaviors of industry elites have been greatly influenced by the claims of powerful actors in the scientific and political communities, and thus have been widely accepted as ultimately true and immovable by a variety of industry operators and professionals. 
The socially constructed nature of the regulation ideology was made clear to me through many levels of the industry professional structure. In my interviews with scientists of the USDA the defense of a strong SPS regulation was consistently presented to me as a necessary protection to our state's ecology, but when I probed deeper, the scientists conceded that political lines do not adequately represent geographical areas or hardiness zones and most importantly that a large amount of invasive organisms make their way into our state through the millions of travelers and imports that come into the country through south Florida ports on a yearly basis. Still, the scientists' discourses were based on the idea that science should serve as the ultimate arbitrator and guide to determine the course of regulation and that it is their research that supports the policy both at the state and federal level and not political actors as many international trade analysts argue.

For industry insiders who work for and represent the professional associations, the science based claims of regulators serve to justify their own discourses about regulation and in turn they use the claims to lobby political legislative bodies in support for strong protectionist measures. This is also true for operators, who organize together through the existing professional organizations in efforts to maintain their market position in a clear opposition to international competitors or national competitors who may seek to produce nursery plants abroad. In this sense, scientific claims become part of a strong and well unified body of regulation that is supported by a widespread ideology and discourse of ecological and economic protection and which have real implications for the success and permanence of the industry in the state and in the U.S.

Another important factor embedded in the interaction of industry elites lies in the relationships that they have forged between one another. It became clear to me during early parts of my filed work that the lobbyists, professional representatives, 
organizational leaders, economic researchers, and many of the prominent operators of the industry have very close working and even personal relationships with one another and that these connections often stretch to the regulators of the industry. These relationships are forged through a variety of committees, boards, and initiatives that bring a variety of actors together and which directly force them to work with one another. They also have a strong influence in the way contingency to threats from invasive plants or insects works, as the groups are able to quickly disseminate information across the state's nursery operators, scientists, and professional representatives. In addition, the many boards and committees in which members of the plant nursery elite sit help to craft and reshape a variety of messages, discourses, and policies that effectively shape the course of the industry.

In many ways the success, permanence and durability of the plant nursery industry in the state of Florida can be attributed to a combination of factors embedded in the beliefs and interactions of industry elites and the de-regulatory policies that they have been able to institutionalize. First, because regulation is in great part driven by the ideologies of powerful actors within the industry and supported by the collective efforts of thousands of small and medium sized producers, it has become part of a greater collective effort to maintain a strong market presence, despite recent trends to outsource production in a variety of industrial sectors of the US. Second, the relationships among industry elites - including regulators, operators, and professional representatives allows for a very unified system of policy creation which is consistent with many of the neoliberal trends and theories of recent decades. In this sense trade regulation is the result of a de-regulation in the process of policy creation and management, where decisions are made in an overt agreement between the industry insiders and later proposed and lobbied to the appropriate legislative bodies at the state and federal level. 
In the end the mutual bonds that develop between industry elites and policymakers create new forms of regulatory regimes that are capable of exercising a great deal of power on their own behalf. Within the context of neoliberal restructuring, this process becomes one of deregulation of regulatory mechanisms. In other words, what industry elites have been able to achieve through lobbying, and through working closely with regulators and policymakers is to effectively take control of the process of policymaking. Similar phenomena have been explained by traditional globalization scholars as a process of de-evolution of state powers to private interests, but my evidence seems to indicate that rather than giving full power to private interests, the state deposits its policy making and enforcement capacity to an elite group conformed of actors of the private sector, educators, and regulators of governmental agencies.

Discontinuities in Globalization: Theory and Trends

A second question I sought to answer through this dissertation was whether or not the conditions of plant nursery production in the state of Florida fit the theories of neoliberalism and globalization. Here my findings are mixed. Such theories do help explain the ways in which de-regulation has facilitated the industrial success of the plant nursery industry in the state. However, in several respects the conditions that I observed require a new way of looking at globalization, specifically since local conditions and institutional arrangements of the plant nursery industry demonstrate that processes of global production, consumption, and trade assume a variety of discontinuous characteristics.

Consistent with neoliberal ideology, trade and labor regulation in the State's plant nursery industry have become largely removed from governmental bodies or become embedded in an overt relationship between private interests and governmental regulatory agencies. Yet, consistent with the criticisms of neoliberalism the State still 
assumes the role of ensuring an appropriate institutional framework. The larger framework, beyond the purview of this dissertation, includes 'official' structures such as the military, defense, police, and the legal system (See Harvey 2005; Clarke 2005). This dissertation's focus on Florida's plant nursery industry adds the institutions that affect immigration control, wage labor, and the protection of the environment through controlling imported live plants.

Much discussion about the economic restructuring of the last three decades has centered on the way through which political and economic elites have succeeded in consolidating a position of power and accumulation through the establishment of influential networks and more specifically through the implementation of regulatory regimes (Rapley 2004). Thus, it can be argued that in modern capitalist society, both political and economic elites are related in mutual bonds of dependency that allow them a high degree of political leverage and the ability to exclude the masses from the political process. This notion is largely present throughout the literature on neoliberalism and globalization, although different authors have conceptualized the issue as one of power restoration to the economic and political class (see Canterbury 2005; Radice 2005; Tabb 2001; Rapley 2004).

Whether in the form of authoritarian or democratic governing, the relationship between economic and political elites must work within the structure of the state. In this sense, the neoliberal state can be described as a governing apparatus for which the freedoms embodied in it reflect the interests of private property owners, businesses, multinational corporations, and financial capital (Harvey 2005). It could be argued that the state in turn responds to claims from capital by producing new forms of legality, which advance the interests of certain economic actors while weakening those of others (Sassen 1998). In this sense, it becomes clear that globalization "is about relations of 
relative power, dependence as much as exchange, and how otherness becomes naturalized or provokes resistance. Far from being a merely technical matter, globalization is a deeply political process (Tabb 2001; 13)."

In Florida's plant nursery production, this phenomenon is visible through the economic, environmental, trade, and labor policy driven by agreements between agency regulators and the needs of the operators. Within this context, policies that require approval or enforcement from state bodies of regulation are proposed and lobbied through strongly unified messages by both local scientific regulators and professional representatives that make claims on behalf of industry operators. In the state, thus, plant nursery policy-making and regulation have become largely removed from governmental oversight and justified by powerful industry insiders and regulators within the discourse that industry insiders know best about the kinds of policies and regulations that strengthen and protect the industry. Again, this perception fits well within the neoliberal prescription that intrusive government intervention would be detrimental for the health of the industry, and in a very real and practical way Florida's Plant nursery elites hold strong commitments to uphold their values about industry control and regulation.

But an interesting feature of Florida Plant nursery production lies in the process by which local elites have taken over the regulatory process for the benefit and protection of their own industry. As I demonstrated in chapters four and five, Florida plant nursery production is dominated by thousands of small farms across the state and not by powerful multinational corporations. This is a nuance within the existent theoretical frameworks that prescribe globalization as process in which multinational corporations drive economic policy and expansion across transnational borders. In the industry, thus, it can be observed that the establishment of regimes by political and economic elites has also had an impact on traditional modes of commodity production in the developed 
world. Berger and Piore (1980) foresaw some of these issues as embedded in the relationship between market expansion and the survival of traditional industries ${ }^{21}$ where the survival and permanence of the traditional sector and its role can also be understood as resulting from inherent features and tensions among actors in advanced industrial societies. Just as in the neoliberal context of globalization, the resilience, adaptation, and reproduction of traditional industries and business groups are centrally related to economic incentives and market conditions that are politically arranged, and which can be observed in the state's willingness to overlook violations in labor practices, minimum wage, and working conditions. As in the case of global economic development, these relationships are forged by values, norms and expectations which groups in society hold and which result in political decisions to protect the role and function of the traditional firm (Berger and Piore 1980).

The intentions and institutional practices of industry elites has resulted in a strong protection from international competition or from outsourcing, thus, reversing the trends in neoliberal globalization in a variety of other industrial sectors across the developed world. In this sense, the State of Florida presents an anomalous relationship to those theories that indicate that unskilled jobs that do not need to be performed within the most highly developed countries are outsourced to where labor is cheaper and more flexible. Traditionally, cheap and specifically immigrant labor has been required in developed countries only for the work that is place bound, such as cleaning of office buildings, and highly perishable agricultural goods. Nursery plants on the other hand could be grown more "efficiently," that is with lower production costs, in many other countries, such as is

\footnotetext{
${ }^{21}$ Berger and Piore (1980:91) define traditional industries as those that produce the same goods and services as other, modern firms in the market, but which are characterized by smaller firm size, higher labor capital ratios, lower productivity, and other characteristics associated with small, independent property owners, farmers, shopkeepers, artisans, and certain small and medium businessmen.
} 
the case with much of the cut-flowers sold in the U.S. Yet, neoliberal re-structuring in the state's plant nursery industry has created an environment where de-regulation serves to constrain market freedoms of local and international actors and which carry important implications in theoretical and practical terms.

At a theoretical level, it could be better argued that globalization, rather than being a one-way process, is a process of multiple dimensions, directions, and outcomes which operate in rather discontinuous modes. Globalization is said to be mediated by a process of governance networks that potentially operate from the local to the transnational and which require a variety of social mechanisms to enforce contracts and standards of judging what is considered permissible behavior by participants. I argue that these governance processes need to be analyzed further because they shed light on how decisions made by a variety of actors influence the degree to which global configurations of capital, culture, ethnicity, and class are produced in localities of the developed world. It is the analysis of a variety of interactions between influential - and their relationship to less and more influential - actors that sheds light on the processes of globalization occurring in the world today. Thus, the differences in power relations and dependencies among economic elites, their workers, related governmental agencies, and policymakers are essential themes to the understanding of global re-configurations around the world.

Traditional views of the process of globalization taking place in the world since the 1970s often describe the process as the transformation of capitalism through international trade regulations to benefit the world's powerful corporations amidst a process by which technology and communication help to shift sites of production to areas where labor is cheaper and more flexible. Such understandings of globalization have also been complemented by cultural theories that promote an evolutionary view of 
globalization, and which focus on global reproductions and re-configurations of new forms capital, labor and technologies (Tsing 2005). These views have come to dominate the academic readings and popular perceptions about globalization with narrow definitions which essentialize globalization as a one way process in which labor and the environment in peripheral sites are transformed by the direct efforts of powerful actors in the developed world. But the evidence gathered from the state of Florida's plant nursery industry demonstrates that the influence of those power elites also serves to create conditions that are not consistent with other global modes of economic expansion.

In practical terms, it can be argued that the relegation of state powers to the elites has not only resulted in market behavior that is contradictory to neoliberal thinking by creating strong layers of regulation and control, but also by increasing the dependence that the industry has on low wage workers of the developing world. In essence, a strong commitment to SPS regulation; the exemption of agriculture from the NLRA; the rural nature of most such employment, the unskilled or semi-skilled nature of the work, and; the political clout of the industry over politicians representing these business interests have had the unintended consequence of mobilizing thousands of low wage workers to the state of Florida in an environment where protectionist measures make nursery plant production a place bound economic activity for the workers. These contradictions are not only visible in the labor dependence of employers, but also on the policy implementations instituted by labor and immigration regulatory bodies.

The case that I present about plant nursery production in Florida, thus, illustrates the processes through which business, government and science build a variety of global socio-economic structures. Whereas the formula of multinational corporate labor outsourcing is perhaps the best known component of this process, specific industries in the developed world explicitly apply these methods and ideologies for their own benefit 
in ways that can have different outcomes. In this case, because the resource they control is physical land and soil, their pursuit of maximum profitability with the cooperation of regulators and scientists requires, instead of free market, an appeal for localized protectionist strategies.

\section{Reproducing Inequalities: Implications for a Marginal Labor Force}

My early research with plant nursery workers originally led me to look further into Florida's plant nursery industry. While that original work centered on wage theft and worker abuse within the industry, I decided to look at the structural conditions that affect the labor force in relation to their economic integration, patterns of migration and the processes of marginalization which they must endure. To this end I interviewed both employers and workers, hoping to get a clearer picture of how the values, discourses, and policies of industry elites compared to the economic conditions and life outcomes of the workers, their families, and the communities in which they had settled.

When I spoke with industry operators about the conditions that their workers faced, they often took pride in employing such marginal individuals because to the employers this was an opportunity for immigrant workers to assimilate to US culture and to its economic structures. Many of the operators spoke of their workers with pride, often relating stories of success about workers that had learned English while working for them and about workers who had moved up the company ladder to become managers or foremen. At the same time, the employers often displayed a strong sense of racialization toward their workers and their abilities. Most of the operators thought that the indigenous workers were better suited for farm labor because this is what they had been doing at their homelands before coming to the US and because they believed that American workers had become lazy and unwilling to work the land. Yet, when I asked why they did not provide better wages, training, or health insurance for their workers, 
operators often spoke about their bottom line, arguing that as employers they had to choose between giving jobs or benefits to people, but that they most certainly could not do both.

To me, employer discourses and expectations about their workers' labor prospects and assimilation were consonant with traditional conservative values about individual freedoms and hard work as mechanisms to achieve economic success. However, what did not come across as clear to me was the employers' lack of awareness that by expecting individuals to succeed on their own terms through hard work, discipline and dedication, a system of uneven investments and returns is institutionalized and maintained. In the employers' characterizations of their workers, there exists a blind spot about the sacrifices and investments that workers must make to reach their industrial sector.

For the workers of Florida's plant nursery industry, the trip to Florida is often one of unlimited economic and emotional investments which do not end when the workers find jobs and settle in the state's immigrant communities. For the employers, the need for an employee is often satisfied with an announcement to one of their workers, who in turn usually call a relative or friend to fill those jobs. However, the experiences of many of the workers are filled with economic investments that range from selling or mortgaging their lands in Central America or with borrowing money from neighbors. In addition, the journey through Mexico and the US often entails risking their lives at the hand of law enforcement and smugglers in the Mexico -US border, and later risking hunger and uncertainty as they finish the trip to the State of Florida. Once settled, they must endure the risks of health and unfair wage and labor practices as the employers do little to provide such care. The process is complimented by a growing system of deportation and immigration control on the part of the US government, which in the aftermath of the 
terrorist attack of 911 and of the recent economic recession have heightened border security and immigration control.

By hiring undocumented workers, employers of the plant nursery industry have in essence tapped into a seemingly unlimited source of cheap and vulnerable labor. This is not to say that the employers do not care about their workers' wellbeing, but at a structural level the benefits for the industry are immense as the costs of labor in terms of health, training, education, wages, and relocation are transferred almost entirely to the workers of the industry. This has other important ramifications for the labor force, for it creates marginal communities of individuals who have little protection from unfair state and market conditions and policies, perpetuating the existence of a powerless and voiceless underclass.

One way in which I thought it would be possible to observe the degree of marginality of the workers was through the cases of wage abuse that originally drew me to do research in the industry. My findings in this area suggest that wage theft occurs in similar ways to those previously reported by the media and research literature (see Mahler 1995; Stepick 1998, Pisani and Yoskowitz 2002; Ness 2005; Fine 2006; Stephen 2007, Bobo 2009). I found that paying under the minimum wage, "shaving" hours, and simply not paying wages due are some of the ways in which workers suffer abuses from their employers. My analysis also indicates that harassment often results in those cases where employees were willing to speak out and complain. These findings are important because they empirically document the existence of wage theft within the plant nursery industry, although none of the operators with whom I spoke admitted to this kind of behavior. However, my findings suggest that a lot of the wage and hour abuses tend to take place within those nurseries that are not registered with the state and which are the 
same ones that legitimate operators accuse of bringing down prices and creating uneven competition.

In many cases, it was the worker's lack of knowledge of and access to information regarding laws and rights at the workplace that seemed to be partly responsible for the wage and hour violations. In this area, I found that the majority of my informants had no clear idea of what the state's minimum hourly wage was. Many of them complained to me that there were no posters informing them of basic work standards or regulations at their job sites and that they would not be able to extract such information from their employers. The workers also expressed that reliable information is not available from coworkers. Indeed, little information about wages is shared among workers. In addition, several informants revealed that they would not know who to seek information or help from if they experienced wage theft or any other form of abuse at their workplace.

The lack of knowledge about informational and assistance resources is exacerbated by the fact that many of the workers in the industry are partially or completely illiterate and, thus, would not be able to read written information even if made available to them. Also, many workers come from rural areas in Guatemala and lack Spanish skills, which could help them in Miami-Dade's highly Hispanized environment. In addition, for many of my informants, complaining about irregularities on their paychecks brought harassment and contempt from their supervisors, illustrating the strong relation that exists between complaining to supervisors and the harassment practices that employers in turn develop toward their employees. Many operators, as I demonstrated in chapter six fire or harass their workers soon after these complain about their unpaid wages.

In addition, I also found that the absence of unions and the relative diminished capacity of labor oriented community organizations to help the workers make it particularly difficult for workers to succeed in getting better wages or at least better 
working conditions from their employers. There are hardly any official avenues to complain when abuses are taking place or bodies that could intercede for them in recuperating lost wages. Furthermore, the resource that workers have of complaining to the federal DOL is often suppressed by the workers' fears of deportation. As a result they often remain quiet and fail to report abuse from unscrupulous employers.

The case study I present here serves to demonstrate the way in which conditions that the immigrant workers must face create marginal spaces for their livelihood in industries and areas of the developed world. Like many of the plant nursery workers that I interviewed, the investments and risks they must take to come work in the United States continue years after their arrival in the country. In the state of Florida thousands of workers must continue to negotiate with unfair wage systems, lack of healthcare, and lack of unemployment benefits while often living lives of fear and isolation due to their migratory status. These conditions coupled with lack of unions and with limited organizational support also add to the vulnerability of a labor force, which, despite their sacrifices - human and economic - continues to get scrutinized and marginalized by those who benefit most from their presence in the country.

\section{Crossing Borders: What the Theory Books Don't Tell You}

A final question I sought to answer in this dissertation was if and how labor-migration trends in the plant nursery industry are consistent with current theories of globalization or if they represent anomalies in their relationship to integration, policy implementation, and institutional organization of labor migrants in the developed world. From my analysis, it is clear that while some theories correctly address some of the issues related to migration and institutional integration of labor migrants, other views need to be better addressed or incorporated into the discussion. As I discussed in chapter 4, neoclassical explanations of migration provide a rather economic argument on the conditions that spark the 
movement of people from economically depressed areas to more developed areas in search of better wages. Although I saw evidence of such economic calculations in the part of most of the workers within my sample, it is evident that such theories fail to explain the geographic and industrial destinations that migrants choose.

Another set of explanations argue that the decision to migrate and its destination are often related to the social networks that people have pre-established in developed areas of the world. In this sense again, evidence from my sample of workers suggests that they chose to travel to areas where family members and friends had previously been established and could offer support in housing and labor markets while alleviating the newcomers' anxieties of learning some of the customs and practices of the receiving culture. Still, theories that concentrate exclusively on social capital neglect the larger socioeconomic structures of developed countries where as the manufacturing base erodes and a two tired service economy intensifies, more jobs are made available for low-income migrant workers of the developing world. Such theories appropriately address the structural conditions that stimulate large numbers of low-wage immigrants in the developing world to migrate, despite a growing unemployment and the proliferation of dead end, wage-depressed jobs at the receiving countries. These theories, however, fail to address how the needs of specific industries and specific migrant workers are met and fulfilled in an increasingly globalized marketplace.

Certainly the data that I collected from my sample of workers validates many of the already existing theories of labor migration. However, the stories and lives of many of the farm workers that I interviewed substantiates the idea that the migration of individuals may also be based on broad institutional arrangements that span across continents or geographical regions in spite of the existence of rigid political, economic, racial, and class borders. To be more specific, there seems to be a lack of discussion of 
the specific efforts of small industrial producers in the developed world to maintain a constant supply of immigrant low wage labor for their business (see notable exceptions in Portes 1997; Cameron et al. 2010). In the case of plant nursery production in the State of Florida, the values and attitudes of industry operators seem consistent with those of other Agriculture industry operators who have bypassed African American or White laborers in search of more docile workers and flexible environments (see Hollander 2008). Clearly this is not only about micro or macro economics, but rather about values and attitudes of institutional actors in different locations of the world.

What this means for the plant nursery industry in Florida is that while employers must negotiate with the demands of growing real estate prices, of big chain suppliers that dictate the price of plants, and of generalized low wages that compete with those paid by companies in the developing world, they also have very clear definitions of the kinds of workers that they want at their operations and of the process to attract them to the state. For workers in those developing areas, that means navigating through some of the economic, social, and structural areas described by the aforementioned theories, but also negotiating the kinds of jobs that best fit their human capital, including their technical, educational, and job skills. Thus a special kind of fit develops between small business operators in plant nursery production and the workers thousands of miles away that are deemed "adequate" because of the kinds of skills they possess and their demeanors, which, ultimately help to initiate the process of international migration.

\section{Discussion and Recommendations}

The case study I present in this dissertation highlights the interconnectedness that exists between a variety of actors in an ever-evolving globalizing world. As I tried to demonstrate in this manuscript, the process of globalization does not explicitly correspond to the market behaviors of multinational corporations expanding to less 
developed countries in search for cheaper labor and weak environmental regulations. The process also does not correspond to cultural views of globalization as a process where borders are broken down by the increased spread of trends, business, fashion, or information across international borders. Instead, as I have argued, globalization is a discontinuous process which takes specific characteristics due to the attitudes, behaviors, and characteristics of a variety of structural, institutional and political arrangements that can vary according to the products made, and localities where they are produced. Within the context of a growing neoliberal economic and political global environment, thus, my findings of the conditions of plant nursery production in the State of Florida demonstrate that a group of well-organized business entrepreneurs have situated themselves in positions of power and effectively created an institutional regime along other industry professional insiders and political elites. This form of interaction has a variety of consequences for trade and migration, which, are planned and executed at a localized level, but directly take on international and global connotations.

In the State of Florida, owners and employers in the plant nursery industry have been able to successfully resist global trends in free trade and instead operate in a protected market. They have done this by using an ideology supported by science and by the explicit support of politicians. In this particular case, thus, the neoliberal ideology has been implemented through a set of policies that while keeping small and middle range business alive, has become dependent on a seemingly endless supply of marginal low-wage, immigrant workers. This market behavior also creates intense competition from local producers who often violate the few legal restraints they have (e.g., the low number of wage violation investigations by the federal $\mathrm{DOL}$ ) in order to get ahead.

Still, the relationship between the protected nature of the industry and dependence to low wage workers is not all too clear. Especially, since their protected status could 
indicate that the wages could be higher. In essence, it seems that the necessarily low wage nature of the industry grows from a confluence of factors that include the exemption of agriculture from the NLRA; the rural nature of most such employments, which also make organizing harder; the availability of a low wage workforce, which is overwhelmingly immigrant and poor; the unskilled or semi-skilled nature of the work, and; the political clout of the industry over politicians representing these business interests. It is important, however, to also take into consideration the values and expectations of Florida plant nursery operators in regards to their labor force. As Hollander (2008) demonstrates, the presence of immigrant workers in the sugar fields of the State of Florida responded to direct efforts of entrepreneurs and policy makers to circumvent the use of local Black and poor White laborers, and to secure a docile labor force that was willing to work for low wages and without complaining too much for poor working conditions.

For the workers the conditions within the global market place are quite different. Again, neoliberal trends for them are clearly at work, keeping borders open for goods and for service workers at the high end of the labor market, but placing costs and dangers on workers who have little recourse to protect their interests. For many of the workers, free trade along with civil war and violence means they can't make a living in their home country. They can opt to come to the US, but only at their own cost and risk, and once here they can work for low wages in often unsafe conditions and even then employers can exploit them beyond the limits of the law and with limited liability.

At an institutional level, this case study provides an early attempt to better understand the nature and structure of ornamental agriculture in the State of Florida. As I argued earlier, only a handful of economic reports on this industry are available and to my knowledge none address the interactions and market behaviors of industry players. 
Clearly, more research is needed to better understand the roles and conditions of market players, including the demographic, economic, and employment characteristics of the labor force. In addition, there is a lack of academic analysis of organizing and of the community organizations that perform a variety of in-valuable services to the workers. At a broader level, there is a need to further study the roles that traditional firms play in larger processes of globalization, including the way in which strongly rooted local business practices affect the conditions of market players across international borders. 


\section{LIST OF REFERENCES}

Aguilera, Elizabeth. "City Works on Day-Laborer Wage Protection Many of the Victims Are Immigrants Who Are Cheated out of Their Pay. A Denver Proposal Would Make Wage Theft a Local Crime." Denver Post, November.16, 2005, B1.

Aguilera, Michael B., and Douglas S. Massey. "Social Capital and the Wages of Mexican Migrants: New Hypotheses and Tests." Social Forces 82, no. 2 (2003): 671-701.

Angee, Alejandro and Cynthia S. Hernandez. "Seeds of Justice: Combating wage theft among South Florida's plant nursery workers." Paper sponsored by The Reasearch Institute on Social and Economic Policy, Florida International University, October 1, 2007. Accessed October 7, 2012. http://www.risep-fiu.org/2007/10/planting-seedsof-justice/

Apple, Lauri. "The Theft of Wages Is Sin: Fighting for Migrant Workers." The Austin Chronicle, December 27, 2002. Accessed October 5, 2012. http://www. austinchronicle.com/news/2002-12-27/115732/

Avila, Oscar. "Day Laborers' Tough Choice: Rights or Job." Chicago Tribune, December 28, 2005. Accessed October 5, 2012. http://articles.chicagotribune.com/2005-1228/news/0512280164_1_day-laborers-latino-union-immigrants

Basch, Linda G., Nina Glick Schiller, and Cristina Szanton Blanc. Nations Unbound: Transnational Projects, Postcolonial Predicaments, and Deterritorialized Nation States. Langhorne, Pa: Gordon and Breach, 1994.

Bernard, Bush. "Suit Filed on Behalf of Migrants." The Tennessean March 6, 2006 Accessed October 6, 2012. http://pqasb.pqarchiver.com/tennessean/access/ 1770450391. html?FMT=ABS\&FMTS=ABS:FT\&date=Mar+6\%2C+2006\&author=BU $S H+B E R N A R D \& p u b=T h e+$ Tennessean\&edition $=\&$ startpage $=E .1 \& d e s c=$ Suit + filed + on+behalf+of+migrants

Bobo, Kimberley A. Wage Theft in America: A Prevention Manual. New York: The New Press, 2009.

Bonacich, Edna, and John Modell. The Economic Basis of Ethnic Solidarity: Small Business in the Japanese American Community. Berkeley: University of California Press, 1980.

Boswell, Thomas D., June Nogel, Rob Paral, and Richard Langendorf. Facts about Immigration: Asking 'Six Big Questions' for Florida and Miami-Dade County. Gainesville, FL: Bureau of Economic and Business Research, University of Florida, 2001.

Bender, Daniel E., and Richard A. Greenwald. Sweatshop USA : The American Sweatshop in Historical and Global Perspective. New York: Routledge, 2003. 
Blau, Joel. Illusions of Prosperity : America's Working Families in an Age of Economic Insecurity. New York: Oxford University Press, 1999.

Bonacich, Edna, and Richard P. Appelbaum. Behind the Label: Inequality in the Los Angeles Apparel Industry. Berkeley: University of California Press, 2000.

Brennan Center for, Justice. "Do New Yorkers Know the Minimum Wage? Results from a Spot Survey of Employers and Workers in New York City." In Economic Policy Brief, 2. New York: New York University School of Law, 2006.

Bronfenbrenner, Kate "Uneasy Terrain: The Impact of Capital Mobility on Workers, Wages, and Union Organizing." Submitted to the U.S. Trade Deficit Review Commission, 2000.

Bronfenbrenner, Kate, and Robert Hickey. "Changing to Organize: A National Assesment of Union Strategies." In Rebuilding Labor: Organizing and Organizers in the New Union Movement, edited by Ruth Milkman and Kim Voss, 17-61. Ithaca, NY: Cornell University Press, 2004.

Burfisher, Mary E., Sherman Robinson, and Karen Thierfelder. "The Impact of NAFTA on the United States." The Journal of Economic Perspectives 15, no. 1 (2001): 12544.

Calavita, Kitty. Immigrants at the Margins: Law, Race, and Exclusion in Southern Europe. New York: Cambridge University Press, 2005.

_- Inside the State: The Bracero Program, Immigration, and the I.N.S, After the Law. New York: Routledge, 1992.

Campbell, Al. "The Birth of Neoliberalism in the United State: A Reorganisation of Capitalism." In Neoliberalism: A Critical Reader, edited by Alfredo Saad-Filho and Deborah Johnston, 187-98. London; Ann Arbor, MI: Pluto Press, 2005.

Canterbury, Dennis C. Neoliberal Democratization and New Authoritarianism. Aldershot, Hants, England; Burlington, VT: Ashgate, 2005.

Castro, Max J. Free Markets, Open Societies, Closed Borders? : Trends in International Migration and Immigration Policy in the Americas. Coral Gables, FL: North-South Center Press, 1999.

Center, Southern Poverty Law. "Beneath the Pines: Stories of Migrant Tree Planters." Published by The Immigrant Justice Project. Montgomery, AL: Southern Poverty Law Center, 2006.

Chiswick, Barry R., and W.E. Upjohn Institute for Employment Research. Illegal Aliens: Their Employment and Employers. Kalamazoo, MI: W.E. Upjohn Institute for Employment Research, 1988. 
Clarke, Simon. "The Neoliberal Theory of Society." In Neoliberalism: A Critical Reader, edited by Alfredo Saad-Filho and Deborah Johnston, 50-9. London; Ann Arbor, MI: Pluto Press, 2005.

Comaroff, Jean, and John L. Comaroff. Millennial Capitalism and the Culture of Neoliberalism. Durham, NC: Duke University Press, 2001.

Craypo, Charles. "The Decline in Union Bargaining Power." In U.S. Labor Relations, 1945-1989: Accommodation and Conflict, edited by Bruce Nissen, 3-44. New York: Garland, 1990.

Dash, Robert C. "Strawberry Farmworker Organizing." ZMagazine, 1995.

Delgado Wise, Raul, and James M. Cypher. "The Strategic Role of Mexican Labor under NAFTA: Critical Perspectives on Current Economic Integration." The ANNALS of the American Academy of Political and Social Science 610, no. 1 (2007): 120-42.

Department of Labor, Employment and Training Administration, National Agricultural Workers Survey, Public Access Data, Fiscal Years 2002-2006. Accessed October 7, 2012. http://www.doleta.gov/agworker/naws.cfm

DeWind, Josh, and Philip Kasinitz. "Everything Old is New Again? Processes and Theories of Immigrant Incorporation." International Migration Review 31, no. 4 (1997): 1096-111.

Dole, Daniel Kerr and Chris. "Challenging Exploitation and Abuse: A Study of the Day Labor Industry in Cleveland." Report prepared for the Cleveland City Council, Sptember 4, 2001. Accessed October 7, 2012. http://www.popcenter.org/ problems/day_labor_sites/PDFs/Kerr\&Dole_2001.pdf

Dow, Mark. "Unchecked Power against Undesirables. Haitians, Mariel Cubans, and Guantanamo." In Keeping out the Other, edited by David C. Brotherton and Philip Kretsedemas, 29-43. New York: Columbia University Press, 2008.

Dumenil, Gerard, and Dominique Levy. "The Neoliberal (Counter-) Revolution." In Neoliberalism: A Critical Reader, edited by Alfredo Saad-Filho and Deborah Johnston, 9-19. London; Ann Arbor, Ml: Pluto Press, 2005.

Egelko, Bob. "Bosses off the Hook for Unpaid Overtime." San Francisco Chronicle, August 12, 2005. Accessed October 6, 2012. http://www.sfgate.com/business/ article/Bosses-off-the-hook-for-unpaid-overtime-In-2648689.php

Evans, Edward A. "Potential Problems Facing the U.S. Nursery Industry." Department of Food and Resource Economics, Florida Cooperative Extension Service, UF/IFAS, University of Florida, Gainesville, FL. August 2004. Accessed October 6, 20120. http://edis.ifas.ufl.edu/pdffiles/FE/FE49100.pdf 
Evans, Edward A. and John J. VanSickle. "The Dilemma of Safer and Freer Trade: The Case of the U.S. Nursery Industry." International Agricultural Trade and Policy Center, Policy Brief Series, October 2003. Accessed October 6, 2012. http:// www.fred.ifas.ufl.edu/iatpc/archive/PBTC_03-12.pdf.

Faist, Thomas. The Volume and Dynamics of International Migration and Transnational Social Spaces. Oxford; New York: Clarendon Press: Oxford University Press, 2000.

Fernandez-Kelly, Patricia. "NAFTA and Beyond: Alternative Perspectives in the Study of Global Trade and Development." The ANNALS of the American Academy of Political and Social Science 610 (2007): 6-19.

Fernandez-Kelly, Patricia, and Douglas S. Massey. "Borders for Whom? The Role of NAFTA in Mexico-U.S. Migration." The ANNALS of the American Academy of Political and Social Science 610 (2007): 98-118.

Ferreira, Rui. "Life in Miami's Underground It Is an Economic Realm Bereft of Rules, Taxes -- and Security." Miami Herald, the, September 6, 1998, final edition, 1F.

Fields, Gregg. "On the Edge: Untaxed and Unregulated Businesses Bloom on the Fringes of the Economy." Miami Herald, The, April 18, 1988, final edition, 7BM.

Fine, Janice. Worker Centers: Organizing Communities at the Edge of the Dream. Ithaca: Cornell University Press, 2006.

Gamboa, Erasmo. Mexican Labor and World War II: Braceros in the Pacific Northwest, 1942-1947. Austin: University of Texas Press, 1990.

Gélinas, Jacques, and Raymond Robitaille. Juggernaut Politics: Understanding Predatory Globalization. London; New York: Zed Books, 2003.

Glazer, Nathan, and Daniel P. Moynihan. Beyond the Melting Pot; the Negroes, Puerto Ricans, Jews, Italians, and Irish of New York City. 2d ed., Cambridge: M.I.T. Press, 1970.

Glick Schiller, Nina. "Who Are These Guys? A Transnational Reading of the U.S. Immigrant Experience." In Identities on the Move: Transnational Processes in North America and the Caribbean Basin, edited by Liliana R. Goldin, viii, 279 p. Albany, NY: University of Texas Press, 1999.

Glyn, Andrew. Capitalism Unleashed: Finance Globalization and Welfare. Oxford; NY: Oxford University Press, 2006.

Goldin, Liliana R. Identities on the Move: Transnational Processes in North America and the Caribbean Basin. Albany, NY: University of Texas Press, 1999.

Gonzalez, Daniel. "Phoenix Treats Cheating Laboresrs as a Criminal Act." Arizona Republic, The, February 11, 2006 
Gordon, Milton Myron. Assimilation in American Life: The Role of Race, Religion, and National Origins. New York: Oxford University Press, 1964.

Green, Frank. "Garment Worker Abuses Continuing, Group Says - Wage, Overtime Claims up Fourfold since 1998." San Diego Union-Tribune, September 29, 2005, C1.

Green, Nancy L. "Fashion, Flexible Specialization, and the Sweatshop: A Historical Problem." In Sweatshop USA: The American Sweatshop in Historical and Global Perspective, edited by Daniel E. Bender and Richard A. Greenwald, 37-56. New York: Routledge, 2003.

Greenhouse, Steven. "Altering of Worker Time Cards Spurs Growing Number of Suits," New York Times, April 4, 2004. Accessed October 6, 2012. http://www.nytimes.com /2004/04/04/us/altering-of-worker-time-cards-spurs-growing-number-ofsuits.html?pagewanted=all\&src=pm

Greider, William. One World, Ready or Not: The Manic Logic of Global Capitalism. New York: Simon \& Schuster, 1997.

Grenier, Guillermo J. Inhuman Relations: Quality Circles and Anti-Unionism in American Industry, Labor and Social Change. Philadelphia: Temple University Press, 1988.

Griffith, David Craig. American Guestworkers: Jamaicans and Mexicans in the U.S. Labor Market. University Park, PA: Pennsylvania State University Press, 2006.

__Jones's Minimal: Low-Wage Labor in the United States. Albany: State University of New York Press, 1993.

Hafetz, David. "Unpaid Workers Speak up, and Police Listen, Act." Austin AmericanStatesman, May 27, 2003, news section.

Hall, Charles, Alan Hodges, and John Haydu. "Economic Impacts of the Green Industry in the United States." Final report to the USDA-Forest Service, National Urban and Community Forestry Advisory Committee, June 2005, Accossed October 8, 2012. www.utextension.utk.edu/hbin/greenimpact.html.

Harvey, David. A Brief History of Neoliberalism. New York: Oxford University Press, 2005.

—. "Neoliberalism as Creative Destruction." The ANNALS of the American Academy of Political and Social Science 610 (2007): 21-44.

Hayes, Helene. U.S. Immigration Policy and the Undocumented: Ambivalent Laws, Furtive Lives. Westport, CT: Praeger, 2001.

Heath, Jonathan. "The Impact of Mexico's Trade Liberalization." In The Post-NAFTA Political Economy: Mexico and the Western Hemisphere, edited by Carol Wise, 171-200. University Park, PA: The Pennsylvania state University Press, 1998. 
Hing, Bill Ong. Defining America through Immigration Policy. Philadelphia: Temple University Press, 2004.

Hodges, Alan W. and John J. Haydu. "Structure and Market Organization of Florida's Landscape Plant Industry." Journal of Environmental Horticulture 10(1): 32-36. March 1992.

_- . "Economic Impacts of the Florida Environmental Horticulture Industry in 2005" Sponsored Project Report to the Florida Nursery, Growers and Landscape Association, Gainsville, FL: University of Florida, Institute of Food and Agricultural Sciences, 2006. Accessed October 8, 2012. http://economicimpact.ifas.ufl.edu

—. "Wages and Benefits in the Florida Landscape Industry." Food and Resource Economics Department, Florida Cooperative Extension Service, Institute of Food and Agricultural Sciences, University of Florida, Gainesville, FL. December 2008.

Hodges, Alan W. and W. David Mulkey. "Economic Impacts of Agriculture and Natural Resource Industries in Florida 2003." Extension document FE627, University of Florida/IFAS, Gainesville, FL. 2006. Accessed October 12, 2012.http:// edis.ifas.ufl.edu/fe627.

—. "Characteristics of the Florida Nursery Industry: 2003-04." Food and Resource Economics Department, Florida Cooperative Extension Service, Institute of Food and Agricultural Sciences, University of Florida, Gainesville, FL, 2005.

Hunsberger, Brent. "Six Oregon Restaurants Accused of Wage Abuses." Oregonian, The, February 3, 2006, sunrise edition, C01.

Jerardo, A. "Floriculture and Nursery Crops Situation and Outlook.FLO-20055." USDAERS, Washington, DC, June 2005.

Jerardo, A. "Floriculture and Nursery Crops Yearbook. FLO-2007." USDA-ERS, Washington,DC, Sept 2007.

Johnson, Paul H. "Exploitation of Waitresses Alleged - ACLU: Fairview eatery abused, humiliated pair." Record, The, November 1, 2005, all editions, L03.

Kandel, William, and Douglas S. Massey. "The Culture of Mexican Migration: A Theoretical and Empirical Analysis." Social Forces 80, no. 3 (2002): 981-1004.

Kingsolver, Ann E. NAFTA Stories: Fears and Hopes in Mexico and the United States. Boulder: L. Rienner Publishers, 2001.

Kretsedemas, Philip, and David C. Brotherton. "Open Markets, Militarized Borders?" In Keeping out the Other, edited by David C. Brotherton and Philip Kretsedemas, 1-28. New York: Columbia University Press, 2008. 
Kritz, Mary M., and Douglas T. Gurak. "Immigration and a Changing America." In The American People, edited by Ellen Carnevale, Mary M. Kent and Allison Tarmann, i,43. New York: Russell Sage Foundation, 2004.

Lamphere, Louise, Alex Stepick, and Guillermo J. Grenier. Newcomers in the Workplace: Immigrants and the Restructuring of the U.S. Economy. Philadelphia: Temple University Press, 1994.

Lashuay, Nan Burgel Barbara J. Harrison Robert Israel Leslie Chan Jacqueline Cusic Catherine Chao Pun Jane Fong Ken Shin Young. "We Spend Our Days Working in Pain: A Report on Workplace Injuries in the Garment Industry." Asian Immigrant Women Workers Clinic, Oakland, California, 2002.

Lee, Henry K. "Wal-Mart Loses Suit Over Lunches / Oakland Jury Orders Giant Retailer to Pay Workers \$172 Million." San Francisco Chronicle, December 23, 2005.

Accessed October 6, 2012. http://www.sfgate.com/news/article/Wal-Mart-loses-suitover-lunch-breaks-Oakland-2572757.php

Leisink, Peter. Globalization and Labour Relations. Cheltenham, UK; Northampton, Ma: E. Elgar, 1999.

Light, Donald W. "Globalizing Restricted and Segmented Markets: Challenges to Theory and Values in Economic Sociology." The ANNALS of the American Academy of Political and Social Science 610 (2007): 232-45.

Light, Ivan Hubert, and Edna Bonacich. Immigrant Entrepreneurs: Koreans in Los Angeles, 1965-1982. Berkeley: University of California Press, 1988.

Lucas, Robert E.B. "International Migration: Economic Causes, Consequences and Evaluation." In Global Trends in Migration: Theory and Research on International Population Movements, edited by Mary M. Kritz, Charles B. Keely and Silvano M. Tomasi, 279-97. Staten Island, NY: Center for Migration Studies, 1981.

MacEwan, Arthur. "Neoliberalism and Democracy: Market Power Vs. Democratic Power." In Neoliberalism: A Critical Reader, edited by Alfredo Saad-Filho and Deborah Johnston, 170-6. London; Ann Arbor, MI: Pluto Press, 2005.

—. Neo-Liberalism or Democracy? Economic Strategy, Markets, and Alternatives for the 21st Century. London; New York: Zed Books, 1999.

Mahler, Sarah J. American Dreaming: Immigrant Life on the Margins. Princeton, N.J: Princeton University Press, 1995.

Margolies, Dan. "Suit Vs. Wal-Mart Ruled a Class Action." Kansas City Star, November 2, 2005, C1.

Marks, Alexandra. "Cracking Down on Employers Who Ignore Wage Laws." Christian Science Monitor, The, June 3, 2005. Accessed October 6, 2012. http:// www.csmonitor.com/2005/0603/p01s04-usec.html 
Martin, Philip L. Promise Unfulfilled: Unions, Immigration, and the Farm Workers. Ithaca: Cornell University Press, 2003.

Marx, Karl, and Friedrich Engels. The Marx-Engels Reader. Edited by Robert C. Tucker. 2d ed. New York: Norton, 1978.

Massey, Douglas S., Jorge Durand, and Nolan J. Malone. Beyond Smoke and Mirrors: Mexican Immigration in an Era of Economic Integration. New York: Russell Sage Foundation, 2002.

Milkman, Ruth. "New Workers, New Labor, and the New Los Angeles." In Unions in a Globalized Environment: Changing Borders, Organizational Boundaries, and Social Roles, edited by Bruce Nissen, 103-29. Armonk, NY: M.E. Sharpe, 2002.

_- Organizing Immigrants: The Challenge for Unions in Contemporary California. Ithaca, NY: ILR Press, 2000.

- - L. A. Story: Immigrant Workers and the Future of the U.S. Labor Movement. New York, NY: R. Sage Foundation, 2006.

Milkman, Ruth, and Kim Voss. Rebuilding Labor: Organizing and Organizers in the New Union Movement. Ithaca, NY: Cornell University Press, 2004.

Miller, George. "Everyday Low Wages: The Hidden Price We All Pay for Wal-Mart." A Report by the Democratic Staff of the Committee on Education and the Workforce, U.S. House of Representatives, February 16, 2004.

Moran, Theodore H. Beyond Sweatshops: Foreign Direct Investment and Globalization in Developing Countries. Washington, DC: Brookings Institution Press, 2002.

Morris, Ruth. "As Construction Business Climbs, Wages Are Falling." South Florida SunSentinel, August 14, 2005, Broward metro edition, 1 A.

Munck, Ronaldo. "Neoliberalism and Politics, and the Politics of Neoliberalism." In Neoliberalism: A Critical Reader, edited by Alfredo Saad-Filho and Deborah Johnston, 60-9. London; Ann Arbor, MI: Pluto Press, 2005.

Munck, Ronaldo, and Peter Waterman. Labour Worldwide in the Era of Globalization: Alternative Union Models in the New World Order. New York: St. Martin's Press, 1999.

Ness, Immanuel. Immigrants, Unions, and the New U.S. Labor Market. Philadelphia: Temple University Press, 2005.

Neumann, Rachel. "Cutting out the Pattern Why New York's Garment Industry Has a Vested Interest in Improving Sweatshop Conditions." City Limits, June 1, 2001. Accessed October 8, 2012. http://www.citylimits.org/news/article_print.cfm? article_id=2059 
Nissen, Bruce. U.S. Labor Relations, 1945-1989: Accommodation and Conflict. New York: Garland, 1990.

-. Unions in a Globalized Environment: Changing Borders, Organizational Boundaries, and Social Roles. Armonk, NY: M.E. Sharpe, 2002.

—. Which Direction for Organized Labor? Essays on Organizing, Outreach, and Internal Transformations. Detroit: Wayne State University Press, 1999.

_- Employment Practices and Working Conditions in the Building Services Industry in Miami-Dade County, Florida." Report by the Social Institute on Social and Economic Policy, Florida International University 2004.

Nissen, Bruce, and Guillermo Grenier. "Unions and Immigrants in South Florida: A Comparison." In Unions in a Globalized Environment: Changing Borders, Organizational Boundaries, and Social Roles, edited by Bruce Nissen, 130-60. Armonk, NY: M.E. Sharpe, 2002.

Otero, Gerardo. Neoliberalism Revisited: Economic Restructuring and Mexico's Political Future. Boulder, CO: Westview Press, 1996.

Piazza, James A. Going Global: Unions and Globalization in the United States, Sweden, and Germany. Lanham, MD: Lexington Books, 2002.

Pemberton, Pam. "Wal-Mart Sued for Wage Abuse" Pueblo Chieftain, The, December 23, 1998.

Piore, Michael J. Birds of Passage: Migrant Labor and Industrial Societies. Cambridge; New York: Cambridge University Press, 1979.

Portes, Alejandro. "Immigration Theory for a New Century: Some Problems and Opportunities." International Migration Review 31, no. 4 (1997): 799-825.

_- . "Modes of Structural Incorporation and Present Theories of Labor Immigration." In Global Trends in Migration: Theory and Research on International Population Movements, edited by Mary M. Kritz, Charles B. Keely and Silvano M. Tomasi, 27997. Staten Island, NY: Center for Migration Studies, 1981.

_- "Social capital: its origins and applications in modern sociology." Problemas e Praticas 33 (2000): 133-58.

Portes, Alejandro, and Patricia Landolt. "The Downside of Social Capital." The American Prospect, 26 (1996): 18-94.

Portes, Alejandro, and Rubén G. Rumbaut. Immigrant America: A Portrait. 3rd ed. Berkeley: University of California Press, 2006. 
Portes, Alejandro, and Julia Sensenbrenner. "Embeddedness and Immigration: Notes on the Social Determinants of Economic Action." American Journal of Sociology 98, no. 6 (1993): 1320-50.

Portes, Alejandro, and Alex Stepick. City on the Edge: The Transformation of Miami. Berkeley: University of California Press, 1993.

Portes, Alejandro, and John Walton. Labor, Class, and the International. New York: Academic Press, 1981.

Quinones, Sam. "Many of Katrina's Migrant Workers Go Unpaid." Los Angeles Times, September 11,2006. Accessed October 6, 2012. http://articles.latimes.com/ 2006/sep/11/nation/na-contractors11

Radice, Hugo. "Neoliberal Globalisation: Imperialism without Empires?" In Neoliberalism: A Critical Reader, edited by Alfredo Saad-Filho and Deborah Johnston, xi, 268 p. London; Ann Arbor, MI: Pluto Press, 2005.

Rainsberger, Paul. "The Constraints of Public Policy: Legal Perspectives on the Decline of the Labor Movement since World War ii." In U.S. Labor Relations, 1945-1989: Accommodation and Conflict, edited by Bruce Nissen, 91-136. New York: Garland, 1990.

Randall, Stephen J., William W. Konrad, and Sheldon Silverman. North America without Borders? Integrating Canada, the United States, and Mexico. Calgary: University of Calgary Press, 1992.

Rapley, John. Globalization and Inequality: Neoliberalism's Downward Spiral. Boulder, CO: Lynne Rienner, 2004.

Renford, Rochelle. "Picking a Fight." Orlando Weekly, June 14, 2001. Accessed October 6, 2012. http://www2.orlandoweekly.com/news/story.asp?id=2269.

Riccardi, Nicholas. "New Denver Law Aims to Ensure Pay for Immigrant Day Laborers." LA Times, January 10, 2006. Accessed October 6, 2012. http://articles.latimes.com/ 2006/jan/03/nation/na-wages3

Robbins, Richard H. Global Problems and the Culture of Capitalism. 2nd ed. Boston, MA: Allyn \& Bacon, 2001.

Rosen, Ellen Israel. Making Sweatshops: The Globalization of the U.S. Apparel Industry. Berkeley: University of California Press, 2002.

Saad-Filho, Alfredo, and Deborah Johnston. Neoliberalism: A Critical Reader. London; Ann Arbor, Ml: Pluto Press, 2005.

Sassen, Saskia. Globalization and Its Discontents: Essays on the New Mobility of People and Money. New York: New Press, 1998. 
- The Mobility of Labor and Capital: A Study in International Investment and Labor Flow. Cambridge, England; New York: Cambridge University Press, 1988.

__. "Transnational Economics and National Migration Policies." In Free Markets, Open Societies, Closed Borders? Trends in International Migration and Immigration Policy in the Americas, edited by Max J. Castro, 7-32. Coral Gables, Fla. Boulder, CO: North-South Center Press; Distributed by Lynne Rienner Publishers, 1999.

Schmitter Heisler, Barbara. "The Sociology of Immigration." In Migration Theory: Talking Across Disciplines, edited by Caroline Brettell and James Frank Hollifield, 77-96. New York: Routledge, 2000.

Seybold, Peter. "American Labor at the Crossroads. Political Resurgence or Continued Decline?" In U.S. Labor Relations, 1945-1989 : Accommodation and Conflict, edited by Bruce Nissen, 45-90. New York: Garland, 1990.

Shaikh, Anwar. "The Economic Mythology of Neoliberaism." In Neoliberalism: A Critical Reader, edited by Alfredo Saad-Filho and Deborah Johnston, 41-9. London; Ann Arbor, Ml: Pluto Press, 2005.

Shelley, Toby. Exploited: Migrant Labour in the New Global Economy. London; New York: Zed Books, 2007.

Stark, Oded. The Migration of Labor. Cambridge, MA: B. Blackwell, 1991.

Stephen, Lynn. Transborder Lives: Indigenous Oaxacans in Mexico, California, and Oregon. Durham: Duke University Press, 2007.

Stepick, Alex, Guillermo J. Grenier, Max Castro, and Marvin Dunn. This Land Is Our Land: Immigrants and Power in Miami. Berkeley: University of California Press, 2003.

Stepick, Alex. Pride against Prejudice: Haitians in the United States. Boston: Allyn and Bacon, 1998.

Stiglitz, Joseph E. Globalization and Its Discontents. New York: W.W. Norton, 2002.

Tabb, William K. The Amoral Elephant: Globalization and the Struggle for Social Justice in the Twenty-First Century. New York: Monthly Review Press, 2001.

Theodore, Nikolas. "A Fair Day's Pay? Homeless Day Laborers in Chicago." Report by the Center for Urban Economic Development, University of Illinois at Chicago, 2000.

Tsing, Anna Lowenhaupt. Friction: An Ethnography of Global Connection. Princeton, N.J: Princeton University Press, 2005.

Tucker-Welch, Suzette. "The State of Working Immigrants in Colorado." Report by the Colorado Fiscal Policy Institute, March 2004. 
USDA. "Floriculture Crops 2006 Summary." U.S. Department of Agriculture-National Agricultural Statistics Service, 2007.

USDA. Census of Agriculture, 2007. Florida State and County Data, vol. 1, Geographic Area Series, Part 51. U.S. Department of Agriculture-National Agricultural Statistics Service. Washington, DC, February 2009.

Valenty, Richard. "Council to Talk Wage Theft." Colorado Daily, January 15, 2006

Valenzuela, Abel Jr Theodore Nik Melendez Edwin Gonzalez Ana Luz. "On the Corner: Day Labor in the United States." January, 2006. Accessed October 7, 2012. http:// www.sscnet.ucla.edu/issr/csup/uploaded_files/Natl_DayLabor-On_the_Corner1.pdf

Valenzuela, Abel Jr., Ana Luz Gonzalez, Nik Theodore and Edwin Melendez. "Pursuit of the American Dream: Day Labor in the Greater Washington D.C. Region." Report by the Center for the Study of Urban Poverty. University of California, Los Angeles 2005.

Valenzuela, Abel, Jr. "Day Laborers in Southern California: Preliminary Findings from the Day Labor Survey." Report by the Center for the Study of Urban Poverty. University of California, Los Angeles, 1999.

Vázquez, Castillo Maria T. Land Privatization in Mexico: Urbanization, Formation of Regions and Globalization in Ejidos. New York: Routledge, 2004.

Waldinger, Roger David, and Michael Ira Lichter. How the Other Half Works: Immigration and the Social Organization of Labor. Berkeley, CA: University of California Press, 2003.

Waldinger, Roger, and Claudia Der-Martirosian. "Immigrant Workers and American Labor: Challenge or Disaster." In Organizing Immigrants: The Challenge for Unions in Contemporary California, edited by Ruth Milkman, 49-80. Ithaca, NY: ILR Press, 2000.

Walsh, Jim. "Immigrants Often Go Unpaid." Arizona Republic, The, February 23, 2006. Accessed October 6, 2012. http://www.azcentral.com/arizonarepublic/mesa/ articles/0223mr-immigrants0223Z11.html?nclick_check=1 


\section{APPENDICES: APPENDIX A. DEFINITIONS AND DIVERSITY OF CROPS}

\section{Floriculture Crops}

Bedding and garden plants: Annual or biennial finished flowering plants intended for seasonal outdoor use. Among the major annuals are begonias, geraniums, impatiens, marigolds, pansy/viola, and petunias. This category also includes vegetable-type ornamental plants, vegetable transplants for garden use, and herbaceous perennials, but exclude commercial vegetable plants. The plants are marketed as flats, pots, or hanging baskets.

Cut foliage or greens: Cultivated ornamental stems, branches, or leaves grown as filler and foliage for cut flower arrangements and bouquets. Leatherleaf ferns, largely grown in Florida, are a major cut green.

Cut flowers: Blossoms from flowering plants sold as stems, bunches, or arrangements; the flowers may be fresh, dried, or preserved. The major commercial varieties include standard carnations, roses, pompon chrysanthemums, gladioli, tulips, orchids, lilies, alstroemeria, delphinium and larkspur, gerbera daisies, iris, lisianthus, and snapdragons. Floriculture crops: Ornamental plants without woody stems, including annual and perennial bedding and garden plants, cut flowers, cut cultivated greens, potted flowering plants, indoor foliage plants, and unfinished propagative material. All other ornamental plants are classified as nursery crops.

Foliage plants: Finished plants in pots or hanging baskets for indoor or patio use; they are classified as floriculture crops. Woody foliage plants intended for outdoor or landscape use are classified as nursery crops. Include ficus, ivy, cacti, ferns, palms, succulents, and indoor/patio shrubs, trees, and vines.

Greenhouse crops: Crops grown under covered protection, including floral, foliage, and vegetable plants (largely tomatoes), unfinished plants, transplant seedlings, bulbs, 
turfgrass sod, aquatic and hydroponic plants, cultivated mushrooms, herbs, and seeds. Grower sales receipts from greenhouse crops include vegetable and fruit transplants for commercial production. Some nursery crops are grown in greenhouses before sale or transplant.

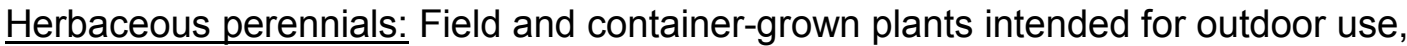
including hardy/garden chrysanthemums, hosta, and other herbaceous perennials. Unlike annuals, perennials live and bloom for many years; they are dormant in the winter. Unfinished plants are excluded.

Nursery crops: Finished ornamental plants and trees with woody stems, including broadleaf evergreens, coniferous evergreens, deciduous shade trees, deciduous flowering trees, deciduous shrubs and other ornamentals, fruit and nut plants intended for outdoor and landscape use, cut and live Christmas trees, and propagation material or lining-out stock. Also include ornamental vines, turfgrass sod, and other groundcovers. Crops are sold as "balled in burlap," bare root, or are container-grown.

Ornamental crops: Also known as environmental horticulture or green crops. All floriculture and nursery plants, shrubs, trees, and grasses for outdoor and indoor use are classified as ornamental. Their purpose is to beautify, decorate, or enhance the environment, but are not cultivated for food. They include nursery stock and propagative material such as bulbs, cuttings and slips of plants, seedlings, and seed plants grown in greenhouses but exclude plants intended for commercial food production such as vegetables.

Potted flowering plants: Plants intended only for indoor or patio use, including plants grown from bulbs. Plants intended for landscape use are excluded. Include African violets, florist azaleas, florist chrysanthemums, Easter lilies, orchids, poinsettias, roses, and spring bulbs (tulips, hyacinths, daffodils/narcissus, other lilies). Other potted plants 
include anthurium, begonia, carnation, hibiscus, hydrangea, cyclamen, kalanchoe, and gardenia.

Production area: The gross physical space used for commercial propagation of floriculture plants, including aisles and walkways, in open ground (field) or covered by greenhouses made of glass, fiberglass, film plastic, or shade and temporary cover. Excludes non-ornamental crop growing areas, such as fruit and vegetable farms, sod, or tree and shrub nurseries.

Propagative material: Includes cuttings, liners, plug seedlings, prefinished plants, or tissue cultured plantlets, and unfinished plants sold to other growers for further growing. Excludes seeds, bulbs, tubers, rhizomes, or corms grown for sale to bulb forcers and gardeners. Also excludes transplants for commercial production such as vegetable, strawberry, and tobacco plants.

Wholesale value of sales: The value of all crops grown then sold by their growers on a gross wholesale basis before deductions for sales commissions, transportation costs, and other similar charges. The percentage of sales at wholesale is the crop portion not sold at retail or marketed directly to the final consumer. It is computed as the product of the average wholesale price and the total quantity of crops sold by the producer at wholesale.

\section{Nursery Crops}

Broadleaf evergreens: Broadleaf trees and plants that retain their leaves year round such as azaleas, boxwood, holly, and rhododendron.

Christmas trees, cut and to be cut: Evergreen trees grown to be sold as cut Christmas trees. Balled and burlapped trees are included in coniferous evergreens.

Coniferous evergreens: Cone-bearing trees and plants that retain their needle-like or scale-like leaves year round such as arborvitae, cedar, fir, pine, and spruce, including 
balled and burlapped Christmas trees. Christmas trees grown for cutting are not included in this category.

Deciduous flowering trees: Ornamental trees that lose their leaves during the cold months and are grown and known for their flowering ability such as dogwood, hawthorn, magnolia, and redbud.

Deciduous shade trees: Trees that lose their leaves during the cold months and are primarily used for shade such as ash, birch, maple, oak, and willow.

Deciduous shrubs: Plants and trees that lose their foliage during the cold Fruit and nut plants: Plants and trees primarily used for fruit and nut production, including citrus and deciduous fruit trees, nut trees, grapevines, and small fruit plants such as blueberries and grapevines. Strawberry plants for home use are included in this category. Strawberry plants for commercial producers are included in the transplants category.

Ornamental grasses: Include grasses (for landscape or garden use), sedges, and reeds. Sod, turf, and range grasses are specifically excluded from this category.

Other woody ornamentals, vines, and ground covers: Include climbing clematis, ground covers, and other vines.

Palms: Plants of the family arecaceae (palmae) used for outdoor landscaping. Palms sold for indoor or patio use are not included in this category.

Propagative nursery materials or lining-out stock: Unfinished plants of the nursery crops in this survey to be further grown (such as lining-out stock, root stock, rooted cuttings, seedlings, and tissue-cultured plantlets) by other growers. 
VITA

\section{ALEJANDRO ANGEE}

Born, Medellin, Colombia

2003

B.A., Psychology

Florida International University

Miami, Florida

2005

National Association for the Practice of Anthropology Student Achievement Award

2006-2009

Research Assistant

Research Institute on Social and Economic Policy

Florida International University

Miami, Florida

2004-2006

Teaching Assistant

Department of Sociology and Anthropology

Florida International University

Miami, Florida

2007

National Association for the Practice of Anthropology Student Achievement Award

2009

Doctoral Candidate

Florida International University

Miami, Florida

2009

M.S., Comparative Sociology

Florida International University

Miami, Florida

2008-2009

Ethnographer

Chapin Hall Center for Children

University of Chicago

Chicago, Illinois

2009-2012

Instructor

Department of Social Sciences

Miami Dade College

Miami, Florida

2012-Present

Assistant Professor

Department of Social Sciences

Miami Dade College

Miami, Florida 


\section{PUBLICATIONS, REPORTS, AND PRESENTATIONS}

Angee, Alejandro and Cynthia S. Hernandez. "Seeds of Justice: Combating wage theft among South Florida's plant nursery workers." Paper published by the Research Institute on Social and Economic Policy, Florida International University, October 1, 2007. Accessed October 7, 2012. http://www.risep-fiu.org/2007/10/planting-seedsof-justice/

Angee Alejandro. "Planting Seeds: Community Action and Social Research Working Together to Combat Wage Theft in South Florida's Plant Nurseries." Presented at the American Anthropological Association Annual Meeting. Washington D.C., December 2, 2007

Angee, Alejandro. "Immigrant Construction Workers and Health and Safety: the South Florida Experience." Presented at the United Association of Labor Educators Conference. Washington D.C. March 8-10, 2007.

Angee, Alejandro. "Wage Theft in South Florida's Low-Wage Industries." Presented at Lat Crit XII. Miami Beach, FI. October 4, 2007.

Angee, Alejandro. "Reproducing Inequalities: Wage Theft in South Florida's Plant Nursery Industry." Race, Ethnicity, and Place Conference IV. Miami, FL. November 5-8, 2008.

Angee, Alejandro. "Without a Paycheck, Without a Voice: Wage theft in South Florida's Plant Nursery Industry." Paper accepted for presentation at the Society for the Study of Social Problems Annual Meeting. Boston, MA. July 31,2008.

Emily Eisenhauer, Alejandro Angee, Brianne Barclay and Jasney Cogua-Lopez. "Community Knowledge and Attitudes toward Refugees and Asylees in Miami-Dade and Broward Counties: An Analysis for the International Rescue Committee." National Association for the Practice of Anthropology Bulletin, Vol. 27 (2007) 224236.

Emily Eisenhauer, Yue Zang, Cynthia S. Hernandez, and Alejandro Angee. "Immigrants in Florida: Characteristics and Contributions." Research Institute on Social and Economic Policy, 2007. Report available at www.risep-fiu.org.

Nissen, Bruce, Alejandro Angee and Marc Weinstein. "Immigrant Construction Workers and Health and Safety: the South Florida Experience." Bruce. Labor Studies Journal, Vol. 33 (2008) 48-62.

Smith, Jeanette and Alejandro Angee. "Wage Theft: Morality and Economics in South Florida." Presented with Jeanette Smith at the Society for Applied Anthropology Meeting. Merida, Mexico. March 24-27, 2010. 